$$
\begin{aligned}
& \text { منهــج الإمـام المحاسبـي } \\
& \text { في } \\
& \text { الوصــول لليقـين } \\
& \text { إعراو } \\
& \text { مدرس العقيدةوالفلسفة } \\
& \text { بكليةأصول الدني والدعوة الإسلامية بطنطا }
\end{aligned}
$$




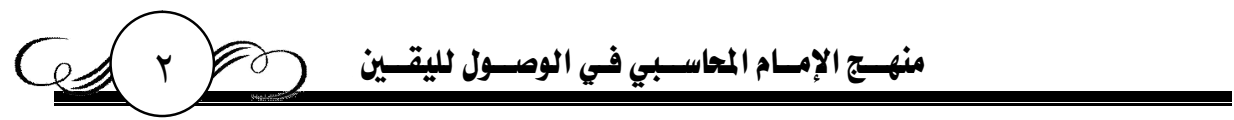

\section{ملخـص البحــث}

هذا البحث يدور حول شخصية سطرت معالم المنهج التجريبي بصورة

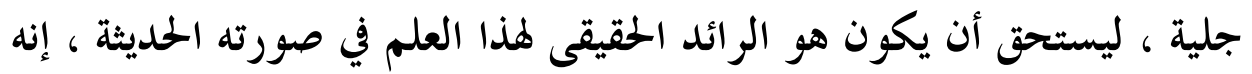
الإمام الحارث بن أسد الخاسبي ؛ الذي استطاع أن يضع القواعد السليمة

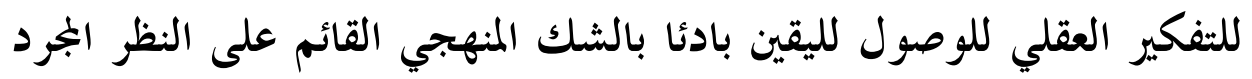

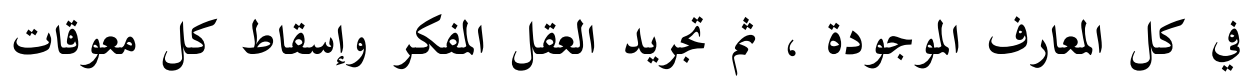
الوصول للحقيقة عنه حتى يتسنى له صحيح النظر ، ثم يقوم بالاستقراء

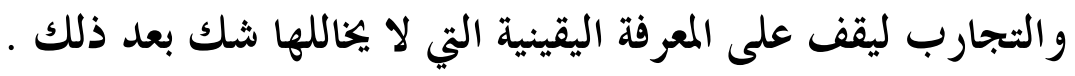

This research revolves around a character who has clearly outlined the features of the experimental curriculum, to deserve to be the true pioneer of this science in its modern form. It is Imam Al-Harith bin Asad al-Muhasbi, who was able to establish sound rules of mental reasoning to reach certainty beginning with the systematic doubt based on abstract consideration in each Existing knowledge, then abstract the thinking mind and drop all obstacles to reach the truth so that it is valid to consider, and then extrapolates and experiments to stand on the .knowledge of certainty, which is beyond doubt after that 


\section{بسماللهالرحم:الرحيم}

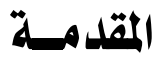

الحمد لله رب العالمين ، له الملك وله الحمد وهو على كل شيء قدير ـ والصلاة

والسلام على أشرف خلق الله أجمعين سيدنا محمد وعلى آله وصحبه أبمعين .

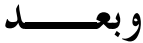

فهذا بحث يدور حول شخصية لها بالغ الأثر في الثقافة الإسلامية ، والفكر العالمي

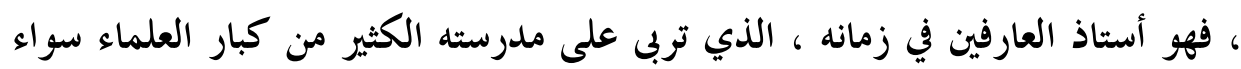
بالمشاهدة أو بقراءة الكتب ، والذي خاض غمار البحث في النفس الإنسانية ، وقام

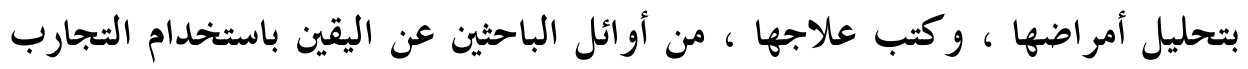
الممزوجة بالنظر العقلي الشرعي ، حبر زمانه معرفة وسلوكا ، أشد الناس محاسبة لنفسه الثها حتى صارت الخحاسبة لقبا له دون غيره من العلماء . إنه الحارث بن أسد الخاسبي صاحب التآليف الكثيرة والمتنوعة ، والنظريات

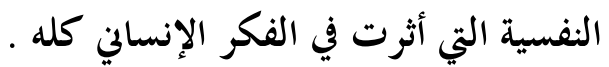

وهذا البحث - بفضل الله تعلى - يتناول جزءا من فكر هذا العلم ، وهو منهجه

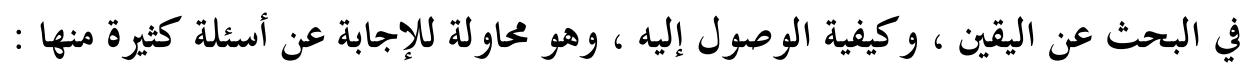

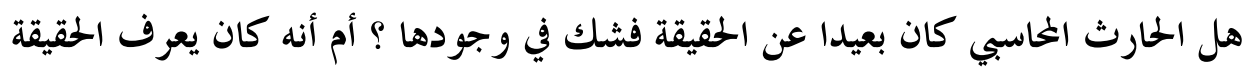

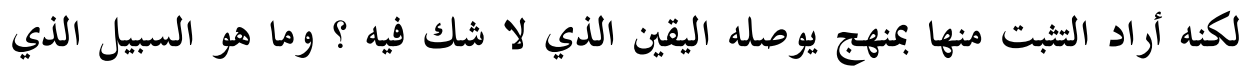

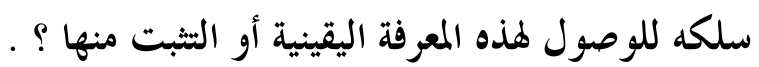
كل هذه الأسئلة وغيرها هي مدار هذا البحث بإذن الله تعلى ، و الذي أرجو من الله تعالى فيه التوفيق والقبول . ملوه الاسئل 


\section{منهــ الإمسام المحاسـبي في الوصسول لليقـين}

أهمية البحث

ترجع أهمية هذا البحث في بيان نظرة المسلمين الأوائل لدينهم ، و كتابم ، وللعقل الذي استخدموه في الوصول للمعارف المختلفة ، مهتدين هُهدي القرآن الكريم الذي حضهم على ذلك، وكيف رتبوا أفكارهم العقلية ترتيبا دقيقا للوصول للصواب، مع لهابع عدم إهمال الجانب الديني ، سابقين بذلك كل النظريات والمناهج الحديثة في الفلسفة ،

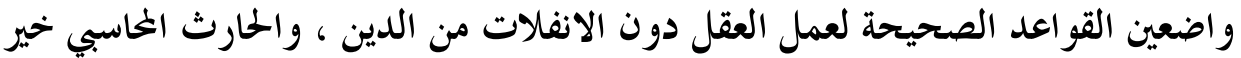

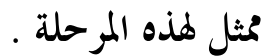
بل يمكن القول : إنه رائد هذه المدرسة الشرعية العقلية الروحية الذي أثر تأثيرا مباشرا وغير مباشر في كل من تكلموا في المنهج التجريب من بعده . وقد اهتم الباحثون بدراسة الفكر الصوفي والعقلي المتعلق بالإمام الخحاسبي ، وتنوعت الدراسات الحاصة عنه ما بين كتب مستقلة ، وبحوث علمية ، ومن أشهر الذين

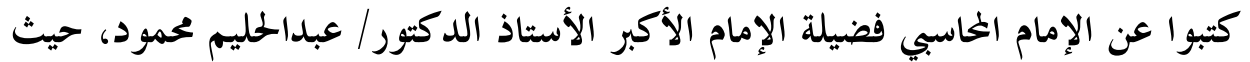
حقق كتاب الرعاية لحقوق الله ، وألف كتاب أستاذ السائرين ، وقد عني فيه بدراسة الإنا

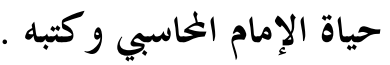
وقدم الدكتور حسين القوتلي دراسة عن العقل ومتزلته عند الإمام الخاسبي في بداية تحقيقه لكتاب مائية العقل للإمام الخاسبي . ولأستاذ الدكتور / فتحي الزغبي بحث عن خصائص التصوف عند الإمام الخاسبي بعنوان : خصائص التصوف في القرنين الثالث والرابع الهجريين من خلال الخاسبي

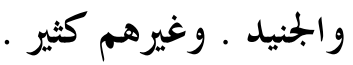

لكن هذه الكتب وغيرها لم تتحدث بصفة مستقلة عن منهج الإمام الخاسبي في الوصول لليقين . فكان هذا البحث لبيان هذه الجزئية في فكر الإمام الخاسبي ، أسأل الله تعالى التوفيق والسداد والمعونة على إتمامه بصورة علمية مناسبة . 
منهـج الإمسام المحاسبي في الوصسول لليقسين

\section{منهج البحث}

يعتمد هذا البحث - بفضل الله تعالى - على المنهج التحليلي لكتب الحارث

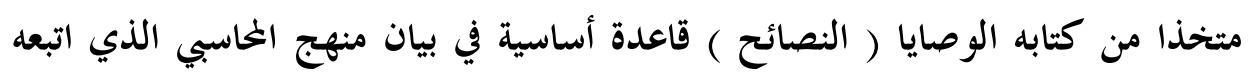

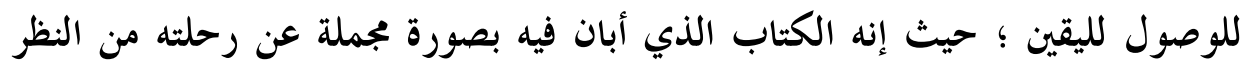

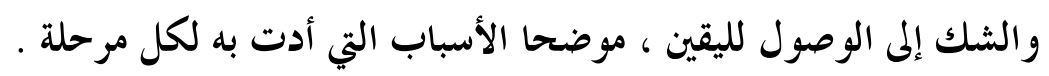

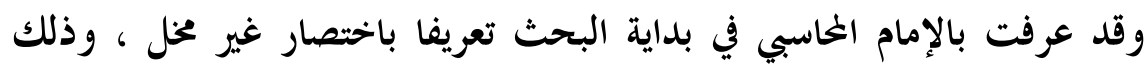

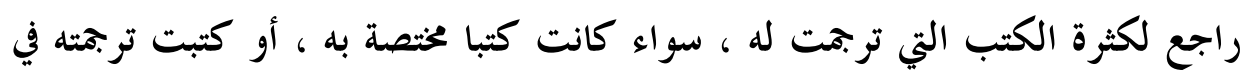

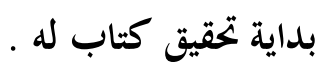

وقد تم تقسيم البحث ليتناول المسائل الآتية :

أولا : التعريف بمفردات البحث : ( الإمام الخاسبي ، اليقين ) .

ثانيا : منهج الإمام الخاسبي في تحقيق اليقين .

أسأل الله تعالى التوفيق والسداد والتبول . 


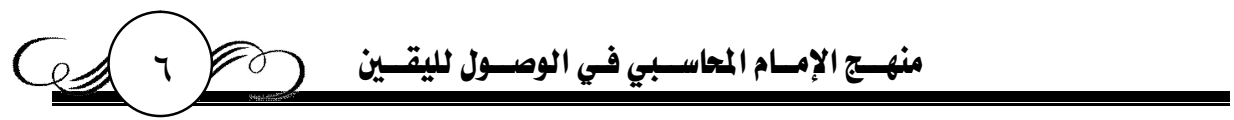

التصريـف ببفرداتالبحـث 


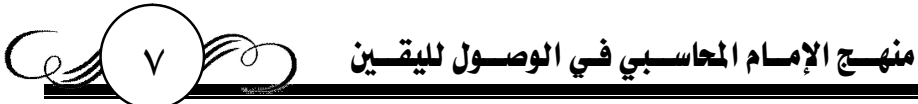

\section{أولا : التعريف بالحارث الخاسبي}

أبو عبدالله الحارث بن أسد الخحاسبي ، علم العارفين في زمانه ، وأستاذ السائرين

الجامع بين علمي الباطن و الظاهر (1)

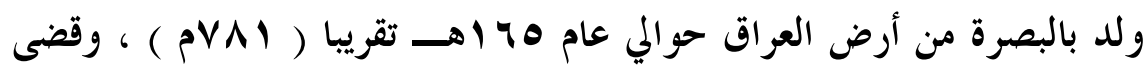

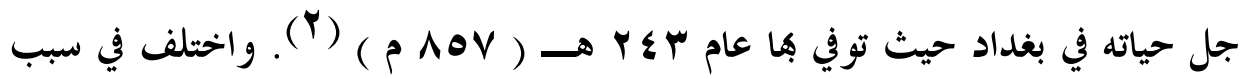

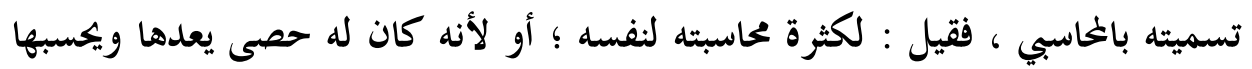
حال الذكر ، وقيل لغير ذلك (بّ). صحب الإمام الشافعي ، وقيل بل عاصره فقط (\&)، ونفى ابن الصلاح صحبته للإمام الثافعي(•) تلاميذه :

تتلمذ على علم الخاسبي خلق كثير ، بالتعليم المباشر وغير المباشر ، فهو أستاذ

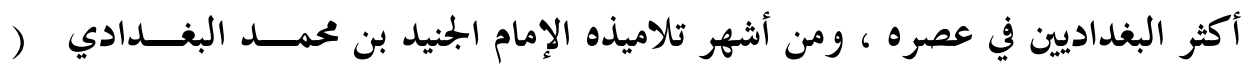

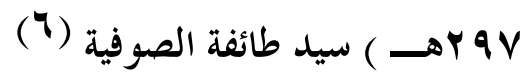

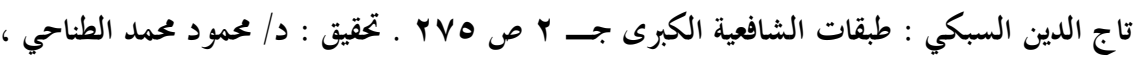

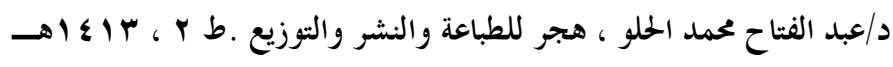

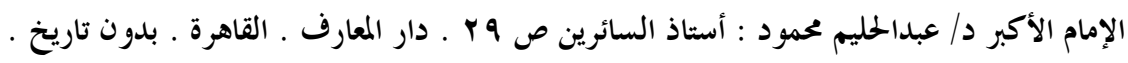

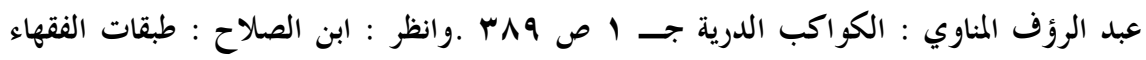

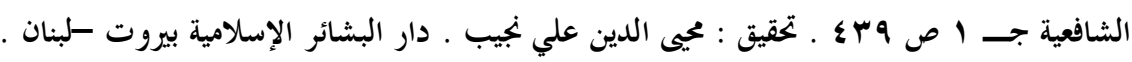
. $199 r$

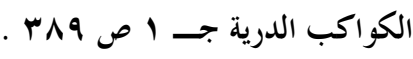

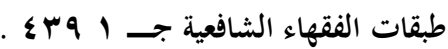

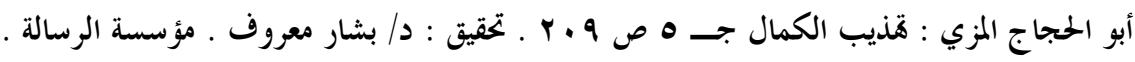

بيروت -لبنان . ط1 . . ـ اهــ، . .91 19 م . 


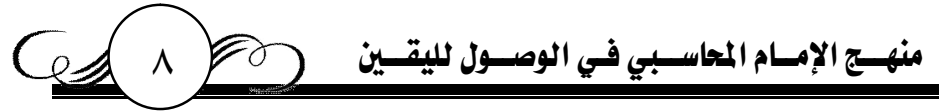

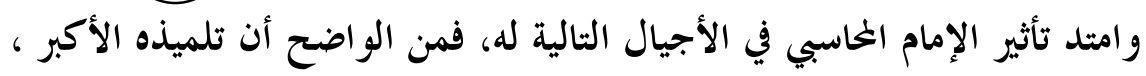

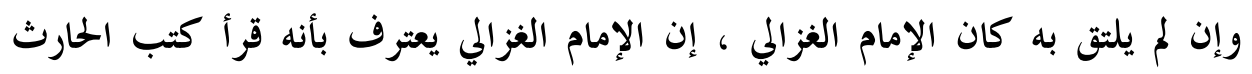

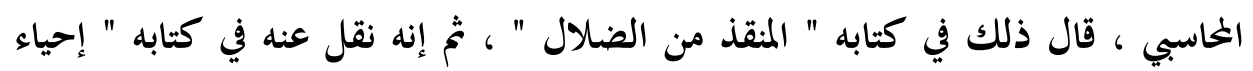

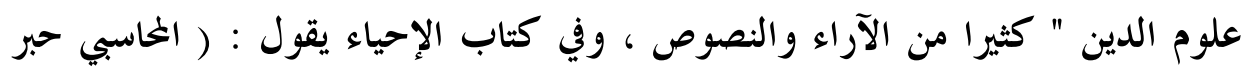

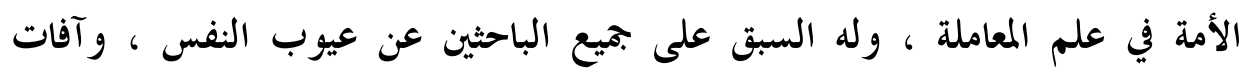
الأعمال وأغوار العبادات ، و كلامه جدير بأن يككى على وجهه ) (1). حياتسه :

كان مولد الخاسبي في مغرب خحلافة المهدي العباسي ، وهو من أوائل الحلفاء

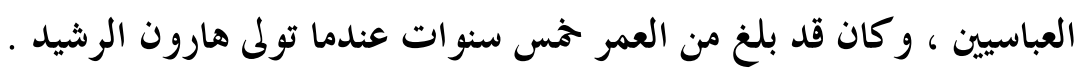
وكانت الأمة الإسلامية حينئذ غنية بالمفكرين البارعين ، وخاصة في رحاب

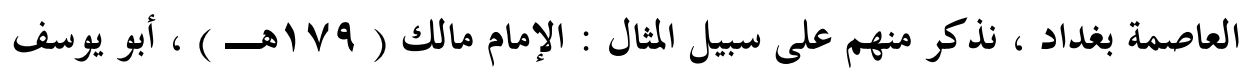

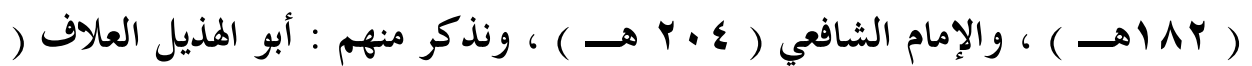

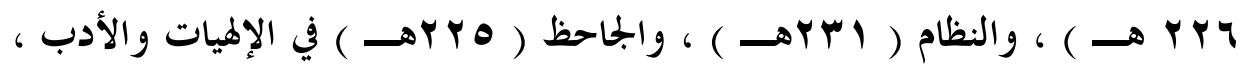

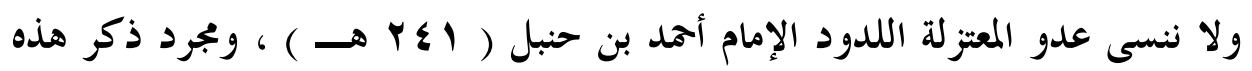

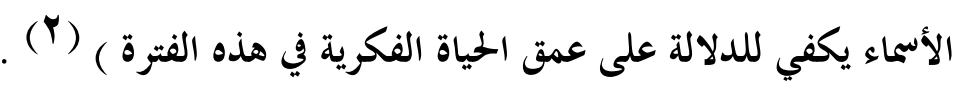
( ولم يهتم الخاسبي بالعلوم المادية أو العلوم البحتة التي ليس من ورائها هذيب أو

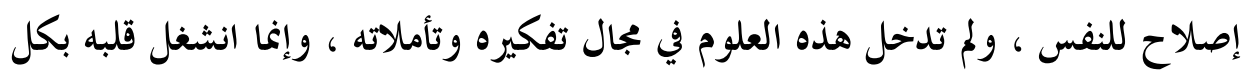

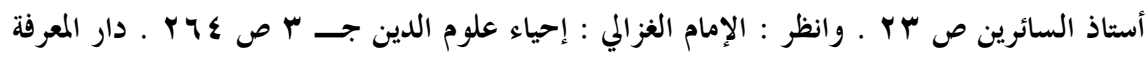

$$
\begin{aligned}
& \text { ـ بيروت -لبنان . بدون تاريخ . }
\end{aligned}
$$

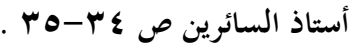




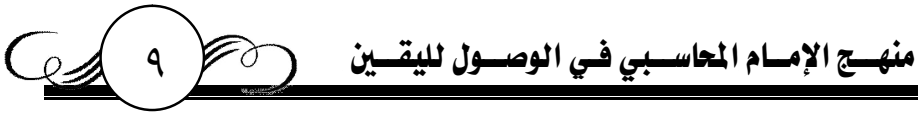

ما كان من الأمور التي تتعلق بالبيئة الدينية ) ( ( )

وقد نشأ الخاسبي في جو مليء بالاختلافات السياسية والدينية والعلمية ، فكان زمانه مليئا بالجدال في مسائل العقيدة بين أهل الححديث من جهة ، وبين المعتزلة من جهة أخرى ، و كانت الخلافات السياسية بين العرب والفرس ، يريد كل فريق منهم أن يكون له اليد العليا في أمور الدولة ، واحتدمت بسببه المؤامرات ، و والدسائس في بلاط الخلفاء ، كذلك كان هناك صراع الثيعة للقضاء على الخخلافة القائمة نفسها ، وأما في الجال الديني فالأمور أكثر تعقيدا ، كان المعتزلة يريدون السيطرة ، و كان أهل السنة يريدون السيطرة ، و كان الحوارج يريدون السيطرة ، كما كانت كل العقائد الدينية التي بدت و كأن الإسلام قضى عليها تتزين في أثواب جديدة ، وتصبو هي الأخرى إلى العودة للحياة ، كل ذلك كان يغلي في مرجل المناقثة والخصام والجدل ، وانتهل وانتهزت مختلف الفرق كل فرصة مواتية ، وجرت الخليفة نفسه إلى التدخل في فتنتها ، و كانت هناك

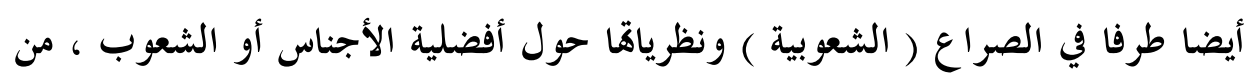

$$
\text { الأفضل ومن الأكفأ : العرب أم اللا عرب ؟ (ب). }
$$

وهذه الأمور جميعها كانت سببا مباشرا في تحول فكر الخاسبي للبحث عن اليقين ، وتحصيل الحقيقة اليقينية في المعرفة في إطار الكتاب والسنة المطهرة ، دون التأثر بأي ثقافة خارجية عن الإطار الإسلامي في عصره أو قبل عصره ، فلم يؤثر عن الخاسبي أنه تأثر بأي فلسفة أو ديانة منتشرة ، بل كان علمه ونظره نابعين من الكتاب والسنة متأثرا

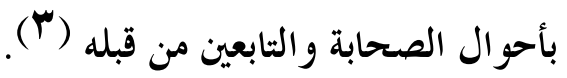

$$
\begin{aligned}
& \text { (1) (1) نفسه ص ק. } \\
& \text { أستاذ السائرين ص إع-ب ع بتصرف . }
\end{aligned}
$$

فند الإمام الأكبر الدكتور / عبدالحليــم محمـــود الشبهات التي قيلت عن تأثر الإمام الخاسبي خاصة 


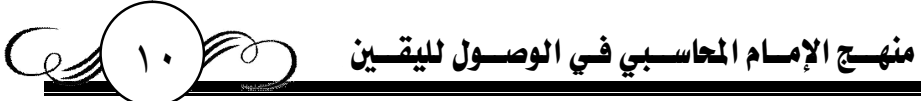

وقد تعددت الروايات في بيان ورع الخاسبي ، وزهده ، وأكثر ما يعنينا منها ما رواه الإمام الجنيد ( أن الحارث كان كثير الضر ، واجتاز بي يوما وأنا جالس على بابنا ، فرأيت على وجهه زيادة الضر من الجوع ، فقلت له : يا عم لو دخلت إلينا نلت من شيء عندنا ، قال : أو تفعل ؟ قلت : نعم وتسربي بذلك وتبرلي ، فدخلت بين يديه ، ودخل معي ، وعمدت إلى بيت عمي ، و كان أوسع من بيتنا لا يخلو من أطعمة فاخرة لا يكون مثلها في بيتنا سريعا ، فجئت بأنواع كثيرة من الطعام ، فوضعته بين يديه ، فمد يده وأخذ لقمة فرفعها إلى فيه فرأيته يلو كها ولا يزدردها ، فوثب وخرج وما كلمني ، فلما كان الغد لقيته فقلت : يا عم سررتني ثم نغصت علي ، قال : يا بني أما الفاقة فكانت شديدة ، وقد اجتهدت في أن أنال من الطعام الذي قدمثه إلي ، ولكن بيني وبين الله علامة إذا لم يكن الطعام مرضيا ارتفع إلى أنفي منه زفرة فلم تقبله نفسي ، فقد رميت

تلك اللقمة في دهليز كم وخرجت ) (1) مؤ لفاته :

تعددت مؤلفات الخاسبي ، وبلغت من الكثرة ما يربوا على المائتي مؤلف ، فلإمام الخاسبي كتب كثيرة في الزهد وأصول الديانات ، والرد على المخالفين من المعتزلة و الر افضة وغير هما ، و كتبه كثيرة الفوائد جمة المنافع (ب)، ومنها : آداب النفوس ، شرح المعرفة ، المسائل في أعمال القلوب والجوارح ، والمسائل في الزهد ، رسالة البعث

= و التصوف الإسلامي عامة بأي أثر خارجي ، موضحا أن هذه الشبهات ليست صحيحة في الواقع ،

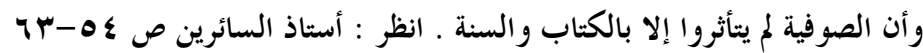

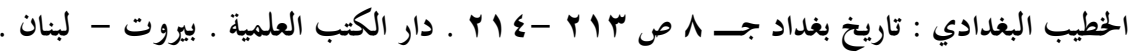

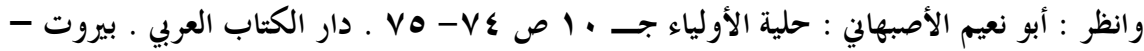

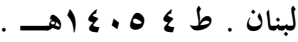

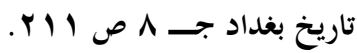




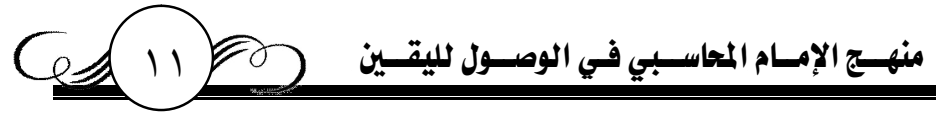

والنشور ، مائية العقل ومعناه واختلاف الناس فيه ، الرعاية لحقوق الله ، الحلوة والتنقل

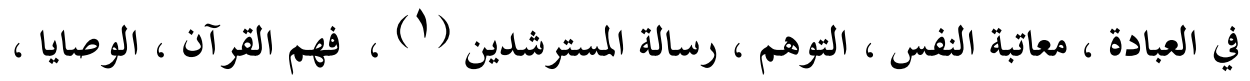

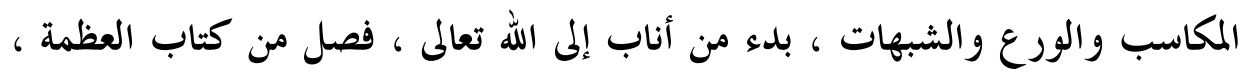

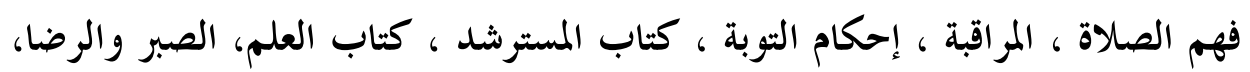

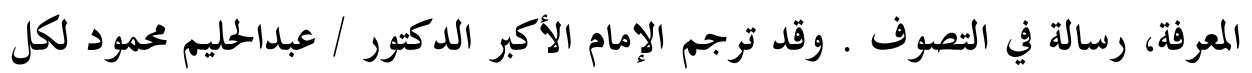

كتاب من هذه الكتب مع ذكر موضوع كل كتاب في كتابه أستاذ السائرين (r). وثمت كتبا أخرى مفقودة للإمام الخاسبي مثل : كتاب التنبيه ، وكتاب أخلاق

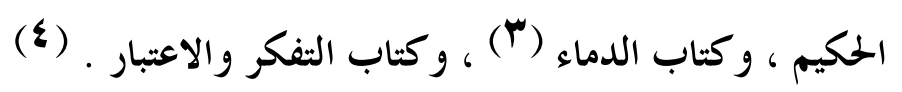

وللإمام الخاسبي طريقة في التأليف لم تكن شائعة أو منتشرة في زمنه ، عمل فيها

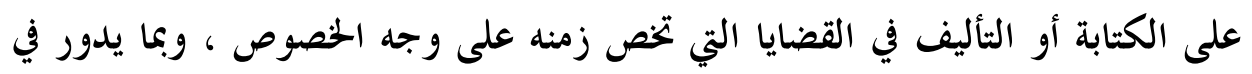

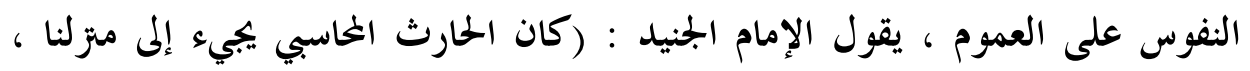

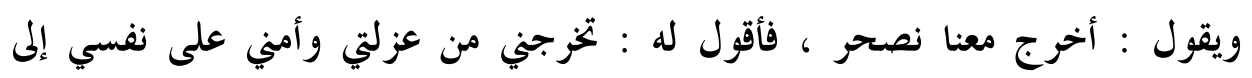

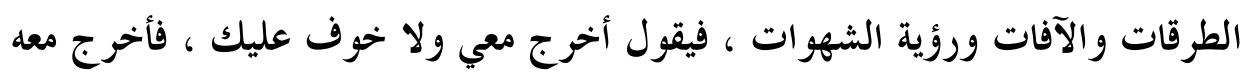

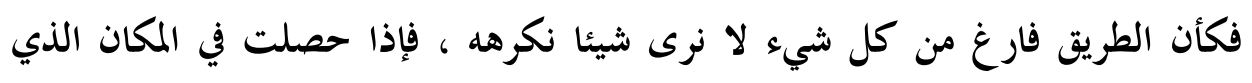

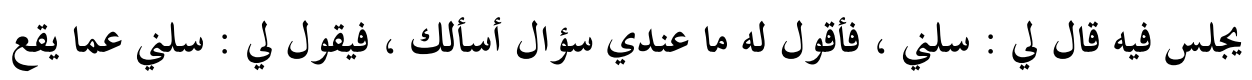

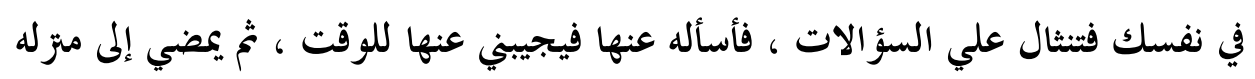

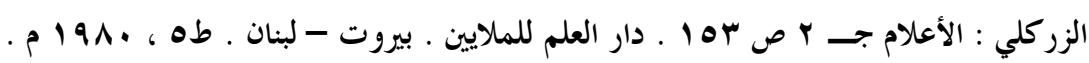

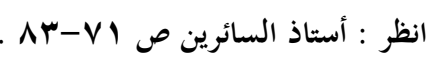

ذكر الخطيب البغدادي وابن الصلاح وغيرهما نسبة هذا الكتاب للإمام الخاسبي عند ترجمتهم له .

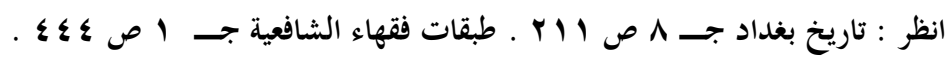

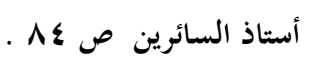


منهـج الإمسام المحاسببي في الوصـول لليقسين

\section{فيعملها كتبا ) (1)}

وهذه الطريقة تحرك العقل والوجدان نحو ما يثار من أسئلة تتعلق بالمسائل العقلية

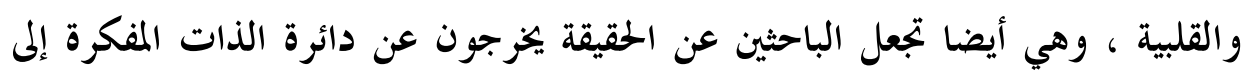

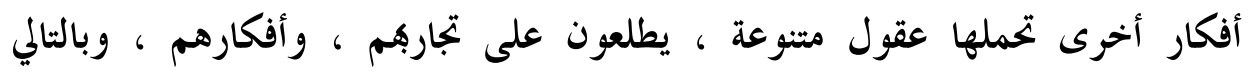

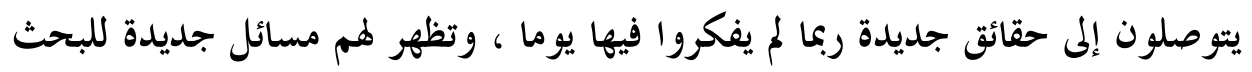

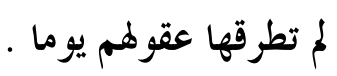

\section{الترتيب التاريخي لمؤلفات الخاسبي :}

قام بمحاولة ترتيب كتب الإمام الخاسبي تاريخيا جل العلماء الذين تناولوه بالدراسة

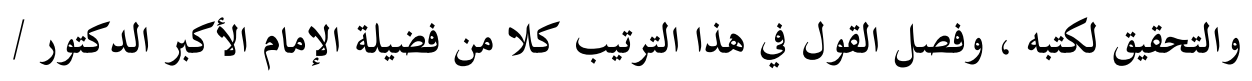

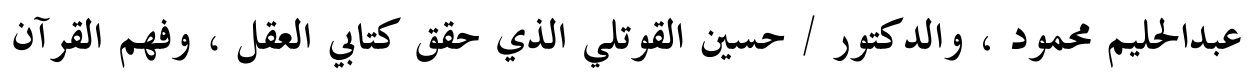

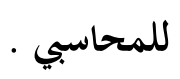

أما فضيلة الإمام الأكبر : فيرى صعوبة ترتيب كتب الخاسبي ترتيبا تاريخيا ؛

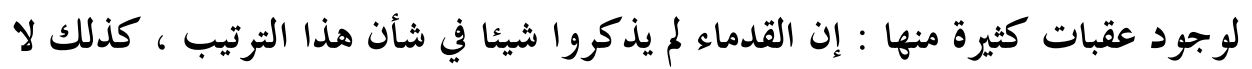

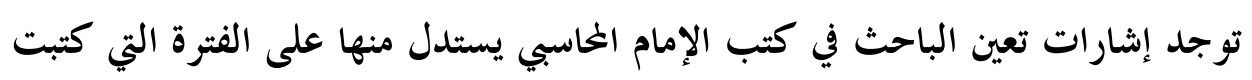

فيها (r)

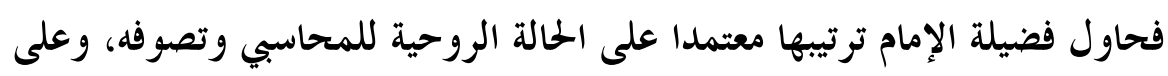

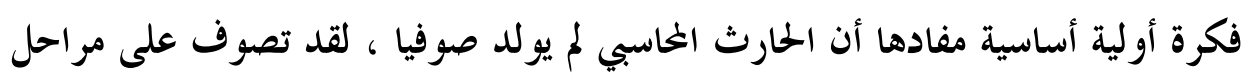

: نزعة صوفية تقوى شيئا فشيئا ، ثخ الوصول إلى قمم التصوف بعد سنين طويلة (ب).

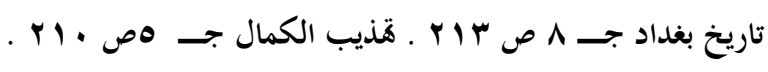

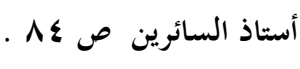

$$
\begin{aligned}
& \text { نفسه ص م1. }
\end{aligned}
$$




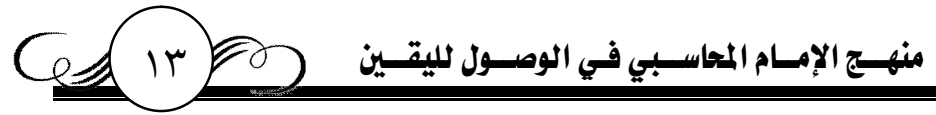

ويرى الإمام الأكبر أن الخاسبي سار في بداية حياته كمؤلف على الأساليب

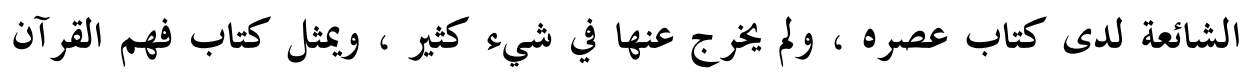

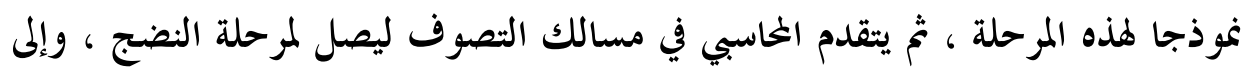

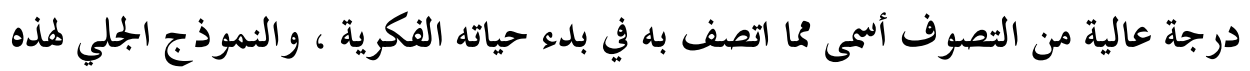

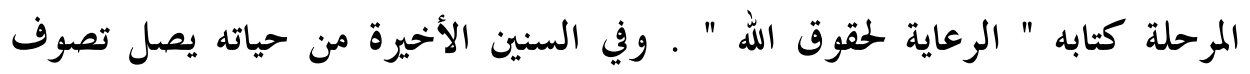
الخاسبي إلى أعلى قممه ، و النموذج الذي يمثل كتبه حينئذ هو كتاب " الوصايا " (1 ). فالإمام يربط ترتيب الكتب بمراحل تصوف الإمام الخاسبي ، وترقيه في مراحل السلوك المختلفة ، ليكون عنده ثلاث مراحل : مرحلة البداية ، ثم مرحلة التحليل

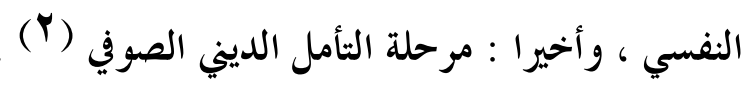
وعلى نفس النهج سار الدكتور القوتلي ، فإنه يرتب الكتب بناء على مراحل

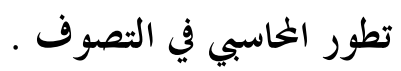
لكنه يخالف الإمام الأكبر في التقسيم الزمني، وبالتالي الترتيب التاريخي للكتب ،

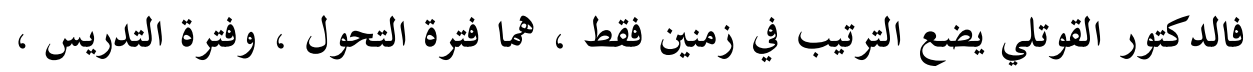

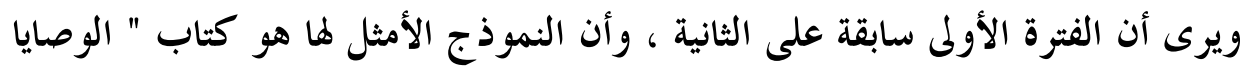
" ولمثل قوله ذهب الشيخ / عبدالقادر أحمد عطا (†)" وكتب فترة التحول عند الدكتور القوتلي متنوعة، وقد رتبها على النحو التالي :

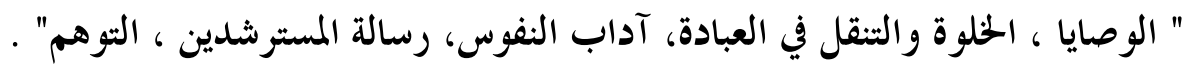

$$
\begin{aligned}
& \text { نفسه ص 01- צ^. } \\
& \text { نفسه ص AV . }
\end{aligned}
$$

انظر : عبدالقادر عطا : مقدمة كتاب آداب النفوس للمحاسبي ص ؟Y .مؤسسة الكتب الثقافية .

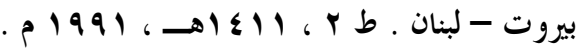




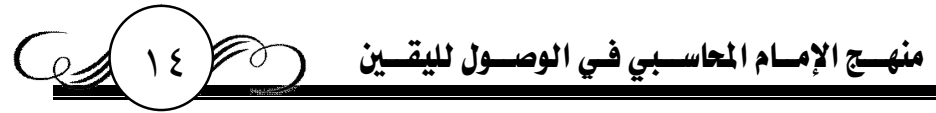

المرحلة الثانية : فترة التدريس : يغلب في أولها الزعة الكلامية المختلطة بالتصوف

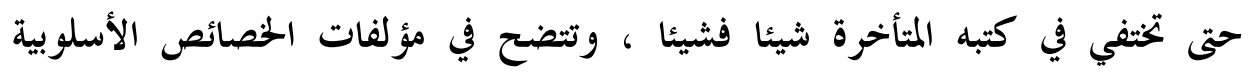

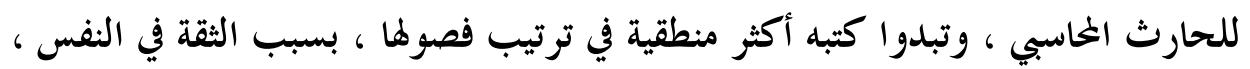
والاعتداد الكبير بالعقل المؤمن ، وترتيب مؤلفات هذه الفترة على النحو التالي : مائية

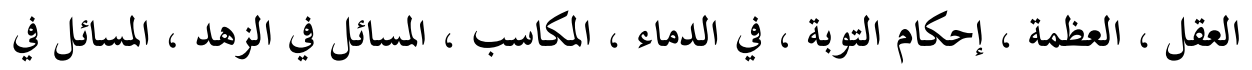

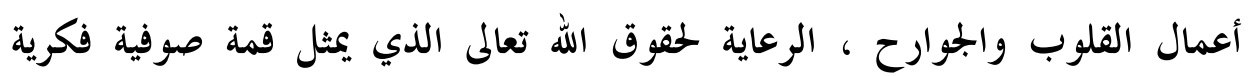

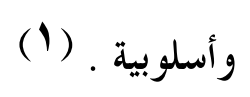

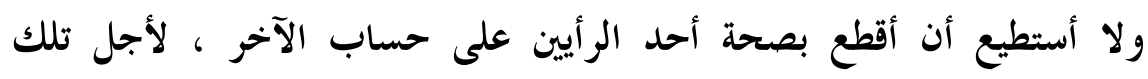

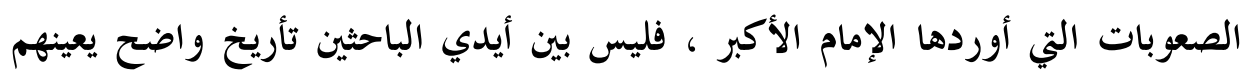
على ترتيب هذه الكتب ترتيبا زمنيا. لكن الذي يعني هذا البحث هو الترتيب الفكري والمنهجي لهذه الكتب ، ويعتبر

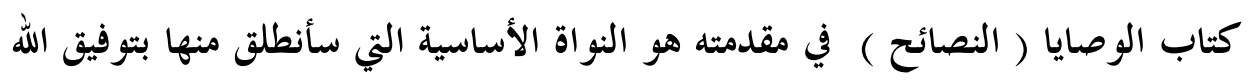

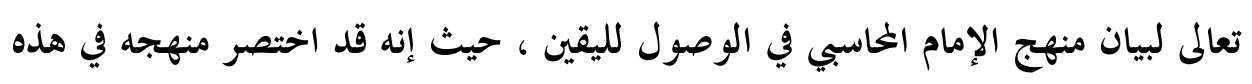

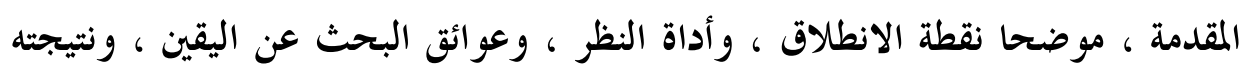

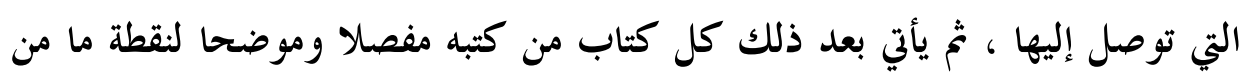

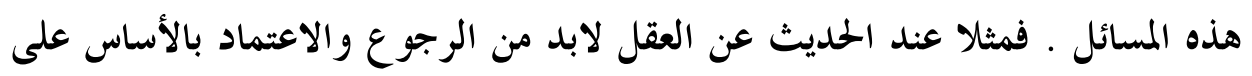

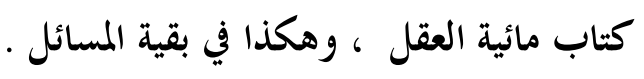


ثانيا : التعريف باليقين

اليقين يطلق على العلم وإزاحة الشك ، وتحقيق الأمر ، وقد أيقن يوقن إيقانا ، فهو موقن ويقن ييقن يقنا فهو يقين ، واليقين نقيض الشك ، و العلم نقيض الجهل ،

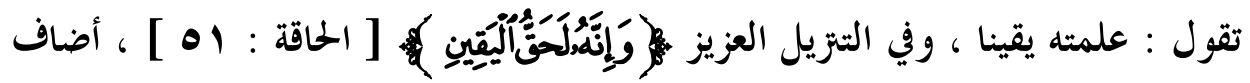
الحقى لليقين ، وليس هو من إضافة الشيء إلى نفسه ؛ لأن الحقى هو غير اليقين ، إنما هو

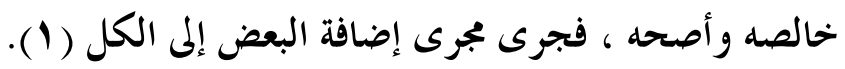
وفي الاصطلاح : اعتقاد الشيء بأنه كذا مع اعتقاد أنه لا يمكن إلا كذا مطابقا

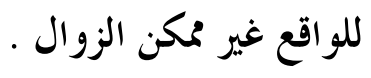
والقيد الأول : جنس يشتمل على الظن أيضا ، والثاني : يخرج الظن ، والثالث: يخرج الجهل ، والرابع : يخرج اعتقاد المقلد المصيب . وعند أهل الحقيقة : رؤية العيان بقوة الإيمان لا بالحجة والبرهان، وقيل بمشاهدة الغيوب بصفاء القلوب وملاحظة الأسرار بمحافظة الأفكار . وقيل هو طمأنينة القلب على حقيقة الشيء ، يقال : يقن الماء في الحوض إذا استقر فيه . - n وقيل : اليقين رؤية العيان ، وقيل : تحقيق التصديق بالغيب بإزالة كل شك وريب ـ وقيل : اليقين نقيض الشك ـ وقيل : اليقين رؤية العيان بنور الإيمان. وقيل : اليقين ارتفاع الريب في مشهد الغيب . وقيل : اليقين العلم الحاصل بعد

(Y) (ب) (ب)

$$
\text { ابن منظور : لسان العرب جـ r ا ص OV \& ـ دار صادر - بيروت .لبنان . }
$$

انظر : الجرجاني : التعريفات ص بrس . تحقيق : إبراهيم الإبياري ـ دار الكتاب العربي ـ بيروت - 


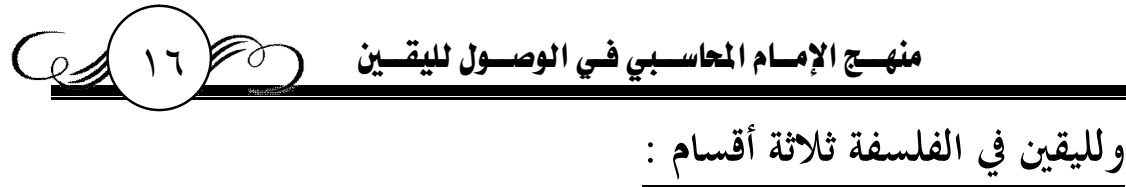

الأول : اليقين الواقعي أو الطبيعي : وهو الاعتقاد الجلازم المتعلق بموضوعات

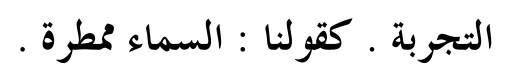

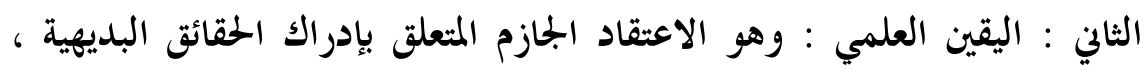

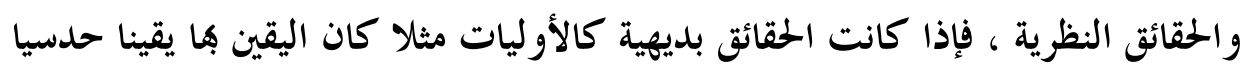

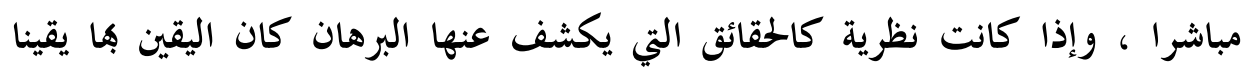

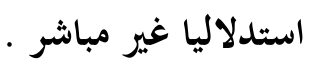
الثالث : اليقين الأخلاقي : اقتناع المرء بأنه يستطيع أن يتخذ إزاء ما يعتقد حقيته

قرارا عمليا مو افقا ، وإن كان هذا الاقتناع لا يتناف مع إمكان الخطأ ( (1). واليقين عند الصوفية على ثلاث مقامات : يقين معاينة : وهذا لا يختلف خبره ،

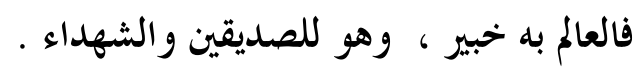

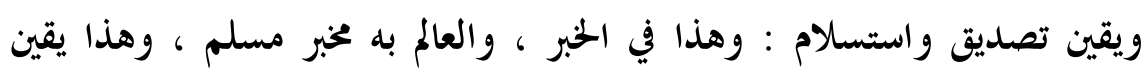

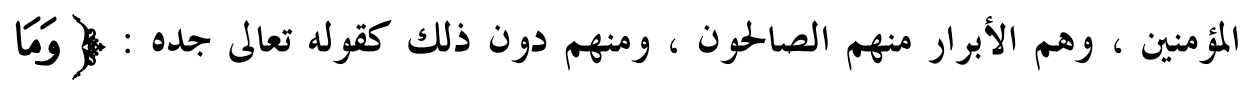

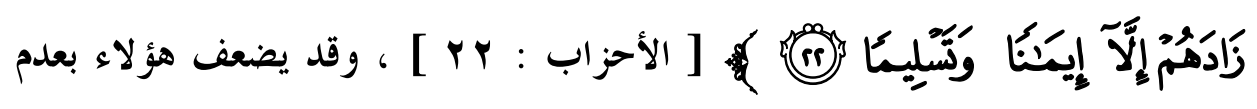

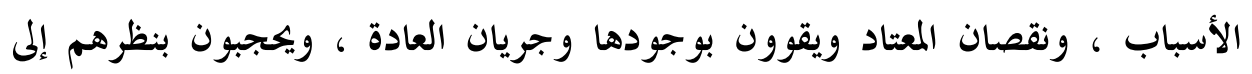

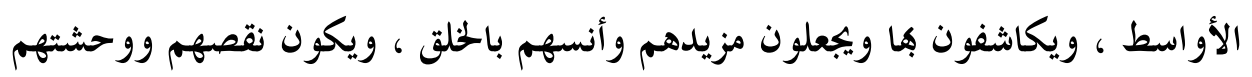
بفقدهم، ويكون من هؤلاء الاختلاف ويتلوّنون بالخلاف لتلوين الأشياء وتغيرها نقصهيا.

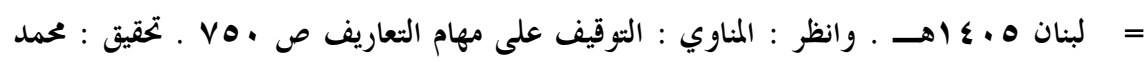

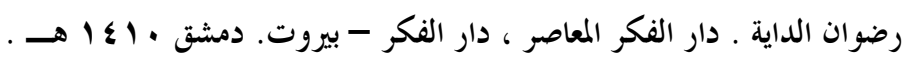

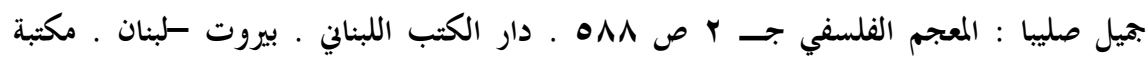

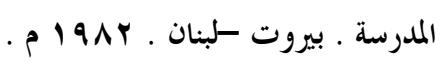




\section{منهـج الإمسام المحاسـبي في الوصسيول لليقسين}

المقام الثالث من اليقين : وهو يقين ظن يقوى بدلائل العلم والخبر ، وأقوال

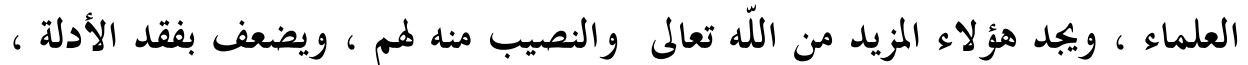
وصمت القائلين ، وهذا يقين الاستدلال وعلوم هذا في المعقول وهو يقين المتكلمين من عموم المسلمين من أهل الرأي وعلوم العقل والقياس والنظر ، و كل موقن باللّه تعالى فهر على علم من التوحيد والمعرفة ، ولكن علمه ومعرفته على قدر يقينه ، ويقينه من نحو صفاء إيمانه ، وقوّته و إيمانه على مقتضى معاملته ورعايته ( (1).

\section{تعريف اليقين عند الإمام الخحاسبي}

يرى الإمام الخحاسبي أن اليقين ضد الشك ، وأنه مرحلة أخيرة في المعرفة ، بعد أن يتحقق بها العبد لا بد أن يعمل عليها وألا يتركها ، وقدد تنوعت عبارات الإمام الخاسبي في بيان ذلك ، حيث ذكر في أكثر من موضع من كتبه اليقين كمرحلة أخيرة في المعرفة ،

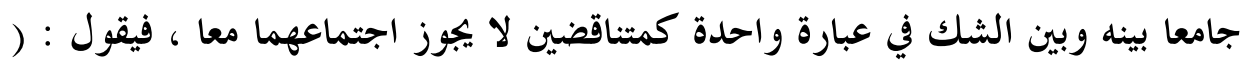
إن أصل الشكر أن يعرف العبد أن ما به من نعمة فمن الله بقلبه ، علم يقين ، لا تخالطه الشكوك ) (ب) ) . وينصح محاوره بالعمل على اليقين وترك الشك قائلا : (فاعمل على

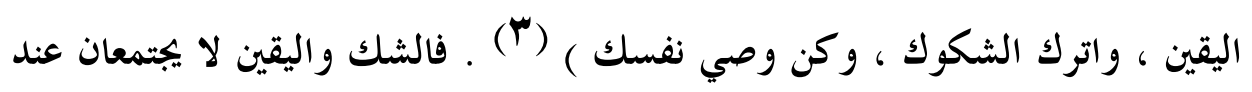
الخاسبي ، فالشك عذاب لا يذهب إلا باليقين ، ولا يتحقق اليقين إلا بالمعرفة الصحيحة ،

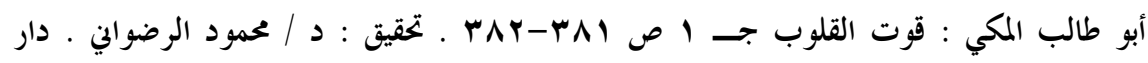

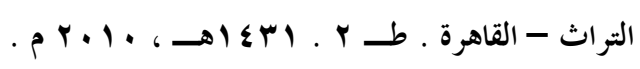

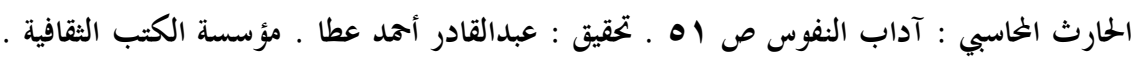

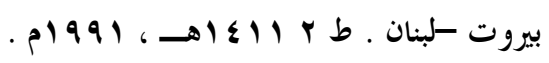

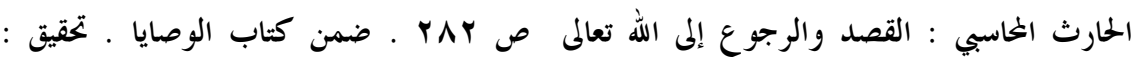

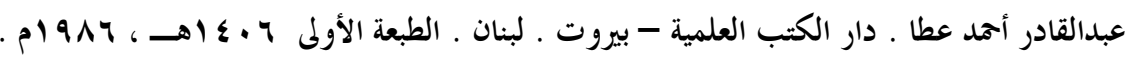




\section{منهـج الإمسام المحاسببي في الوصسول لليقسين}

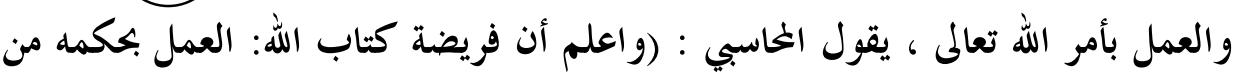

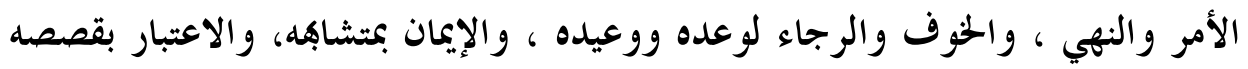

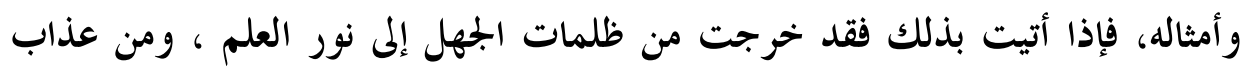
الشك إلى روح اليقين ) ( () . وقد استخدم الإمام الخاسبي هذا المركب في كلامه كثيرا ، فقد بمع بين كلمتي رَوْح ، و كلمة اليقين في أكثر من موطن (r) ، واستبدلها بكلمات

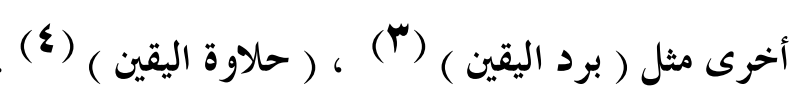

ويتحقق صدق اليقين عند العمل ( بالإيمان وبالعقل ، وبالمعرفة وحسن التدبير في

ظاهر أمر العبد وباطنه ) (o)

وبذلك يعرف الإمام الخاسبي اليقين في مرحلته الأخيرة بأنه : ( نور يجعله الله تعلى المي

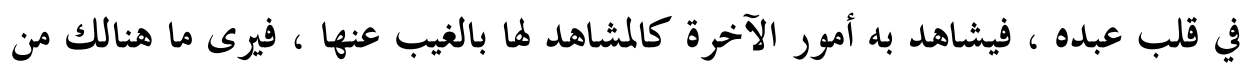

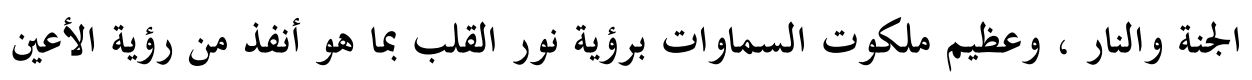

(†) (لمشاهدة الدنيا )

الخاسبي : رسالة المسترشدين ص رب . تحقيق : عبدالفتاح أبو غدة ـ دار السلام . حلب - سوريا .

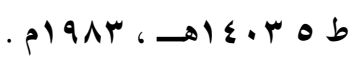

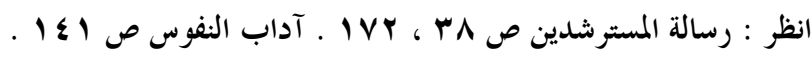

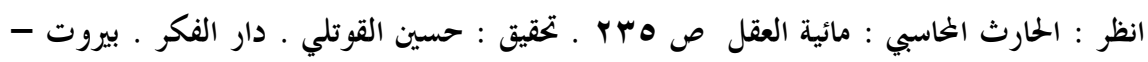

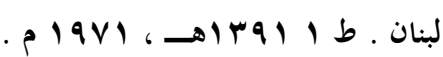

$$
\text { آداب النفوس ص ץ آد. }
$$

الإمام الخاسبي : الحلوة والتنقل في درجات العابدين ص كVV . تحقيق : إغناطيوس عبده فكري . مجلة المثرق .عدد رقم ع أكتوبر 1900 م ـ المطبعة الكاثوليكية . 


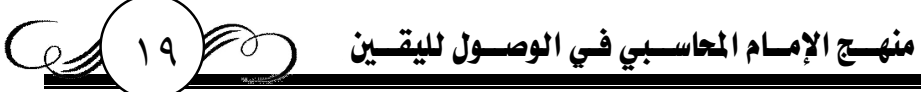

فالإمام الخاسبي يرى أن اليقين ضد الشك ، وأن الوصول لليقين يتم بالعقل كآلة للاستدلال الظاهر على المعارف ، وبالإيمان الناتج عن معرفة وتعقل وتوفيق من الله تعلى الى ـ وهذا ما سوف يفصله البحث بتوفيق الله تعلى في الصفحات القادمة . 


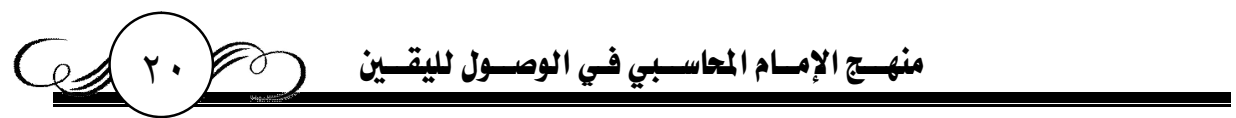

منهـج الإمامامداسلبي في تحقيق اليقـين 


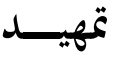

يؤمن الإمام الخاسبي بوجود معرفة يقينية ، أراد البحث عنها ، أو التيقن والتثبت منها ، وقد أعلن عن المراحل التي سلكها في سبيل الوصول لليقين مجملة تارة ومفصلة أخرى .

وأحاول من خحلال قراءة ما كتبه الإمام الخاسبي ، حسب المنهج المعلن عنه في

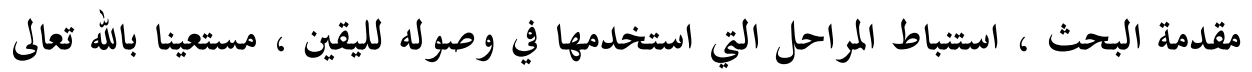
طالبا منه التوفيق والسداد. وهذه المراحل تتلخص فيما يلي :

المرحلة الأولى : الشك القائم على النظر الجرد ( ().

يرى الخحاسبي أن الشك مرحلة لابد منها في البحث عن الحقيقة ، وأن هاجس الشك يصيب الباحثين في اليقين ، وأن الشك أسبق للقلوب من اليقين وأوجد ؛ لأن الأن

$$
\text { اليقين أعز مطلبا وأقل وجودا (Y). }
$$

وأن العاقل هو من يعمل على التخلص من الثك بأدوات عقلية مناسبة ، ثم يأتيه

احترت كثيرا عند اختيار هذا العنوان كخطوة أولى في منهج الخاسبي للوصول لليقين ، خاصة أن لفظ الشك لم يستخدمه الخاسبي صراحة في بدايات حديثه عن منهجه في كتابه الوصايا ، و وإنما استخدم

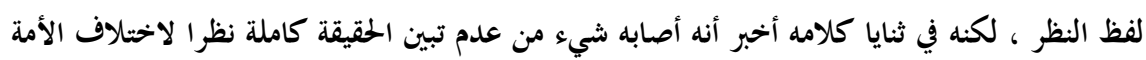

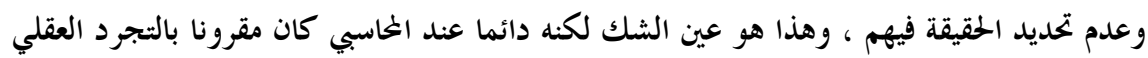

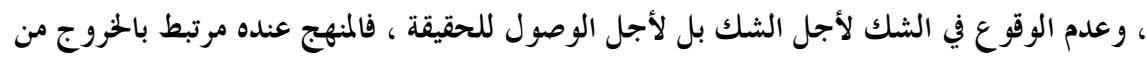

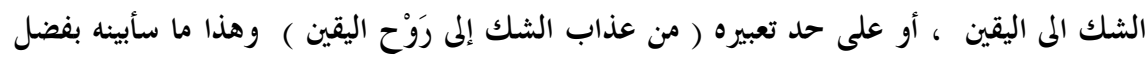

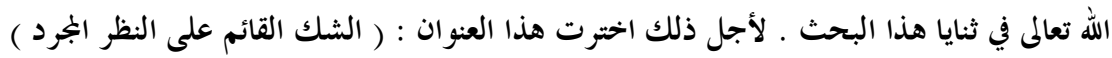

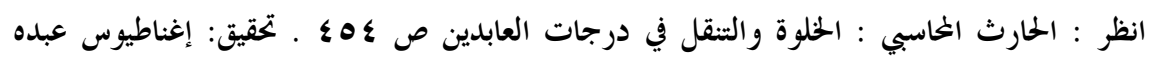
خليفة . مجلة المشرق . عدد رقم ع أكتوبر 1900 م م . 


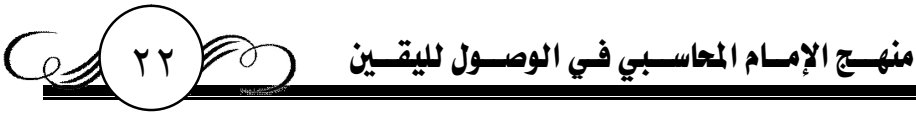

لطف الله تعالى ليخلصه من هذا الشك جملة وتفصيلا ( (1) ، وغيره يظل في الباطل إذا لم يشك فيما هو عليه ويتهم نفسه (Yَ) ، فالشك سبيل للنظر في المعارف ، والتثبت من

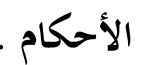

وقد أبان الخاسبي عن طريقته التي انتهجها في هذا الأمر ، وهي أن تحديد الغاية سابق على مجرد النظر ، وأن نظره سيكون لغرض الكشف عن الحقائق ، وليس مجرد نظر عابر غير محدد المعالم . فأعلن عن غايته وعن الهدف الذي يريده من النظر ، وهو التماس الحق ، وطلب العلم والعمل ، وأنه قد نظر في المعارف المختلفة المتاحة أمامه في الجتمع الإسلامي نظرا دقيقا، فيقول: ( فلم أزل برهة من عمري أنظر اختلاف الأمة، وألتمس المنهاج الواضح والسبيل القاصد ، وأطلب من العلم والعمل ، وأستدل على طريق الآخرة بإرشاد العلماء ، وعقلت كثيرا من كلام الله عز وجل بتأويل الفقهاء ) (ب) فالإمام يعلن أن في الأمة اختلاف ، وأن ثمت طريق واضح عليه أن يلتمسه ، وهذا النظر ليس مجرد شكوك فيما عليه الناس، يستتبع نفي الحقائق، وإقامة الثبهات ، بل هو نظر دقيق يستتبع يقينا معرفيا إذا توافرت فيه الشروط الصحيحة . (ع)

انظر : الحارث الخحاسبي : فهم القرآن ص V\ץ ـ تحقيق : حسين القوتلي . دار الفكر . بيروت -

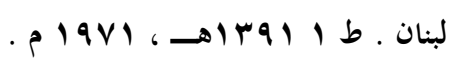

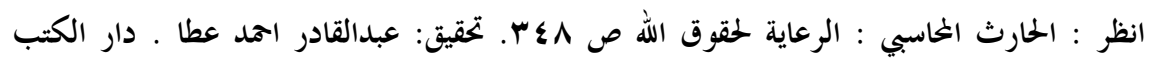

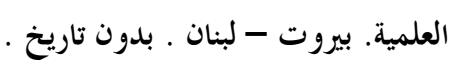

الحارث الخاسبي : النصائح ص • ج . ضمن مجموع كتاب الوصايا ـ تحقيق: عبدالقادر أحد عطا ـ دار

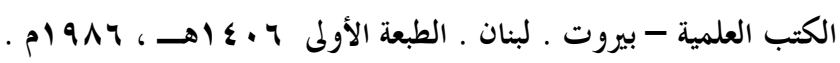

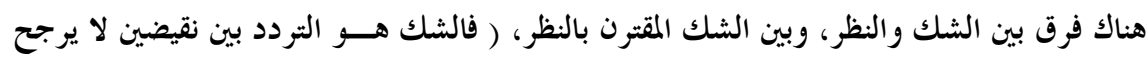




\section{منهــج الإمسام المحاسـبي في الوصسول لليقسين}

فإن الإمام الخحاسبي يدرك وجود الحق بين الأفكار المطروحة ، لكنه قد يكون خفيا لسبب ما ، في الفكرة أو في متبعيها ، وهذا يقتضي النظر فيهما جميعا . ويطلعنا الإمام الخحاسبي أن الشك قد بدأ يتطرق إليه لما انتهى إليه البيان بافتراق

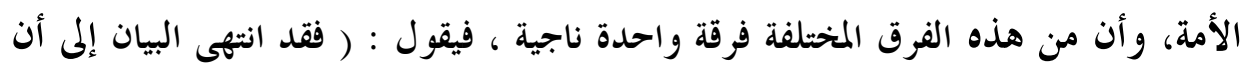

هذه الأمة تفترق على بضع وسبعون فرقة، منها فرقة ناجية والله أعلم بسائرها ) ( (1) ثم يعلن عن السبب الرئيسي لوجود مثل هذا الشك في عقله ونفسه ، وهو أنه

رأى ( كل صنف منهم يزعم أن النجاة لمن تبعهم ، وأن المهالك لمن خالفهم ) (Y) . فالخاسبي في هذا النص قد بدأ النظر في أمر الأمة بعد ما وصله أمر اختلافهم ، وأن نبينا ( صلى الله عليه وسلم ) لم يعين لنا الفرقة الناجية بالاسم بل عينها بالمنهج و السمات ، ولذلك لما بدأ الإمام الخاسبي في النظر وجد أن الكل يزعم أنه الناجي وحده ، وأنه الممثل الوحيد للفرقة الناجية التي أخبر عنها المصطفى ( صلى الله عليه وسلم ) .

= العقل أحدهما على الآخر ، وذلك لوجود آمارات متساوية في الحكمين ، أو لعدم وجود أية أمارة

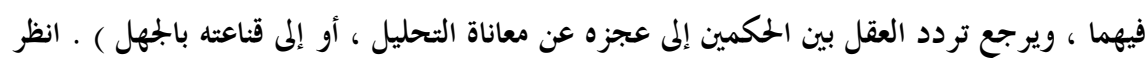

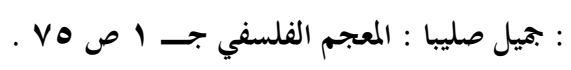

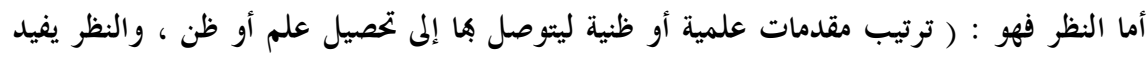

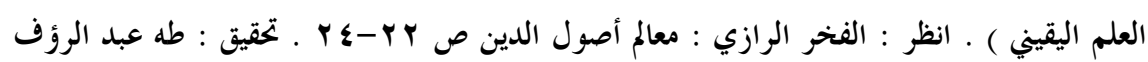

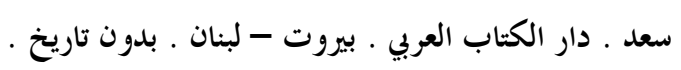

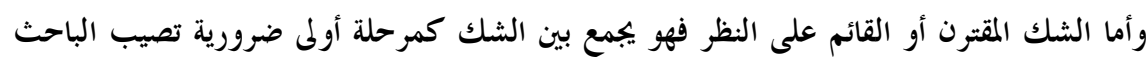

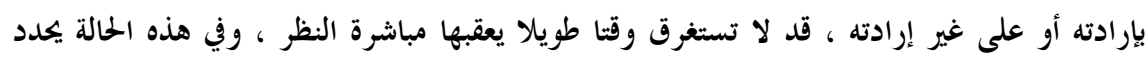

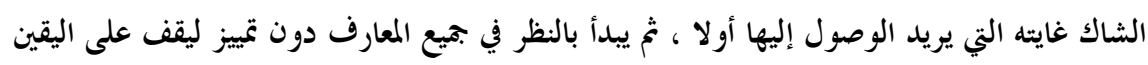

$$
\begin{aligned}
& \text { ، مثلما فعل الإمام الخاسبي . }
\end{aligned}
$$

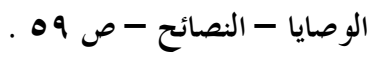

$$
\begin{aligned}
& \text { الوصايا - النصائح -ص . }
\end{aligned}
$$




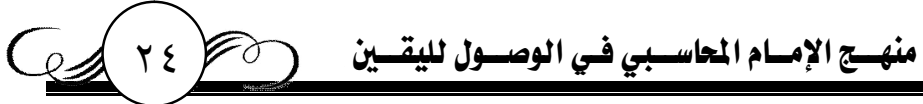

و كان هذا سببا قويا لأن يبدأ الإمام الخحاسبي بالنظر في هذه الأفكار المطروحة

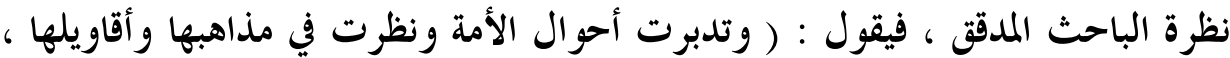
فعلقت من ذلك ما قدر لي ، ورأيت اختلافهم بحرا عميقا غرق فيه ناس كثير ، وسلم منه عصابة قليلة (1) ، ورأيت كل صنف منهم يزعم أن النجاة لمن تبعهم وأن المهالك

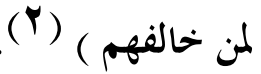

وبعد هذه النظرة الكلية للأفكار والأقوال ابتدأ الإمام بالنظر في الأشخاص مستخدما أسلوب التحليل الدقيق للأصناف الموجودة في الجنمع الإسلامي ، فوجدهم تسعة أصناف : ( منهم العالم بأمر الآخرة ، لقاؤه عسير ، ووجوده عزيز لماليز ، ومنهم الجاهل

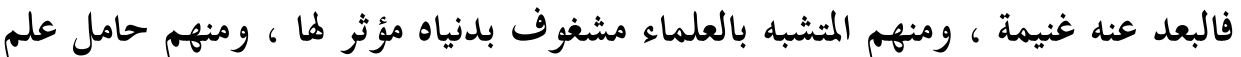
منسوب إلى الدين ملتمس بعلمه التعظيم والعلو ، ينال بالدين من عرض الدنيا ، ومنهم

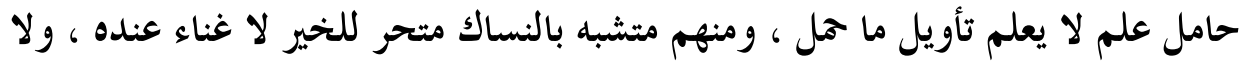
نفاذ لعلمه ، ولا متعمد على رأيه ، ومنهم منسوب إلى العقل والدهاء ، مفقود الورع المعاع و التقى ، ومنهم متو ادون على الهواء واقفون ، وللدنيا يذلون ورئاستها يطلبون ، ومنهم شياطين الإنس عن الآخرة يصدون، وعلى الدنيا ينكالبون ، وإلى بمعها يهرعون ، وفي الاستكثار منها يرغبون ، فهم في الدنيا أحياء ، وفي العرف موتى ) ("آ). وبما أن الإمام الخاسبي طامح في الوصول لليقين المعرفي ، فإنه وبكل تجرد بدأ

هذا النص يؤكد الفكرة التي تحدثت عنها سابقا عند الإمام الخحاسبي وهي أنه قد حدد وجهته قبل النظر ، وأنه كان يعرف الحق ، لكنه أراد أن يؤكده لنفسه ، ولمن يقرأ كلامه من بعده أو يسمعه ، وأراد

$$
\begin{aligned}
& \text { نقل تجربته كاملة ، وإن كانت ليست بتفصيل كبير . } \\
& \text { الوصايا - النصائح - ص • . . }
\end{aligned}
$$

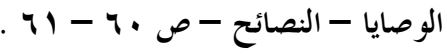


يفتش عن موضعه في هذه الأصناف ؛ حتى يتسنى له الحكم على نفسه أولا قبل أن يحكم على غيره ، أو ينصحه ، ولكي يرشد نفسه للمنهج الواجب اتباعه ، وقواعد هذا المنهج ، والسبب الذي أدى إلى وقوع أصناف من الناس في الضلال ، فيقول : ( فنفقدت في الأصناف نفسي وضقت بذلك ذرعا ، فقصدت إلى هدى المهتدين بطلب السداد و الهدى ، واسترشدت العلم ، وأعملت الفكر ، وأطلت النظر ، وتبين لي من كتاب الله وسنة نبيه وإجماع الأمة ، أن اتباع الهوى يعمي عن الرشد ، ويضل عن الحق ، ويطيل المكث في العمى ) (1) (1) والإمام الخاسبي بنظرته هذه قد وضع يده على الداء المتوطن في نفوس الفرق الضالة ، وهو اتباع الهوى ، وأن ذلك الاكتشاف لم يكن من نفسه ، بل كان من صحيح نظره في كتاب الله تعالى وسنة نبيه ( صلى الله عليه وسلم ) ، وإجماع الأمة . وهذا يدل على أن الشك الذي ساور الحارث الخاسبي لم يكن شكا مطلقا ، بل كان شكا مقترنا بالنظر الجرد هدفه الوقوف على الحقائق ، والتثبت من صدقها ابتغاء حصول اليقين ، فالإمام الخاسبي : أولا : حدد الهدف من البحث والنظر، وهو طلب الوصول للحق ، واليقين فيه. ثانيا : اعترف بو جود الاختلاف . ثالثا : وقف أوليا على الأسباب التي أدت المى الاختلاف . رابعا : نظر في الأفكار المختلف حولها جميعا دون استبعاد لأحدها على حساب الآخر . خامسا : نظر في المتبعين لهذه الأفكار ، وقام بتقسيمهم حتى يتسنى له صحيح النظر في كل صنف . 1أ.

سادسا : قاس نفسه على الأفكار المطروحة ، وتفقد نفسه في الأصناف التي قسمها .

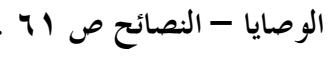




\section{منهـجه الإمسام المحاسـبي في الوصسيول لليقسين}

سابعا : استصحب أثناء نظره الجمع على صحته عند الجميع ، وهو كتاب الله تعالى ،

$$
\text { وصحيح سنة نبيه ( صلى الله عليه وسلم ) ، وإجماع الأمة (1) . (1) . }
$$

ثامنا : اعترف بوجود معوقات أساسية تثثل حائلا بين الحق وطلبه ، وأهمها خطرا

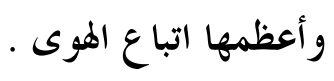

والإمام الخاسبي حتى اللحظة لم ينظر في الأفكار نظرة الناقد ، بل نظر إليها نظرة

معرفية وصفية جامعة مخافة أن يكون نظره غير صحيح ، أو أن يكون ذلك من كيد عدوه - الشيطان والنفس -، فيقول : ( وإنما اشتغلت بالوصف اضطرارا ، حيث رأيت نفسي خارجا منها جميعا (؟) ، فاعننيت بععرفة وصفها و الهداية إليها ، رجاء ان يوصلني

إلى نفس المنفعة و المداية إليها ، و الله المستعان على ما نقول ونضمر ) (إلى وحين أراد النظر الصحيح فإنه يعلن أنه قد أسقط الهوى عن نفسه ، وتلك هي المرحلة الثانية من مراحل صحيح النظر حتى يصبح نظرا بجردا وليس مجرد شك وووصف . إسقاط الهوى

الهــوى : هو محبة الإنسان الشيء وغلبته على قلبه (ع) ) . وعند الخحاسبي يعني : ( تعلق النفس بالثهوات ، وميلها إلى الراحات ، فعلى قدر الثهوات يتمكن منها الضعفي لرئ

$$
\text { ، فيستولي عليها الهوى ) (•) }
$$

المقصود بإبماع الأمة هنا ما أجمعوا عليه دون اختلاف فيما بينهم ، والمقصود هنا ما اتفقت عليه الفرق

$$
\begin{aligned}
& \text { جميعا ، وهو عدم اتباع الهوى . } \\
& \text { أي المعارف المتاحة في عصره . } \\
& \text { انظر : الخاسبي : آداب النفوس ص ^^ . } \\
& \text { لسان العرب جـ } 10 \text { ص اVV . } \\
& \text { الوصايا - القصد والرجوع إلى الله تعلى - ص • بr . . }
\end{aligned}
$$




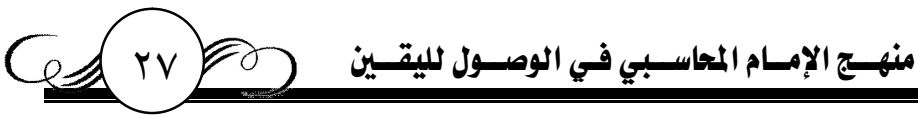

والسبب في الدعـــة إلى إســقاط الهوى والثــهوة ( أفما ضد النظر والعلم

والبيان ) (1)

ولأجل ذلك فإن الخاسبي يؤكد على ضرورة إسقاط الهوى وعدم اتباعه حين طلب اليقين ، وقد طبق ذلك على نفسه بعد خروجه من مرحلة الشك والنظر الوصفي

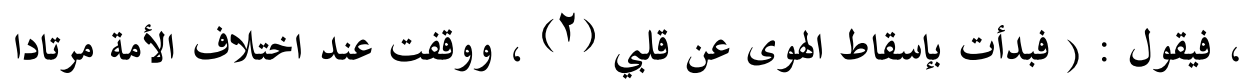

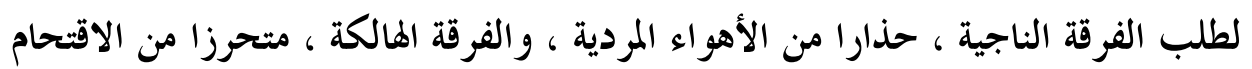

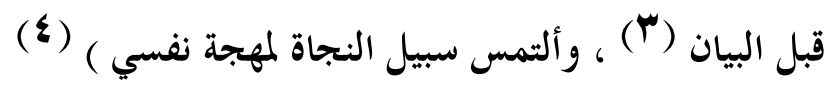
ويمكن أن نستخلص من النصوص السابقة مع نصوص أخرى الآليات التي استخدمها الخاسبي في منهجه للوصول إلى اليقين في مرحلته الأولى :

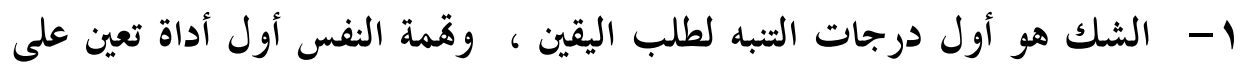

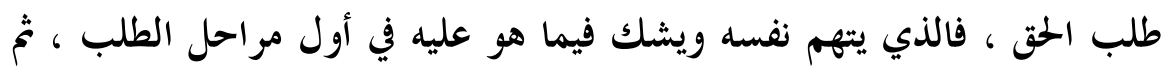

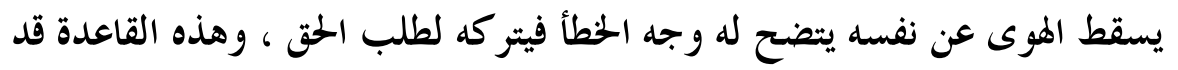

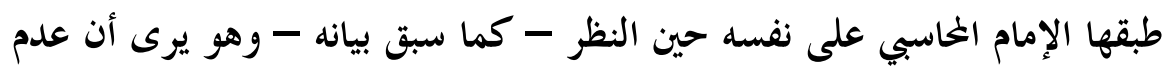

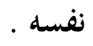

وقد خصص الخاسبي القلب بذلك ؛ لأن الهوى والشهوة والنية هي من الواردات على القلب ، ولا

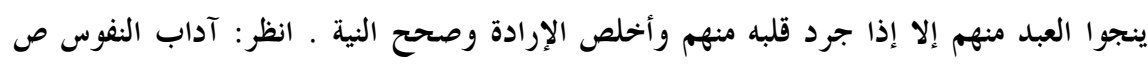
ذكر ديكارت في كتابه مقال عن المنهج نصا يحمل نفس الألفاظ والمعاني تقريبا عند حديثه عن القو اعد الواجب اتباعها عند البحث عن الحقيقة ، فيقول: ( ألا أقبل شيئا ما على أنه حق ما لم أعرف يقينا أنه

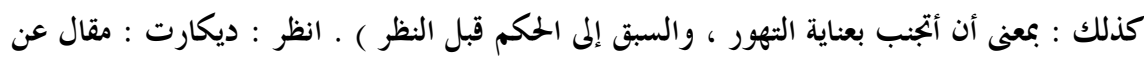

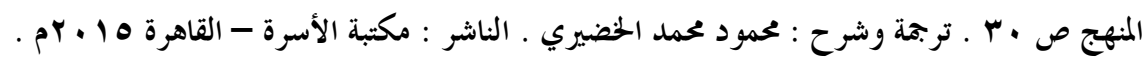

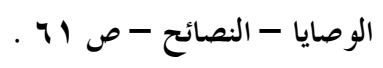




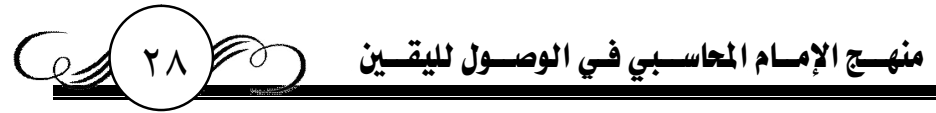

العمل هما سبيل لعدم الوصول للحقيقة ، فالفرق الزائغة إنما ضلت لاتباعها الهوى ، وإعجاها برأيها ؛ ولأفا لم تشك يوما فيما هي عليه لتعيد النظر ، وتصححه بآلاته التي تعين على الوصول لليقين ، فردا على سؤال حول كيفية اقام النفس ، وما

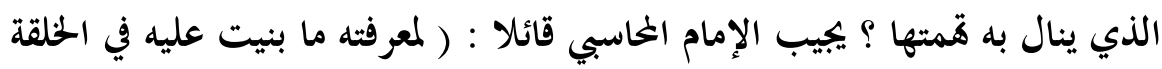

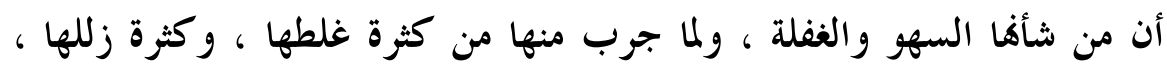
وسوء تأويله ما لا يحصى مرارا كثيرة ، وفي كل ذلك يرى أنه مصيب لا يشك

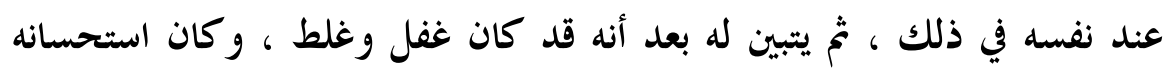

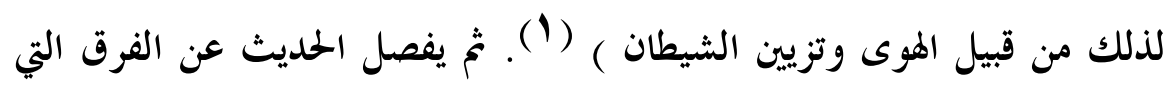

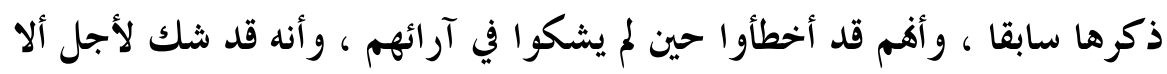

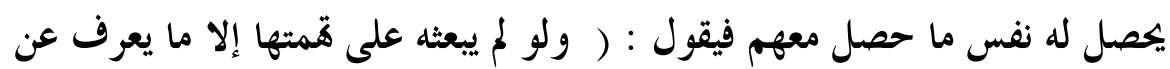

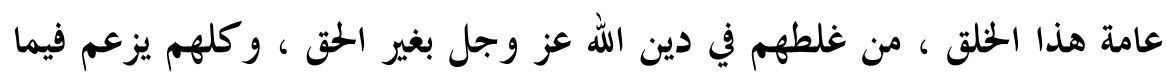

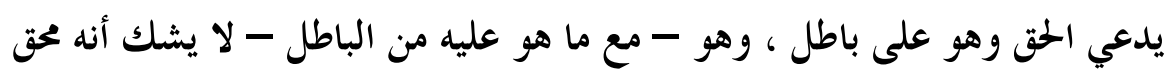

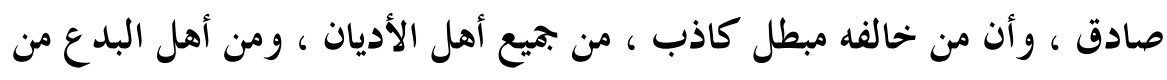

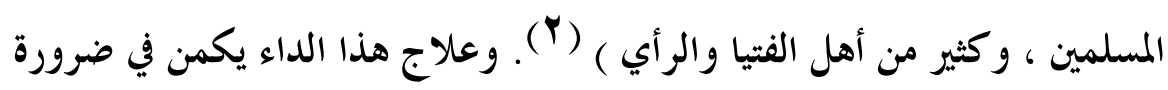

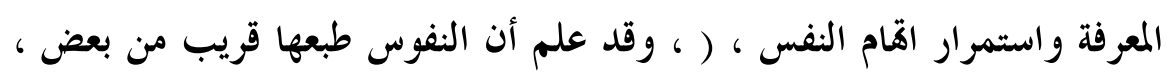

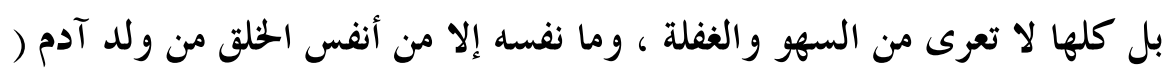

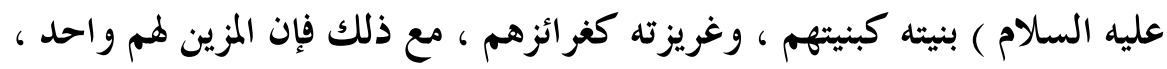

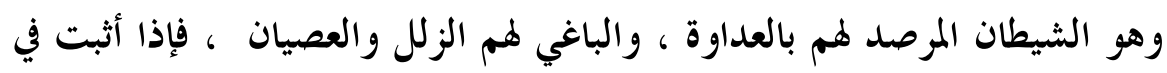

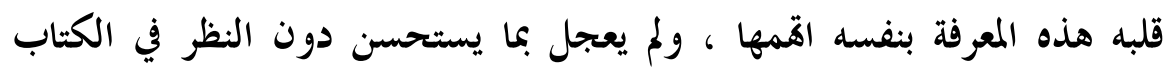

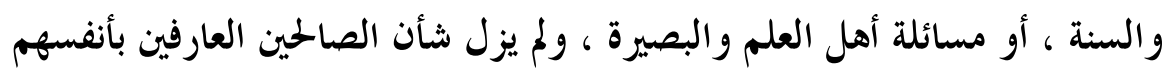




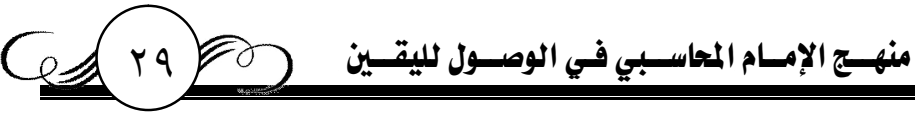

، ولم يزالوا متهمين لآرائهم خحائفين من أنفسهم ) (1) .و الإمام الخاسبي بهذا النص يرشد الإنسان إلى ضرورة اتحام النفس بعد معرفته بخطأ غيره ، فإذا كان

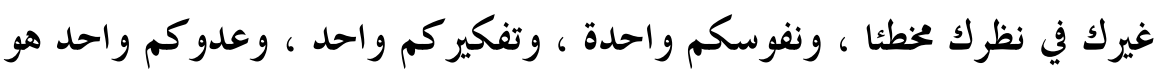
الشيطان ، فيجب عليك أنت أيضا أن تتهم نفسك كما اتمت غيرك ليظهر لك الحتق جليا فتتبت من الحق الذي أنت عليه ، أو تعرف مكامن الخطأ فتستخرجها بالنظر الصحيح لتصل بعدها إلى الحقائق الثابتة التي لا تقبل الشك .

r- حصر مواضع الشك والنظر : هذه قاعدة جليلة في منهج الخاسبي في الوصول لليقين ؛ إذ إنه يرمي إلى ضرورة معرفة الأمور التي هي محل الشك والنظر عند

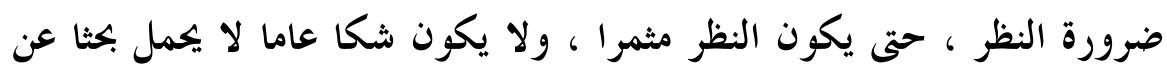

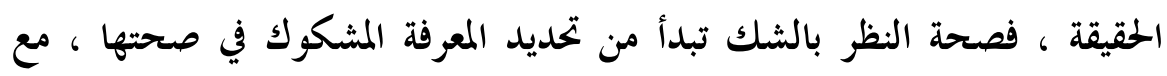
استصحاب المعرفة بوجود مسلمات لا تخضع للشك ، وأن الشك فيها يجعل البحث عن الحقيقة درب من الوهم والخيال ، يقول الخاسبي : ( فليعلم العبد المريد للصواب لدين الله ( عز وجل ) أن من الكتاب والسنة محكما بيّّ التلاوة مفسرا بإجماع ، وأن ذلك واضح لا يحتاج فيه إلى النظر والبحث ، ولا يجب على النفس

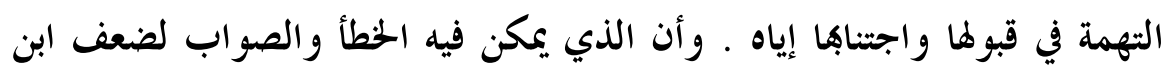
آدم وسهوه ، وغفلته وغلبة هواه له ، وتزيين عدوه له : ما اختلف فيه ، أو حادثة

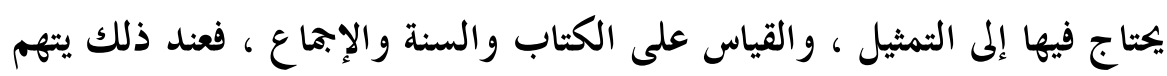
نفسه ، ويتثبت ولا يعجل ، إذ كان الخطأ في ذلك منه ممكنا ، فالعجلة وترك التثبت غرور وخطأ ، ولا يعتقد ما يستحسنه قلبه وزين في عقله إلا من كتاب 
منهـج الإمسام المحاسبـي في الوصسول لليقسين

$$
\text { وسنة ، او ما اجتمعت عليه الأمة ) (1). }
$$

ب- ضرورة إسقاط الهوى عن القلب ـ وفيه استبعد الإمام الخاسبي كل عمل قلبي من محبة وبغض قد يعيقه عن الوصول للحقيقة ، سواء كانت لشخص أو لفرقة . وذلك لأن ( الحب والبغض إذا أفرطا أنقصا الاعتدال ، وأفسدا العقل ، وصورا

$$
\begin{aligned}
& \text { الباطل في صورة الحق ) (؟). } \\
& \text { ع - الوقوف عند الاختلاف مع طلب الحق . }
\end{aligned}
$$

هـ - الحذر من معوقات الوصول للحقيقة ، وهي الأهواء المردية ـ فللهوى مداخل كثيرة بين الحتق وطلبه ، وبين اليقين والوصول إليه ، لابد من التخلص منها بميعا حال

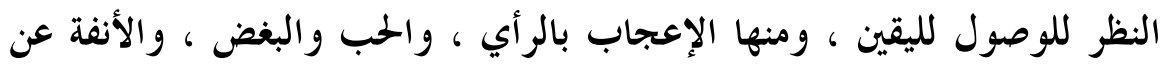
قبول الحق ، يقول الخحاسبي : ( إن الحق في كل أمر بين ، والباطل في كل حال داحض ، إلا أن كثيرا من الناس لا يعرف وجه مطلبه ، وبعضهم يعرف بعضه لئه

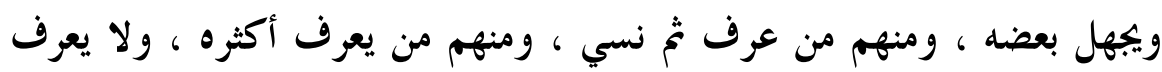
أسهل طرقه ، وأقرب وجهه ) (بّ) . ثم يقول : ( و الذي يمنع من الفهم الأنفةُ التي تمنع من الخضوع للحق ، وحب الغلبة الذي يبعث على الجمل ، والجزع من التخطئة التي تمنع من الإذعان بالإقرار بالصواب ) (ع) ـ فكل تلك معوقات

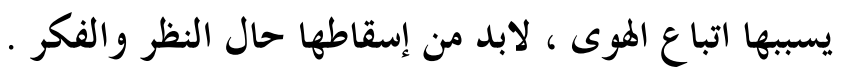

$$
\begin{aligned}
& \text { الرعاية ص VOV . . . } \\
& \text { العقل ص بrr. } \\
& \text { انظر : العقل ص سبr . } \\
& \text { نفسه ص ع זr. }
\end{aligned}
$$




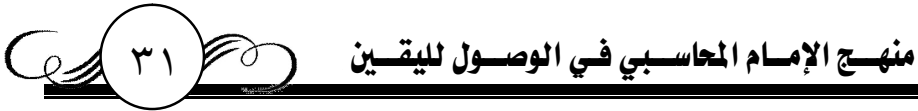

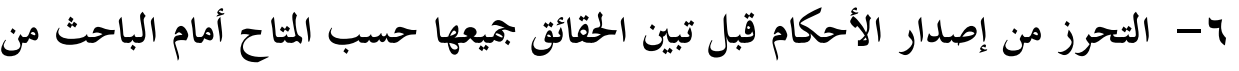

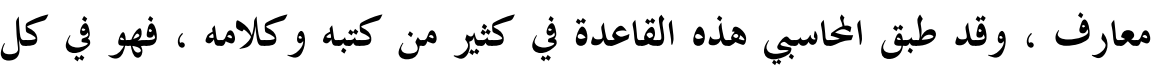

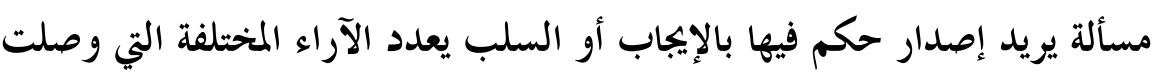

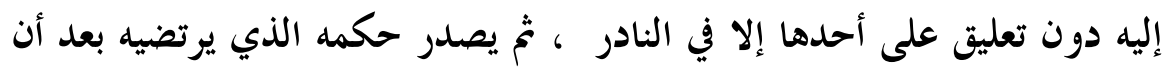

$$
\text { بين المعارف (1). }
$$

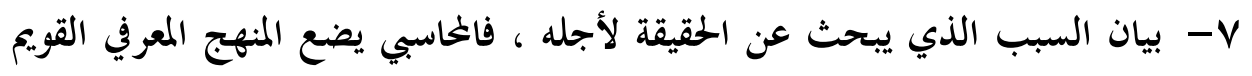
للبحث عن الحقيقة ، والوصول لليقين ، وهو تحديد المسارات المهمة للبحث ،

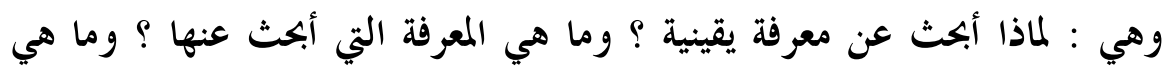

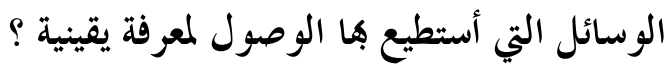

وقد أجاب الخاسبي بدقة عن هذه الأسئلة المطروحة فهو يبحث عن المعرفة لأجل النجاة في الدنيا والآخرة ، و المعرفة التي يبحث عن اليقين فيها هي المعرفة الدينية القائمة

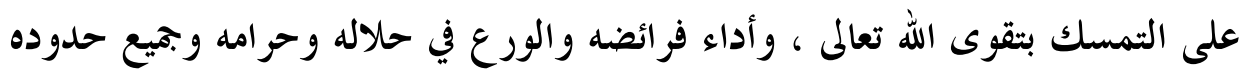

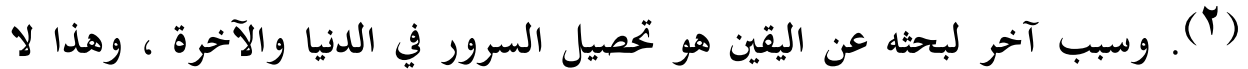

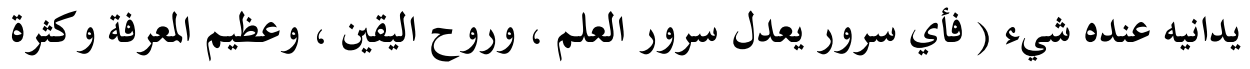

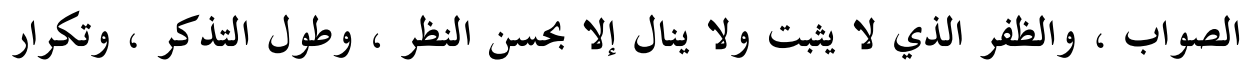

(r) الفكر ) وأما الوسائل التي تحقق ذلك ، فقد حددها الخاسبي بخمسة أشياء :

انظر على سبيل المثال : تقسيمه للعقلاء عامة ، واختياره للعاقلين عن الله تعالى كوفم أهل العقل . في

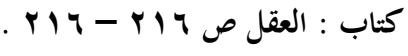

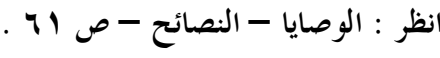

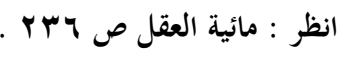




\section{منهـج الإمسام المحاسـبي في الوصسول لليقسين}

أولا : النية الصادقة : يراها الخاسبي مرافقة لكل عمل صالح ، ولكل معرفة :

فلا تكون النية إلا بالمعرفة ، ولا تكون المعرفة إلا بنية ، ولا تستغني إحداهما عن الأخرى ، فجد واجتهد في صلاح نيتك ، فإِن بها تدرك الخلاص والإخلاص ) ( (1) ، وليست النية الصادقة وحدها هي التي ترافت العمل والمعرفة ، فحيثما كانت صحبها الهوى و الثهوة ، و كلهم يردون على القلب ، والخاسبي ينصح بتخليص النية من بميع الآفات ، فيقول : ( فاقصد إلى نيتك ونقها من جميع الآفات ، من الله علينا وعليك بمعرفة النية ، وصلاحها من بميع العيوب ) (Y)". ويقول : ( فعليك بصلاح نيتك ، فإِن بها صلاح آخرتك ودنياك جميعا ، فاقصد أول ما تقصد إلى نيتك ، فإنما العزم بالنية ، ولا يصل إليك شيء من معرفة الرب تبارك وتعالى إلا به ، فعليك بنيتك فإنه عمل خفي فيما بينك

وبين الله تعالى ، فلا تعمل شيئا إلا بنيتك ) (r).

والخحاسبي يؤ كد على أن الصدق في النية لا يأت بعد حسن القصد والإقبال إلا

بتوفيق الله تعالى (ع) ، فهو سبحانه وحده ( قادر على أن يسخر الهوى للصدق ، وإن كان فقليل ، والذي يعرف هذا القليل في الناس هم قليل ، والذي يجهله كثير ؛ لأن

الإمام الخاسبي : شرح المعرفة وبذل النصيحة ص هـ ـ تحقيق : مجدي فتحي السيد ـ دار الصحابة

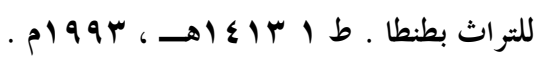

$$
\text { نفسه . نفسه ص ع ه . }
$$

الحقيقة أنه ليست النية وحدها عند الخاسبي التي تأتي بتوفيق الله تعالى ، بل كل عمل يعمله الإنسان ،

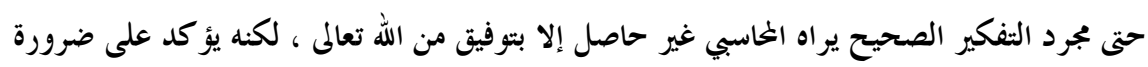

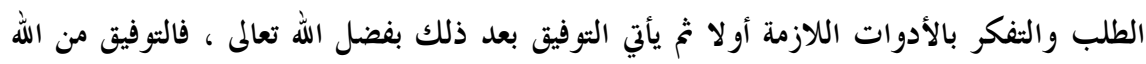

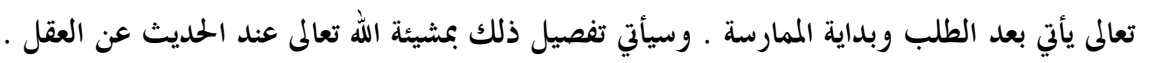

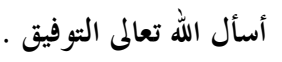




\section{منهـج الإمسام المحاسـبي في الوصسول لليقسين}

الإرادة للعمل قبل العمل ، والهوى والشهوة مما يلي العمل ، والنية والصدق من ورائهما

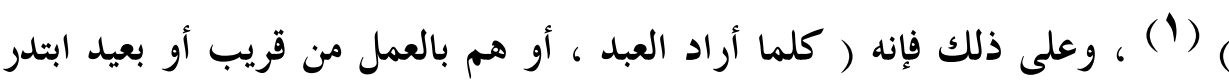
الهوى والشهوة ، والنية الصادقة فيهما إلى القلب بذكر ما يرجى وما يؤمل من مثل

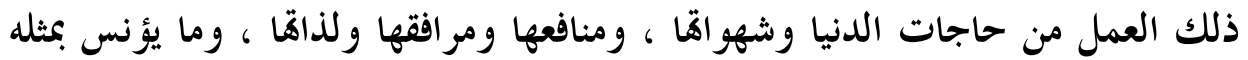
من الأشياء ، وما حسن موقعه من الناس ، وذكرهم له بالثناء والخمدة والقدر والجاه

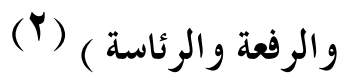

ثانيا : الإرادة الصادقة : هي تلك التي تجعل العبد يميز بين الهوى والثهوة ، وبين

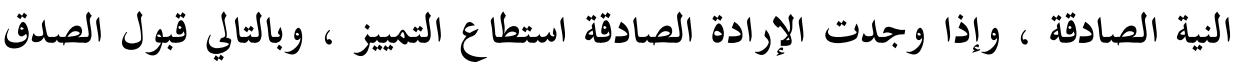

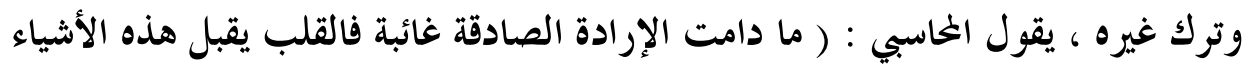

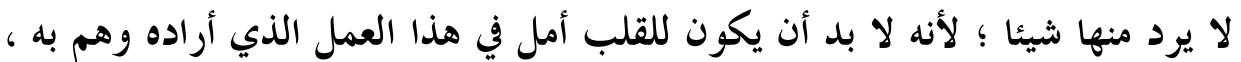

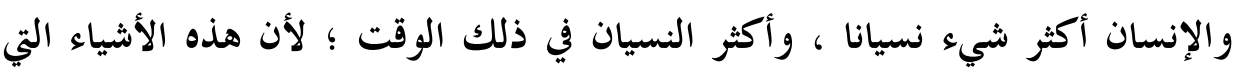
جاءت هما النفس والهوى إلى القلب مما ذكرنا من الثناء والخمدة والرفق والقدر والجاه والرئاسة والمززلة كلها مما يتحلى به القلب ويشتهيه ويرغب فيه ؛ فلذلك تكثر الغفلة

والنسيان للإرادة الصادقة ) (باد) وتتحقق المعرفة الحقيقية حين تكون الإرادة الصادقة أمام الهوى ، وشهوة النفس ، وذلك يتحقق بالتوفيق الإلهي للعبد بعد الطلب : (فمن شاء الله عز وجل أن ينعم عليه

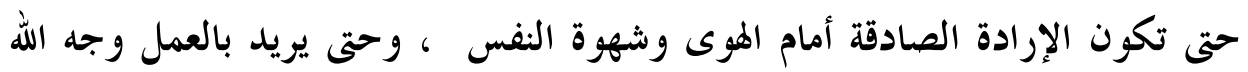

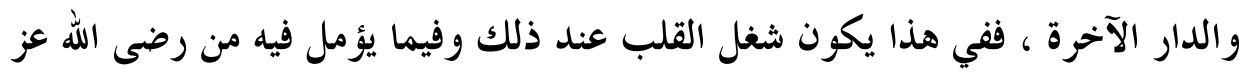




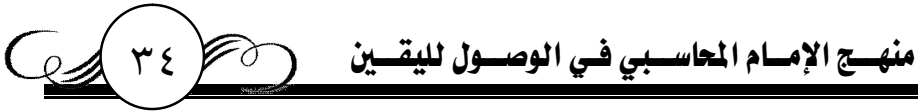

وجل وثوابه ، وما جاءت به النفس والهوى مما ذكرناه لم يقبله القلب ، ورده عليهم . ففي هذا اعظم النعم وعلى صاحبه أكثر الشكر ) (1) ، وإن كان العكس فعلى صاحب الإرادة الوقوف للنظر والفكر الكثير حتى ينقي قلبه ، يقول الخاسبي : (وإن كانت النفس والهوى والشهوة سابقات على الإرادة الصادقة ، فلا بد لصاحبها من الوقوف والنظر والفكر حتى ينقي قلبه مما عرضت به النفس والهوى والشهوة ، ويجعل إرادة الله مكان ذلك وأمامه فيقبله القلب ساءه أو سره ، ثم يتحفظ ويتعاهد حتى يختم العمل الذي افتتحه بالإرادة الصادقة بمثل ذلك ، وبعد فراغه من العمل ما دام الروح في

$$
\text { (Y) (Yسده ) }
$$

وهذا الأمر يعتبره الخحاسبي من أصعب درجات الوصول في المعرفة ، وتصحيح العمل لله تعالى ، بل هو عنده أشد من نقل الصخر ، فيقول : (واعلم أن إحكام هذا أعز وأشد من نقل الصخر ، وركوب الأسنة إلا من رزقه الله إحكام ذلك ، و العناية به مخافة تلف نفسه ، وإحباط عمله ؛ لأن العدو ملح مجد محتال له في ادخال الآفات التي تفسد الأعمال ، فهو يرصده قبل دخوله في العمل وبعدما يدخل فيه وبعد ما يخرج منه ) (ب) . ورغم ذلك كله فإنه ربما يعرض العدو للإنسان بعد تقديم الإرادة الصادقة والنية الصادقة ، ونفي الهوى ، ومخالفة الثهوة ، (فإن صده بعد دخوله في العمل فعرض له بما ذكرنا من الآفات التي تفسد الأعمال ، فإن قبلها حتى يختم العمل بقبولها فسد عليه أصله

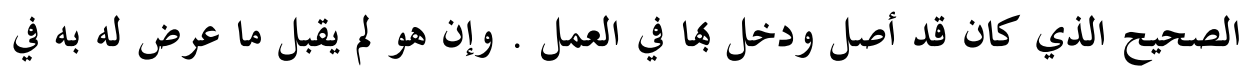
العمل ونفاه ودفعه لم يضره ذلك شيئا ـ وإن هو قبله ثم انتبه قبل أن يفرغ من العمل

$$
\text { نفسه ص س ب 1 -ع • 1 . }
$$




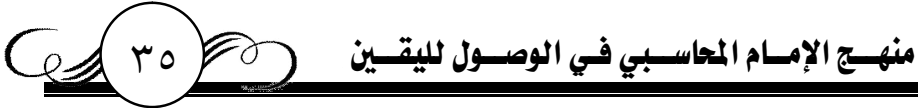

فندم ورجع وتيقظ وأزال الغفلة ثخ ختم العمل بالندم لم يضره ذلك شيئا ) ( '). ثالثا : مراقبة الله تعالم عند كل عمل : المراقبة عند الخحاسبي من الأمور الجليلة في طريق تحقيق اليقين ، وهي عنده درجتان : بداية ، والمر اقبة فيه : ( علم القلب بقرب الله

$$
\text { عز وجل ) (Yَ) ، وهذا هو أول المر اقبة ، ولا يسمى العبد فيه مراقبا . }
$$

وإنما يسمى مراقبا في الدرجة الأخرى من المراقبة ، وتعني عند الخحاسبي : ( دوام

علم القلب بعلم الله عز وجل ، في سكونك وحر كتك علما لازما للقلب بصفاء اليقين ، وكشف غطاء حجب الظلم ، غير قاطع عن النظر بمشاهدة الغيب ، فعندها تغيب أسباب الغفلة عن القلوب بدواهيها ، فيعقل عن الله تعالم نصائح الحكمة بما فيها ، ويكثف له اليقين عما فات منها ) (بّ)" ويصل العبد لهذه الحالة ( بقطع علائق الأشفال

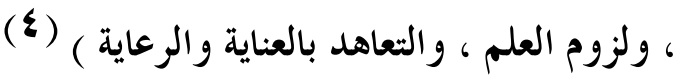
ويرجع الخاسبي أهمية المراقبة في هذا الباب لسبب كثرة الحداع و الغلط ، و والحطأ و العمد ، والنسيان والفتن والبلايا ، وغيرها كثير ، فإِان الآفات ( أكثر من أن يضبطها

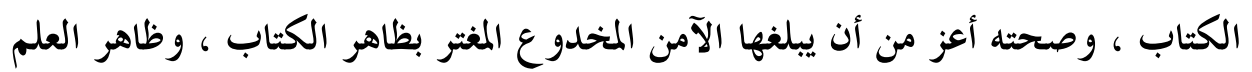
، و إنما يدرك ذلك كله ويعرفه أهل العناية بأنفسهم الذين خافوا على أعمالهم أن تبطل ، وخافوا على أنفسهم أن تتلف ، ولا ينبغي لعاقل أن يفتر عن مفاتشة همثه ، ومحاسبة نفسه ، ونقاء ضميره ومراقبة الله سبحانه وتعالى عند كل عمل يريد أن يعمله وإلا فهر

$$
\begin{aligned}
& \text { آداب النفوس ص ع • 1 -0 1. } \\
& \text { الوصايا - القصد والرجوع إلى الله ص باץ . } \\
& \text { (ب) }
\end{aligned}
$$

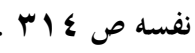




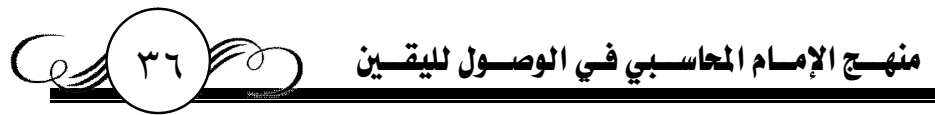

مخدوع ، والله نسأل التوفيق والفهم والعزم الصحيح والإرادة الصادقة ) (1)

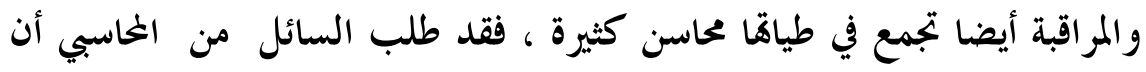
يدله على حالة تثبته في التواضع ، وتجمع له الرعاية ، وتتزج السرور بالمقدور ، وتسقط

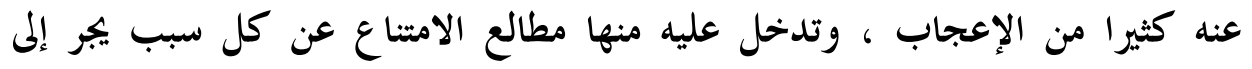

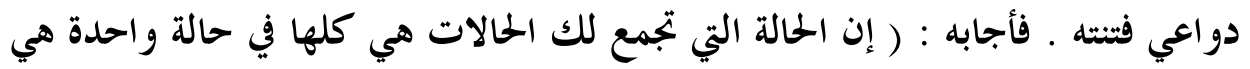

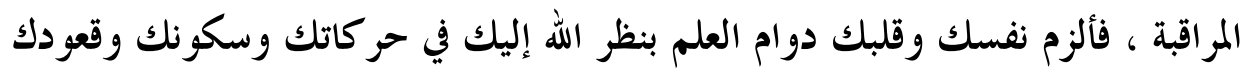

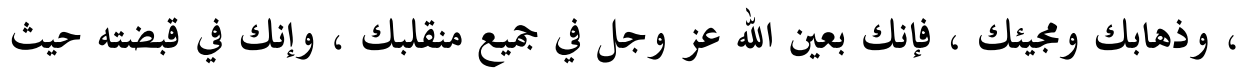

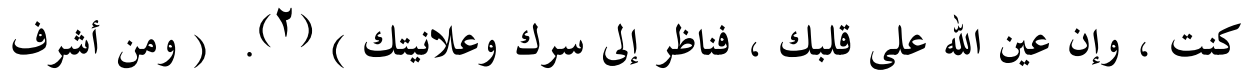

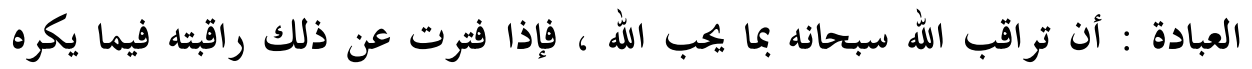

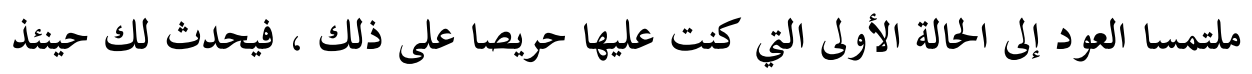

إليها حنين شديد ، فإنه إذا رآك كذلك تحن وتحرص رد عليك ما سلبك ) ("َّ).

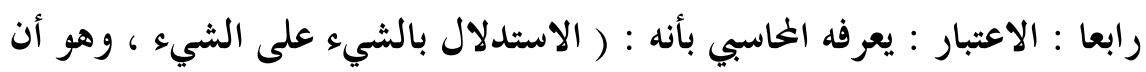

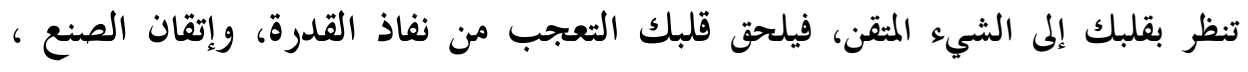

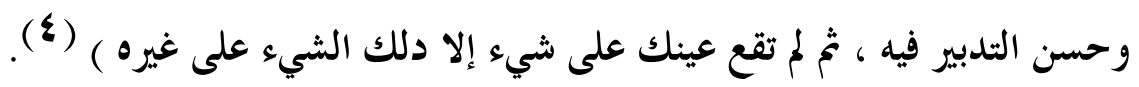

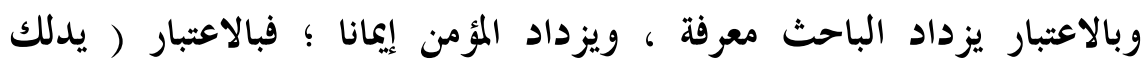

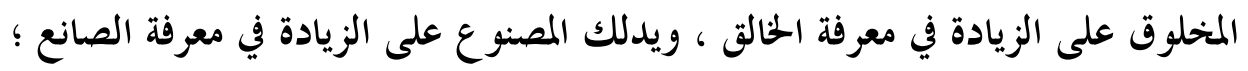

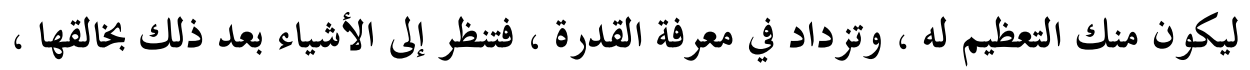

$$
\begin{aligned}
& \text { آداب النفوس ص } 9 \text { ـ } 1 \text {. }
\end{aligned}
$$

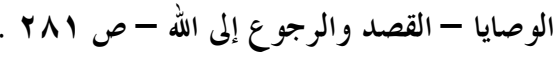

$$
\begin{aligned}
& \text { آداب النفوس ص rr| }
\end{aligned}
$$

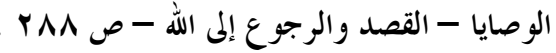




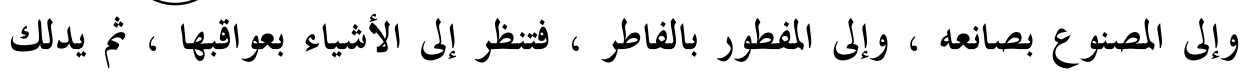

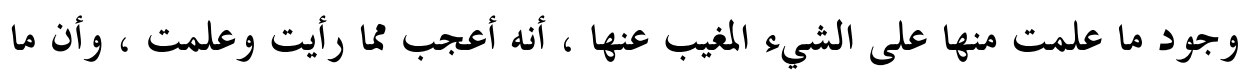

$$
\text { علمت عند ما لم تعلم كلا شيء في لا شيء ) (1). }
$$

والناس مثفاوتون في الاعتبار ( على قدر صحة العقول ، وقوة الإيمان ) (ץ).

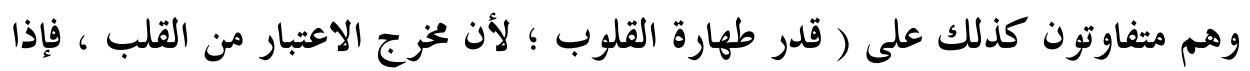

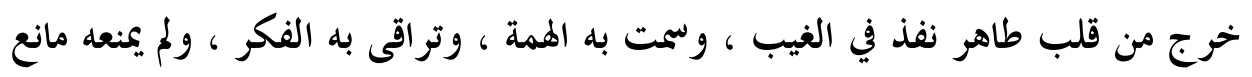

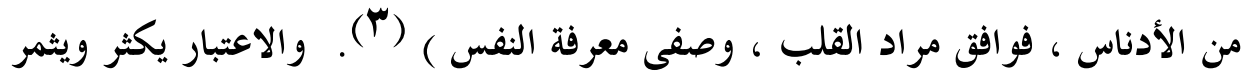

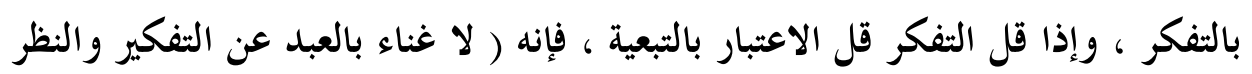

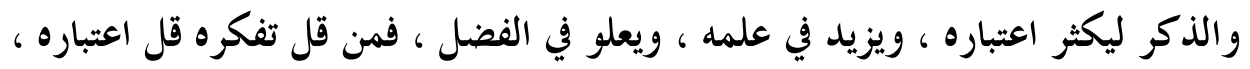

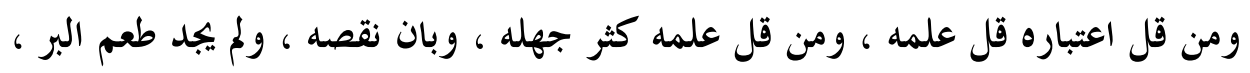
ولا برد اليقين ، ولا روح الحكمة ) (؟). فصحة الاعتبار وسيلة من وسائل تحقيق المعرفة

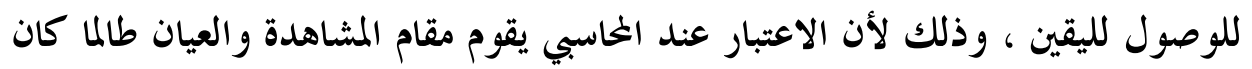

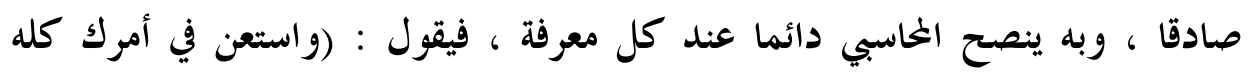
بالاعتبار ؛ فإن الأمر لا يزال مستورا منك ، أو غائبا عنك فِإذا نظرت إليه نظر المعاد المعتبر

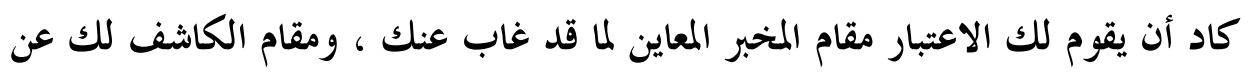

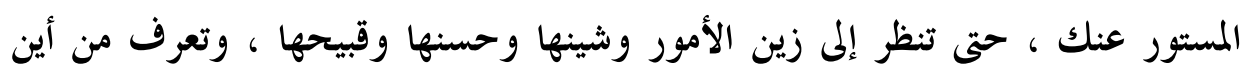

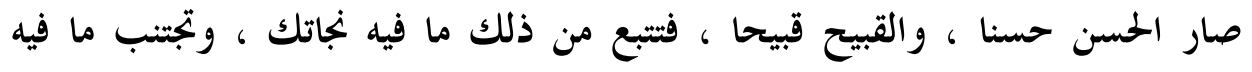

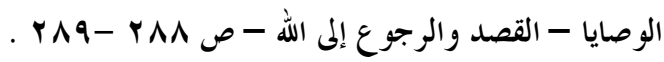

$$
\begin{aligned}
& \text { (ץ) ن (ץسه . } \\
& \text { ( ) ( }
\end{aligned}
$$

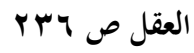


هلكتك وتعرف الناس بالاعتبار على منازلمم في لحن القول ، ولحن الفعل ، وتعرفهم

وتعرف منازلهم ومذاهبهم بنور الاعتبار ومواهب الإلهام إن شاء الله تعالم ) ( (1)

خامسا : الاستكثار من المعرفة : يرى المحاسبي أن ليس للمعرفة حد تنتهي إليه ، بمعنى أن يعتقد الباحث أنه قد اكتفي معتقدا أنه وصل لمراده ، فيجب الاستكثار من المعرفة كوسيلة من الوسائل التي تحقق اليقين المعرفي ، يقول الخاسبي : (قاستكثر من المعرفة ما قدرت فليست المعرفة كالعمل ، للعمل حد ينتهي إ ليه ، وليس للمعرفة حد

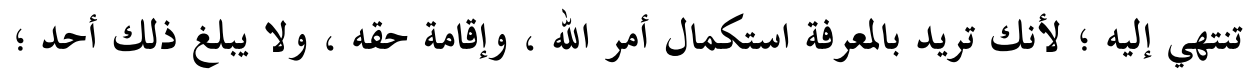
لأنه سبحانه وتعالم أجل وأعظم من أن يبلغ الآدميون كنه حقه ، غير أفم يتباينون فيه

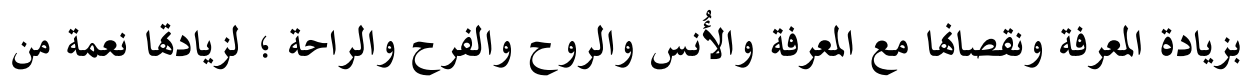
الله ونقصاها عقوبة من الله بذنب أو تضييع شكر ) (Y) . - الإقرار بصعوبة الكثف عن الحقيقة وخوف فواتا .

q- تحديد المعرفة المراد بكثها ، ثم الانكماش في طلبها ، أو طلب من يدل عليها ، يقول

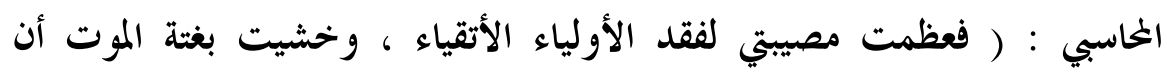
يفجأني على اضطراب من عمري لاختلاف الأمة ، فانكمشت في طلب عالم لم أجد الاء

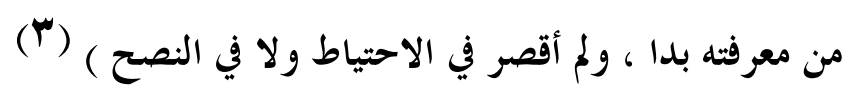

• 1- الاستقراء التام لجميع أفراد الموضوع المراد بحثه ، ثم استبعاد المعارف غير المرغوب

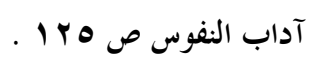

آداب النفوس ص צج 1 ـ ـ ونلمح من خلال هذا النص أن الخاسبي دائما ما يربط بين المعرفة وحسن

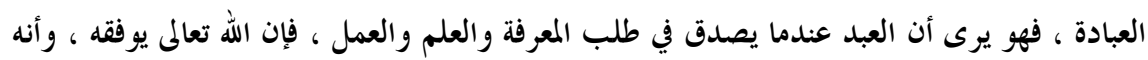

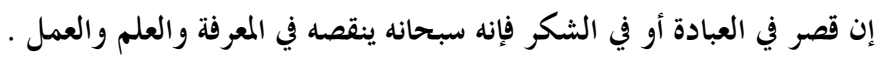

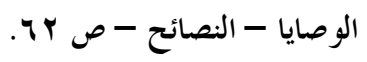




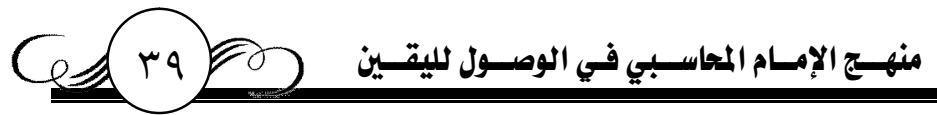

\section{فيها . (1)}

فالمعرفة التي يبحث عنها الخحاسبي هي تلك المعرفة اليقينية التي لا يتطرق إليها شك

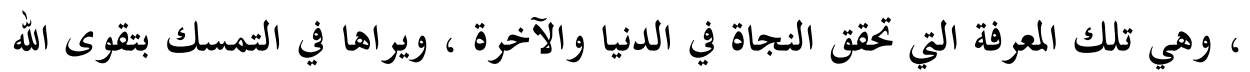

$$
\text { تعالى ، وأداء فر ائضه ، و الورع (Y) }
$$

وفي نص جامع للمراحل التي مر بها في المعرفة ، والتي سبق الإشارة إليها ، محددا أن مراحل الوصول لليقين ومن بعده النجاة تتحقق بفضل الله تعالم يقول الخاسبي :

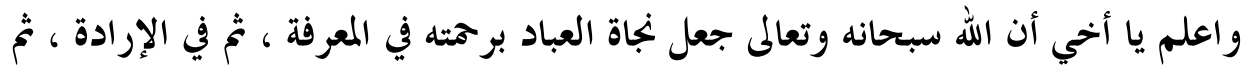
في ترك ما أمرهم بتر كه ، ثتم في العمل بعما أمرهم به ، ثتم في شكر نعمه التي أنعم بها عليهم قديما وحديثا ، ظاهرا وباطنا ) (بّ) . وهذا الترتيب عند الخاسبي مقصود ، فإن العلم يأتي

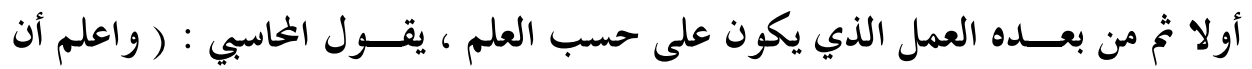
أنجى طـــريق للعبـــد : العمل بالعلم ، و التحرز بالحخوف ، والغنى بالله عز وجل ) (ع ( ).

سيأتي مزيد بيان لهذه المسألة كواحدة من مراحل المنهج الذي اتبعه الخحاسبي للوصول لليقين في المعرفة

$$
\begin{aligned}
& \text { انظر : الوصايا - النصائح -ص ل7 اله . } \\
& \text { آداب النفوس ص • با . } \\
& \text { رسالة المسترشدين ص • با ـ }
\end{aligned}
$$




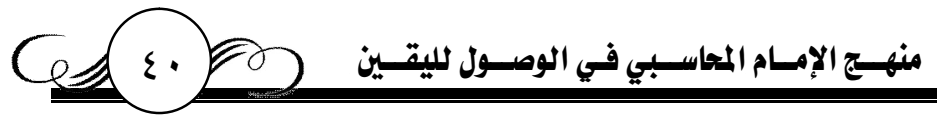

\section{المرحلة الثانية : تجريد آلة المعرفة}

عقب تحديد المعارف المرغوب فيها ، والدعوة إلى إسقاط الهوى ، لابد من تحديد آلة تبحث عن الحقيقة بوسائلها الصحيحة ، مجردة عن كل العلائق المعوقة عن الوصول للحقيقة لتضمن صحة البحث في المعارف ، ومن ثم الوصول لليقين فيها . والخحببي يرى أن هذه الآلة هي العقل الممتزج بالدليل الشرعي ، الموفق من الله

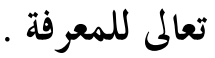

فالمعرفة في أساسها تصدر عن العقل (1) ، وهو زينة البشرية ، ومصدر للمعرفة

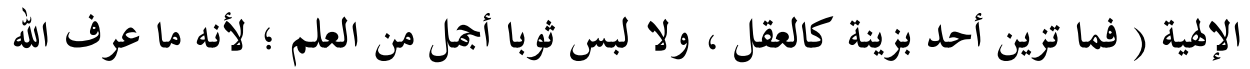

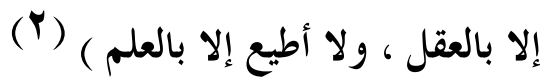

و العقل هو الذي تقوم به الحجة على العباد ، وهو مناط النكليف ( فإنما خحاطب

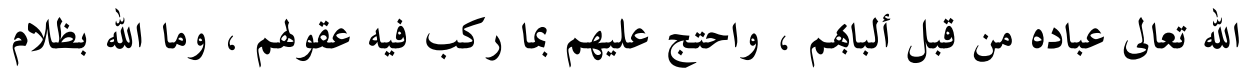

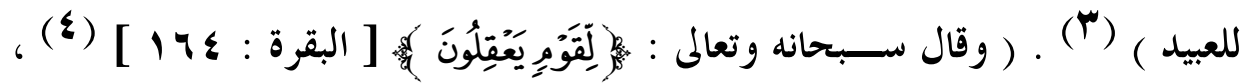

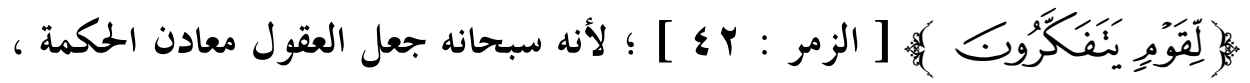

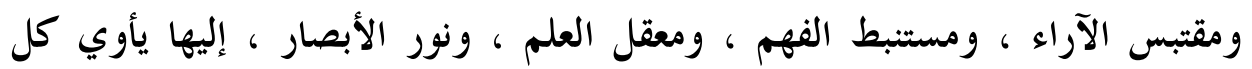

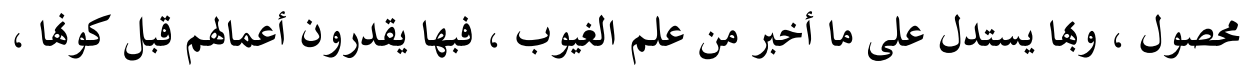

$$
\begin{aligned}
& \text { مائية العقل ص ه. • . . } \\
& \text { رسالة المسترشدين ص ^9-99 }
\end{aligned}
$$

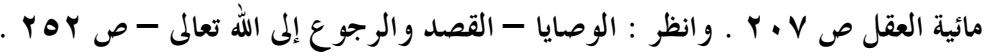

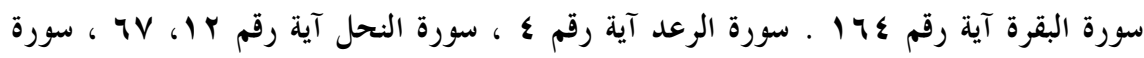

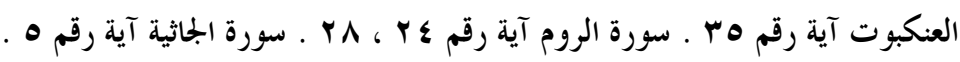




\section{منهـج الإمسام المحاسـبي في الوصسول لليقسين}

ويعرفون عو اقبها قبل وجودها ، وعنها تصدر الجوارح بالفعال بأمرها ) ( (1) . وتلك هي مهمة العقل الرئيسية التي نادى بها الخاسبي ، وهي ضرورة تحديد المعارف قبل الحوض في البحث ، وضرورة تحديد المراد من المعرفة قبل الولوج في البحث عنها ، وتقدير النتائج الفرضية للنتاج البحثي إيجابية كانت أو سلبية . تعريف العقل ، و كيفية تحقيق المعرفة .

تحقيقا للمبدأ الذي رسمه الخاسبي لنفسه في طلب المعرفة ، حين أكد على ضرورة التحرز من إصدار الأحكام قبل البيان الكامل ، وضرورة استقراء المعارف المتاحة قبل اختيار أحدها أو نفيه ، فإنه قد تكلم في سرد تعريفات العقل . وقد ذكر الآراء في تعريف العقل وما هيته ، مبينا أن من التعريفات المطروحة

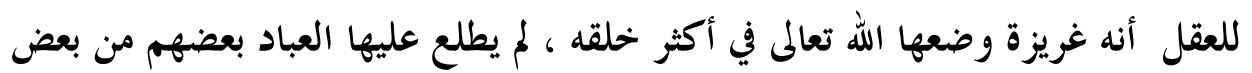
، ولا اطلعوا عليها من أنفسهم برؤية ، ولا ذوق ، ولا طعم ، وإنما عرفهم الله إياها

بالعقل منه . (广)

وعند المتكلمين فالعقل هو صفوة الروح أي خالص الروح (بَ) . وقال قوم : هو

نور وضعه الله طبعا وغريزة ، يبصر به ، ويعبر عنه (๕) . وزعم آخرون أن العقل معرفة نظمها الله تعالمى ووضعها في عباده يزيد ويتسع بالعلم المكتسب (•) . ـوقيل هو البصيرة

$$
\begin{aligned}
& \text { فهم القرآن ص צฯ ץ . }
\end{aligned}
$$

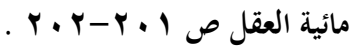

$$
\begin{aligned}
& \text { مائية العقل ص ع • ץ . } \\
& \text { نفسه . } \\
& \text { نفسه ص O. P. . }
\end{aligned}
$$


والمعرفة (1)

ثم اختار الخاسبي من هذه التعريفات التعريف الأول ، فيقول : ( والذي عندنا أنه

غريزة والمعرفة عنه تكون ) (Y) ، ( ومما يدل على أن العقل هو الغريزة التي بها عرف فأقر ، وعرف فأنكر ؛ لأن الإنكار فعل ، فكذلك ضد المعرفة فعل ، فمنه فعل عن طبع يوحيه الطبع كالضرة(ب) ، كمعرفة الرجل نفسه وأباه و وأمه ، و السماء والأرض ،

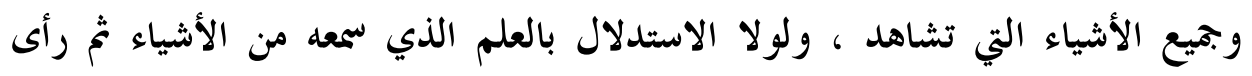
الأشياء لعرفها برؤيا ، ولم يعرفها باسم ولا تفصيل بين معانيها ، فلم يعرف عاقل أسماء

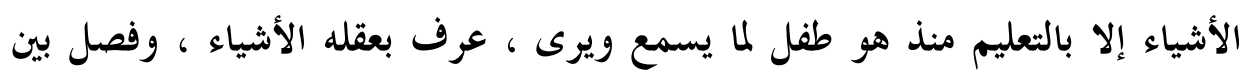
معانيها ) (ع) . . ( فالعقل غريزة جعلها الله تعالمى في الممتحنين من عباده ، أقام به الحجة على البالغين للحلم الحجة ، وأتاهم خاطب من قبل عقولهم ، ووعد وتوعد ، وأمر وفىى

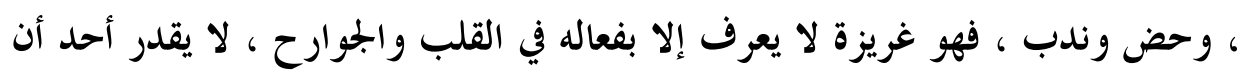

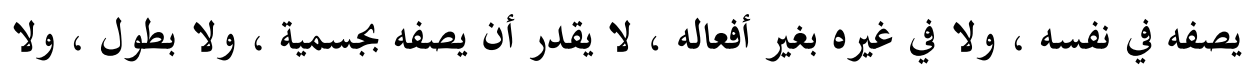
بعرض ، ولا طعم ولا شم ، ولا مجسة ، ولا لون ، ولا يعرف إلا بأفعاله ) (0) . فالغاسبي - من خلال هذا النص - يرى أن العقل غير موصوف ، وغير معروف في مكان محدد ، و أنه شيء غير القلب، وأن المتصف به لا يعرف إلا بأفعاله ، فإن كانت

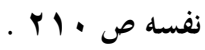

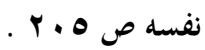

$$
\begin{aligned}
& \text { بمعنى : الضرورة ـ انظر هامش مائية العقل ص ه • ب . } \\
& \text { مائية العقل ص ه • Y-Y • • ب بتصرف يسير · }
\end{aligned}
$$

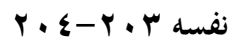




\section{منهـج الإمسام المحاسبي في الوصسول لليقسين}

أفعاله عاقلة بتمييزه بين النافع والضار ، عرف أن الله تعالى قد من عليه بالعقل ، وميزه

$$
\text { عن أهل الجنون والحمقى الذين قلت عقولهم (1) }
$$

فالناس تستدل على عقل العاقل ( إذا رأوا من أفعاله ما يدلهم أنه قد عرف ما

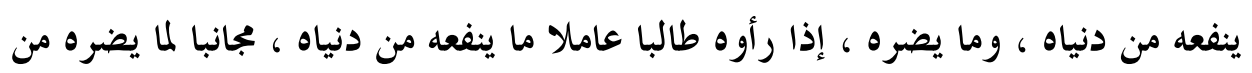
دنياه ، فسموا من كان كذلك عاقلا ، وشهدوا أن له عقلا ، وأنه لا مجنون ، ولا تايه ،

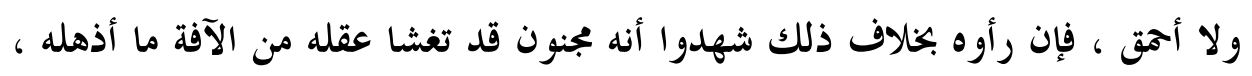

وأزال معرفته بمنافعه و مضاره ) (Y)

لكن الخاسبي لم يقف عند كون العقل غريزة فحسب ، بل عرفه بتعريف آخر

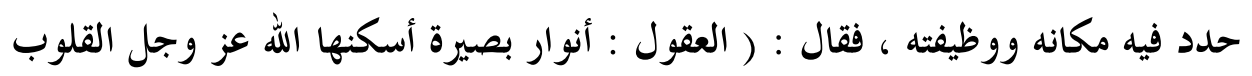
، يفرق بها العبد بين الحق والباطل ، في جميع ما يرد عليه من خطرات قلبه ، ونزغات عدوه ، ووساوس نفسه ، وما تعبد برعايته ) (بائ) والفرق بين التعريفين عند الخاسبي - فيما أرى - أن التعريف الأول عام يشمل كل المخلوقات العاقلة ، فالله سبحانه وتعالى أعطى العقل للجميع ، وميز البعض بالفهم ، وأزال عن مسلوب العقل صفة العاقل، ووصفه بالجنون ، فهو غير مكلف لذهاب عقله. وعلى ذلك فالعقل غريزة عامة في المخلوقين بها يفهمون ما يسمعون من أمور

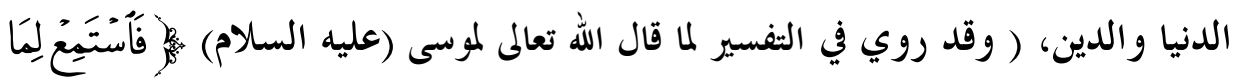

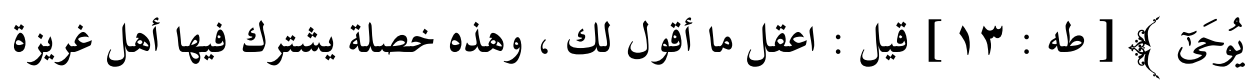

$$
\begin{aligned}
& \text { انظر : مائية العقل ص ץ • r بتصرف . }
\end{aligned}
$$

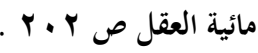

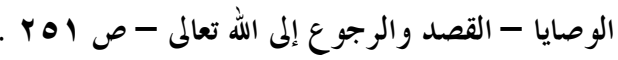




\section{منهـج الإمـام المحاسـبي في الوصسول لليقسين}

العقل التي خلقها الله فيهم من أهل المدى وأهل الضلالة من بعض أهل الكتاب لما تقدم عندهم من أهل الدين ، ويجتمع عليها أهل كل اييمان وضلال في أمور الدنيا خاصة ، والمطيع والعاصي ، وهو فهم البيان ) (1) . ( و وبميع الممتحنين المأمورين من العقلاء البالغين كلهم لهم عقول يميزون بها أمور الدنيا كلها ، الجليل والدقيق ، وأكثرهم للآخرة

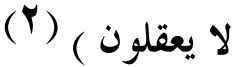

وأما التعريف الثاني فيمثل عند الخاسبي الطائفة التي عقلت وفهمت البيان ، ثخ

تفضل الله تعالى عليهم بزيادة العقل عنه سبحانه وتعالى، ووفقهم للعمل بما عقلوا (بَ). فهم جمعوا بين عقل الغريزة ، وعقل الأنوار ، وهذا التفضل منه سبحانه وتعالى عليهم ليس عن اجتهاد منهم في العقل عن الله تعالى ، بل هو بمجرد طلبهم ، وسعيهم في تحقيق النجاة ، وإدراك صحيح المعرفة ، و التفكر والاعتبار .

فإنه سبحانه وتعالى بعد أن أعطى عقل الغريزة لكل خلقه (استخلص من عباده خالصة من حلقه فهمت عنه قوله بعقولها ، فاتسع لها ما خفي عن الأبصار ، فآمنت به وبما غيبته حجب غيوبه من لدن عرشه إلى منتهى علمه ، ثم عارضها هاجس الثك فأبته وذلك بلطف البصير ، وما وصفه لها وبفضله عليها ، فكان عندها ما أخبر به عما غاب

مما كان ومما هو كائن كر أي العين فكانت بذلك مصدقة غير مكذبة ولا مرتابة ) (ع). ولا يقف الأمر عند هذا الصنف ، بل إن الخاسبي يتحدث عن صنف آخر أرقى

$$
\begin{aligned}
& \text { مائية العقل ص ^• ^ ـ . } \\
& \text { نفسه ص V.Y . . . } \\
& \text { نفسه ص YIV } \\
& \text { فهم القرآن ص Vצץ . . }
\end{aligned}
$$




\section{منهــج الإمـام المحاسـبـي في الوصــول لليقـين}

من الأول اصطفاهم الله تعالى واختصهم منهم قائلا : ( ثم استخص من الخالصة الأولى خاصة ثانية من المقرين والمعترفين له بربوبيته المصدقين بقوله ، فعظموا قدره ، فأجلوه وهابوه واستحيوا منه ، وخافوه وحذروا نقمته وبأسه ، فنطهروا من كل دنس ، وبذلوا له الجهود من قلوبهم وأبدانم ، ووصفوه بصفاته الكاملة ونزهوه من كل ما لا يليق ، و أفردوه في كل معنى ولم يساووه بشيء من خلقه ، فأفردوه بالمخافة والرهبة ، والآمال والرغبة ، والثقة به وحسن التوكل عليه فأعتقوا من خدمة الدنيا أبدافم ، وأفردوا مولاهم بالمعاملة بإخلاص النية له بطلب مرضاته واجتناب مساخطه وأيقنوا بما وعد وتوعد به فكان عندهم كرأي العين ، سلكوا سبيل الرشاد بالبصائر النافذة على منهاج الكتاب والسنة (1) ) ، فبانوا من عوام المسلمين بالفضل والطهارة فكانوا أئمة المدى و أعلام المتقين ومصابيح العلم ، ومفزع كل ملهوف في الدين وطالب لسبيل النجاة ) (T) . وذلك كله بسبب فهمهم عن الله تعالى ، فإنه سبحانه لم يعطهم ( اليقين به وبما قال عن رؤية منهم لربهم ، و لا معاينة منهم لما وعد وتوعد ، ولكن عن الفهم بما قال جل وعز في كتابه بالتذكير والتفكير والتثبيت والتدبير ، فرددوا النظر وأجالوا الفكر وكرووا الذكر ، وتدبروا العواقب ، وطلبوا معاني الدلائل ، فطالعوا الغيوب وشاهدوا بقلوبهم الآخرة فصاروا في الدنيا بأبدافم وفي الآخرة بأرواحهم وأجسامهم فيها كعو اد

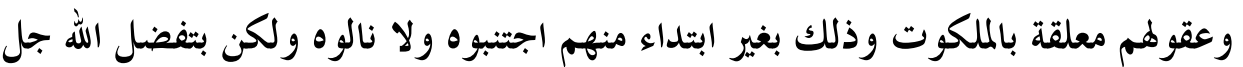

$$
\text { (ب) وعز عليهم وتعبده إياهم ) }
$$

وبذلك يظهر جليا أن العقول عند الخاسبي تبدأ في طريق طلبها للمعرفة بالغريزة

يؤ كد الخحاسبي دوما على ضرورة العمل بما شرع الله تعالى ، و إعمال الفكر في الكتاب والسنة ، وليس

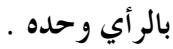

$$
\begin{aligned}
& \text { فهم القر آن ص ش\ץ ـ بتصرف يسير . }
\end{aligned}
$$

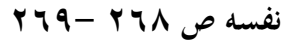




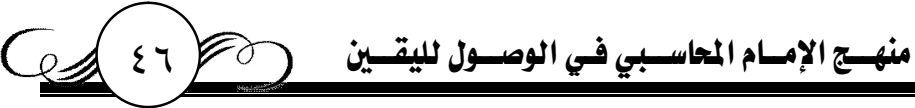

التي وضعها الله فيها ، ثم يدرك الله تعالى بعض عباده بلطفه ، وفضله ليميزهم عن بقية خلقه بالعقل عنه سبحانه وتعالى ، وفهم مر اده .

فالعقل في بداية المعرفي كسبي مجرد عن الهوى ، وفي فاياتحا وهبي بفضل الله تعالى ، وقد أكد الإمام الخاسبي على هذا الأمر في أكثر من كتاب ونص له ـ فيقول : ( ومن الهن

أراد الله به خيرا وهب له العقل ، وحبب إليه العلم ) (1)

ويطبق هذا المعنى على واحد من معاني العقل ، وكيف يرتقي العقل من طلب المعرفة إلى تحقيقها ، فيتحدث عن العقل بأنه : ( البصيرة والمعرفة ، بتعظيم قدر الأشياء

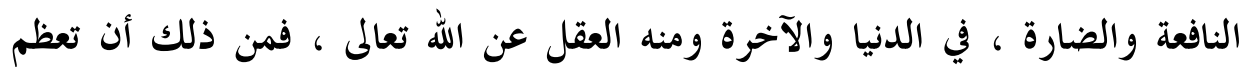
معرفته وبصيرته بعظيم قدر الله تعالى ، وبقدر نعمه وإحسانه ، وبعظيم قدر ثوابه وعقابه لينال به النجاة من العقاب والظفر بالثواب ) (؟َ). تم يعدد الخاسبي المترتبات الناتجة عن ذلك قائلا : (فإذا كان لله معظما كان لله مجلا هايبا ، وإذا كان الله مجلا هايبا كان منه مستحيا ، وإلى طاعته مسارعا ولمساخطه مجانبا ، وإذا كان معظما لما ينال به النجاة من العقاب والظفر بالثواب عني بطلب العلم ورغب في الفهم والعقل عن الله عز وجل أكثر همثله( ') ، وإذا عني بطلب العلم بذلك استدل به على عظم قدر المولى وقدر ثوابه وعقابه ، وإذا استدل على ذلك أبصر وفهم حقائق معاني البيان ، فإذا فهم عقل عظيم قدر الله تعالم وعرضه على الله سبحانه وعقابه وثوابه ، وإذا عظم قدر ذلك هاب الله وفرق ورجا ورغب واشتاق فكأنما يعاين ذلك كرأي العين ، فكان عن الله تعالى عاقلا

$$
\text { مائية العقل صالة المسترشدين ص . } 197 \text {. } 19 .
$$

يؤكد الخاسبي في هذا النص - مؤكدا ما سبق قوله - على ضرورة طلب العلم ، والرغبة في الفهم المنبعثة ذاتيا من داخل الباحث ، مع ضرورة تحديده المسبق للمعرفة المراد بحثها . 


\section{منهـج الإمـام المجاسببي في الوصسول لليقسين}

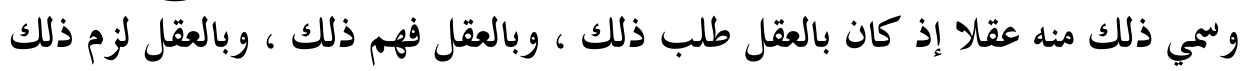

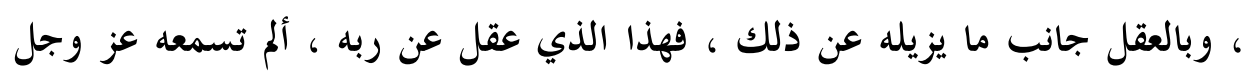

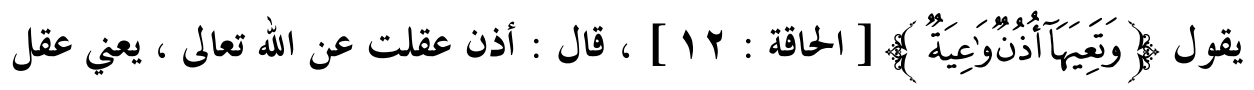

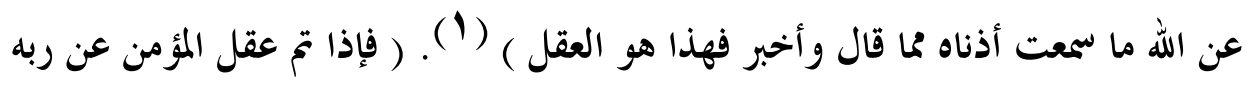

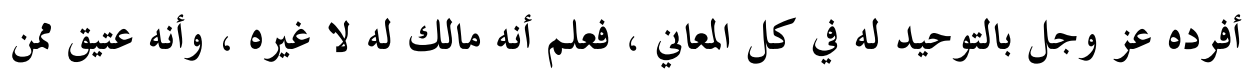

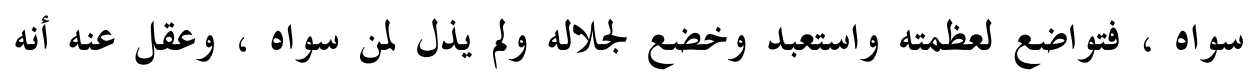

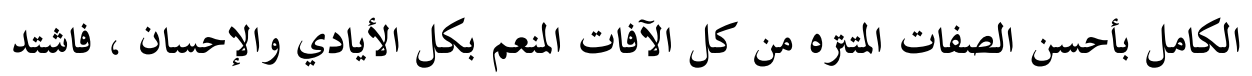

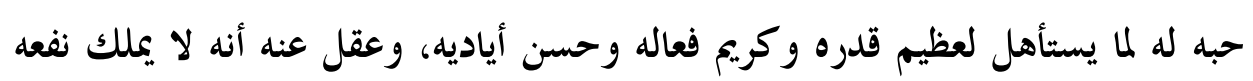

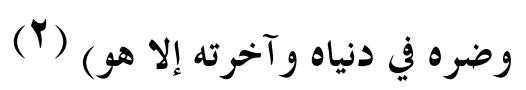

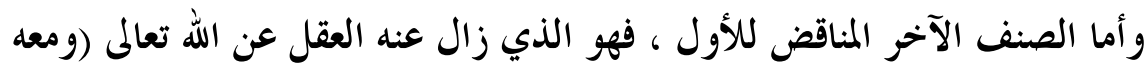

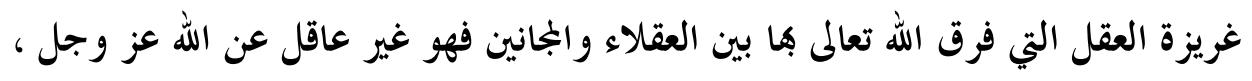

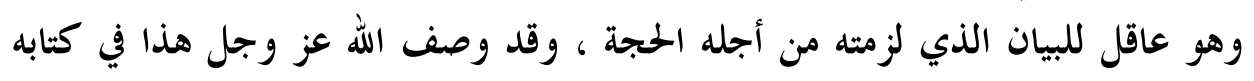

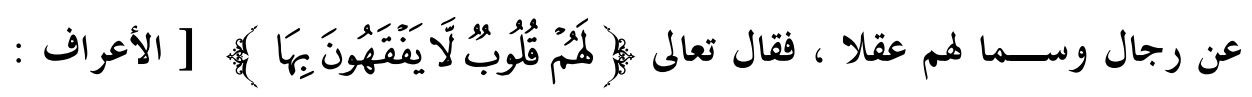

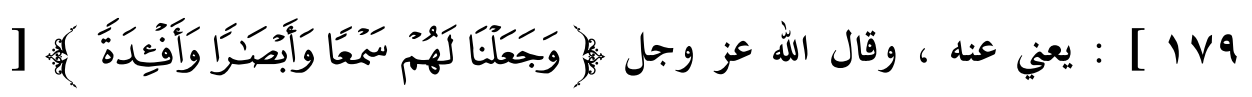

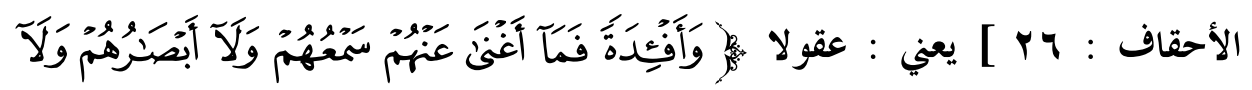

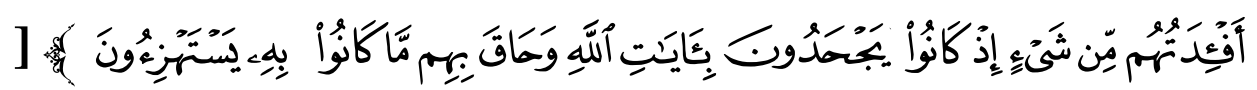

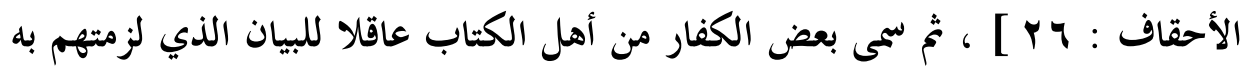

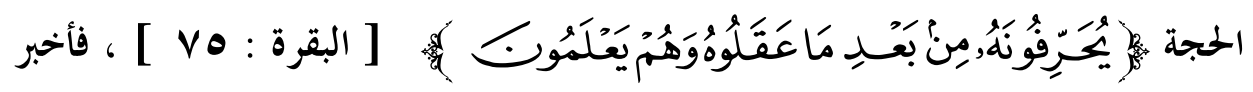

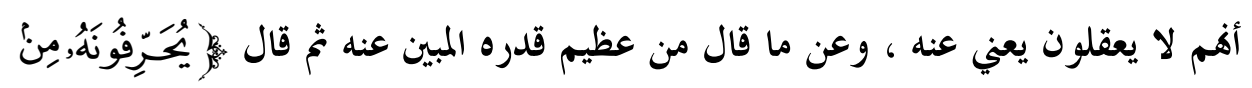

$$
\begin{aligned}
& \text { مائية العقل ص I| P . } \\
& \text { مائية العقل ص ا Y P }
\end{aligned}
$$


منهـــج الإمسام المحاسبـي في الوصسول لليقسين

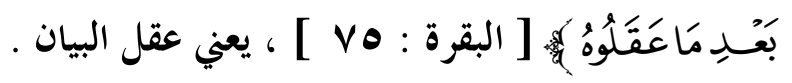

وآخرون لهم عقول الغرايز لا يعقلون البيان ، ولا المبين عنه بالفهم له إلا أنم

يسمعون بلغة يعرفوفا كلاما لا يعقلون معانيه بالفهم له ، كمشركي العرب فقال : إنإن

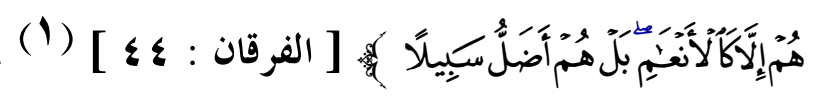

وعود ذلك كله عند الخاسبي راجع لاتباع الهوى ، الذي به صارت عقولهم غير

مجردة، وهم في بداية مرحلة الطلب المعرفي ، فهؤلاء قد ركب الله فيهم عقول ، وعلى اله الرغم من ذلك ( فإنمم لم يعقلوا ما قال الله عز وجل ؛ لإعجابهم برأيهم ، ولتقليدهم

$$
\text { آباءهم و كبر اههم ، وقد كانت لهم عقول غرايز يعقلون بها أمر دنياهم ) (Y). }
$$

ويحدد الخحاسـبي علاج هذا الداء بضرورة البعد عن الهوى ، فهــؤلاء ( لو تركوا الإعجاب بالرأي وتقليد الكبراء ، ثم تدبروا لعقلوا ما قال الله ، ولكن أعجبوا

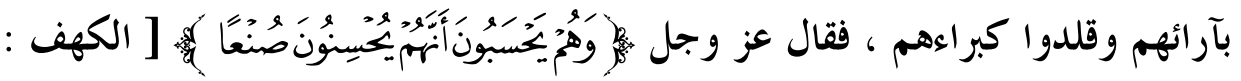
(r) $[1 \cdot \varepsilon$

وبهذا النص الأخير تتأكد ضرورة ملحة أكدها الخاسبي في كامل منهجه في بحثه عن اليقين ، وخاصة من خلال العقل ، وهي إسقاط الهوى حتى يتسنى صحيح النظر ، و أن اتباع الهوى هو أساس الضلال في الأديان ، وهو أساس الخطأ في التفكير . فإذا أسقط الباحث هواه الذي علق بعقله من تصورات سابقة ، أو أحكام مسبقة

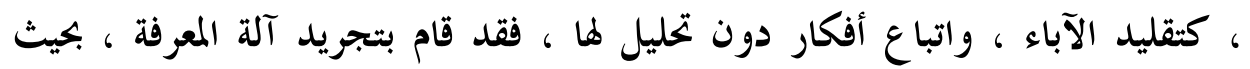

$$
\begin{aligned}
& \text { مائية العقل ص TTM Y . . } \\
& \text { نفسه . } \\
& \text { نفسه ـ وانظر ص O P }
\end{aligned}
$$




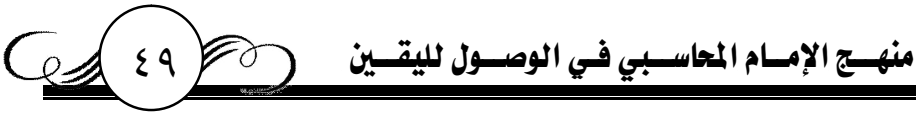

يستطيع أن ينظر بها نظر ا مجردا يصل فيه إلى نتائج صحيحة ( (1).

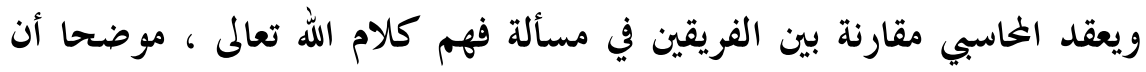
الذي أسقط الهوى استوضح مفهوم كلام الله تعالى في كتابه عكس من اتبع الهوى وآثره ، فيقول : (فلما عقلوا ذلك عن ربهم ابتغوا منه الثفاء والمدى والرحة ، فداووا به قساوة قلوبهم ، وغسلوا به درن ذنوبهم ، ووضعوا دواءه على أدواء قلوبهم ، ونفوا به سوء النيات من ضمائرهم ، وأزالوا به وحر صدورهم ، ونظروا ببصائرهم إلى ما يشبه الثبهات من سوء الدلايل ، ومكايد الشيطان ، وزخرف المبطلين ، و كشفوا بمنار دلايله ما وارته الظلمات ، وغطته الشهوات من خفيات الغيوب ، ومعالم الطريق المضروب على المحاج الواضحات والبرهان النير ، فنظروا بنور هداية كلام الرب جل ذكره ، وواضح دلايله إلى ما خفي عن الغافلين المؤثرين لأهو ائهم على استيضاح كتاب ربمى جل

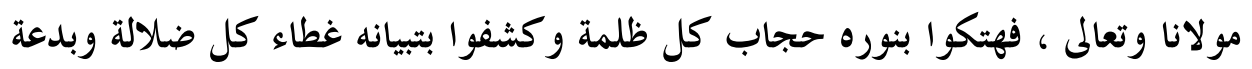
؛ لأنه الدليل الواضح والصراط المستقيم الذي جعله الله للناس إماما ورضي به بينهم

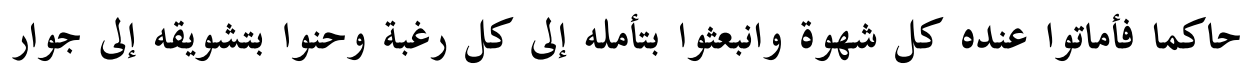

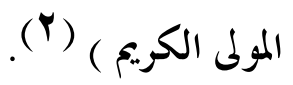

يعتبر الخحاسبي سباقا في هذه المسألة متأثرا بالقر آن الكريم ، وسنة النبي ( صلى الله عليه وسلم ) على كثير من الفلاسفة الذين جاؤوا بعده كبيكون حين قسم الأوهام التي تعوق عن الوصول عن الحقيقة

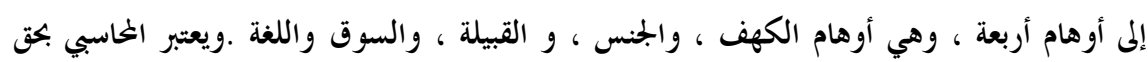

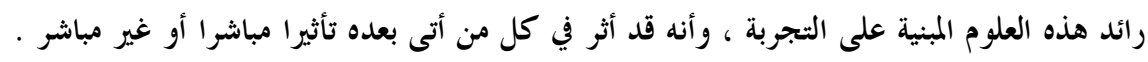

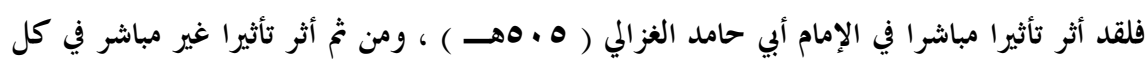

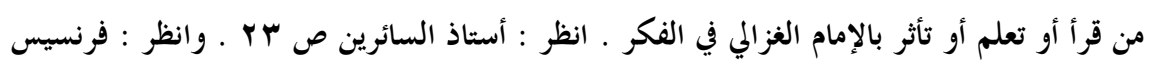

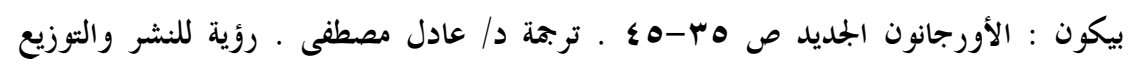

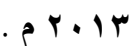

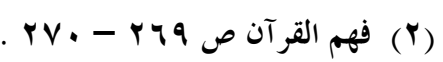


حدود العقل

إذا كان العقل هو آلة المعرفة ، وهو في بداية المعرفة والبحث عن اليقين كسبي ،

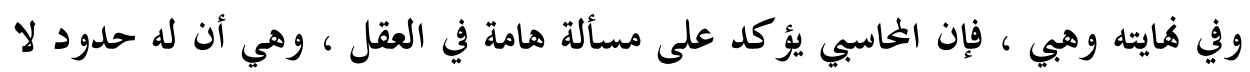

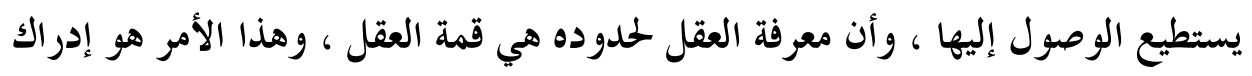

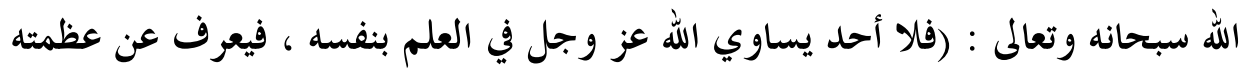

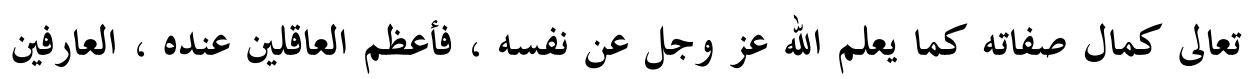

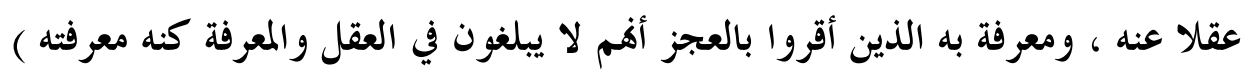

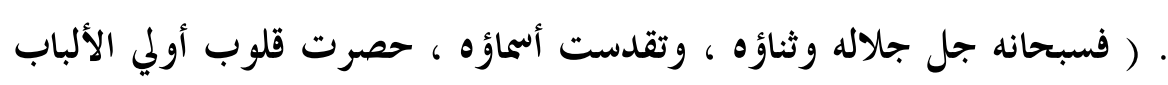

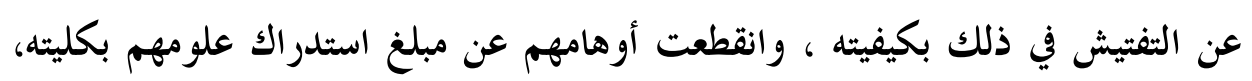

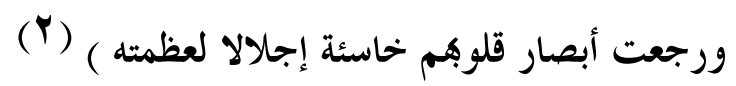
وبذلك تكون القسمة المنطقية للعقلاء من حيث الفهم عن الله تعلى ، وتجريد آلة المعرفة عند الخاسبي قد اكتملت ، وهي عنده أربعة اقسام . أقسام العقلاء : القسم الأول : فرقة عقلت عن الله تعلى عظم قدره ، وقدرته وما وعد وتوعد

فأطاعت وخشعت (r) القسم الثاني : وفرقة عقلت البيان ، ثم جحدت كبرا وعنادا لطلب الدنيا ، كما

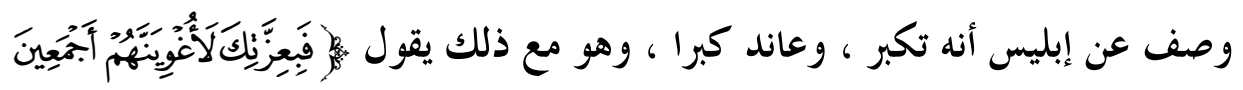

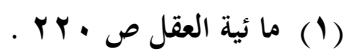

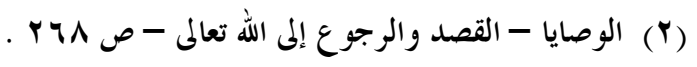

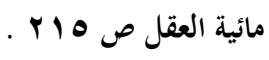




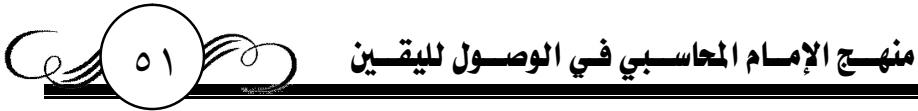

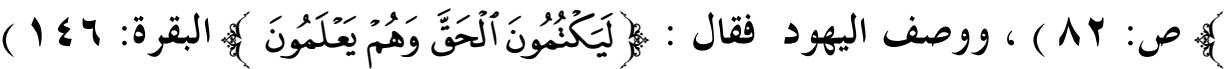

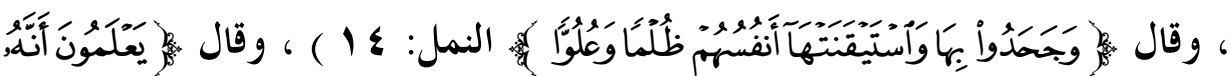

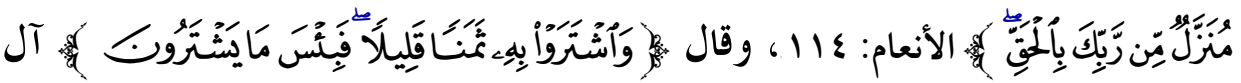

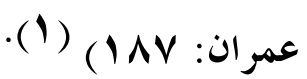

القسم الثالث : وفرقة طفت وأعجبت ، وقلدت فعميت عن الحق أن تتبينه ، ثم

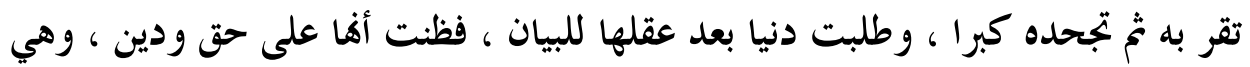

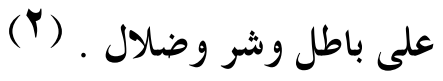

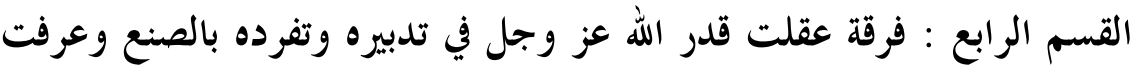

قدر الإيمان في النجاة بالتمسك به ، وقدر العقاب في ضرره في مجانبة الإيمان ، فلم

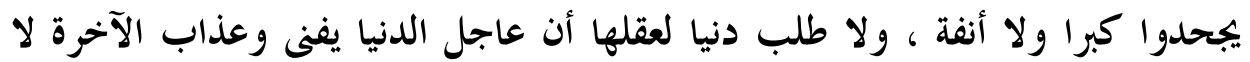

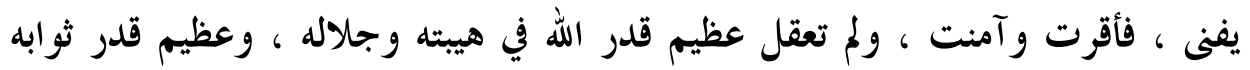
وعقابه في إتيان معاصيه ، و القيام بفرايضه ، فعصت وضيعت وغفلت ونسيم ونسيت إلا أفا علمت عظيم قدر الإيمان في النجاة وعظيم ضرر الكفر قد عقلته عن الله تعلى فهي قائمة

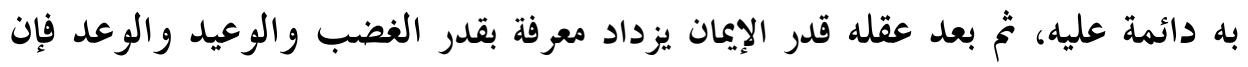

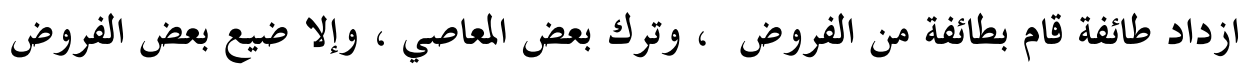

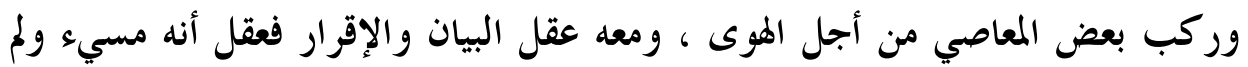

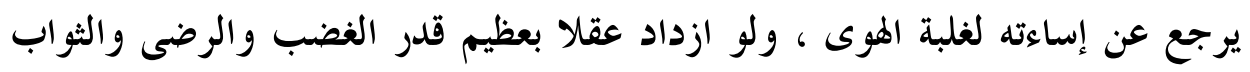

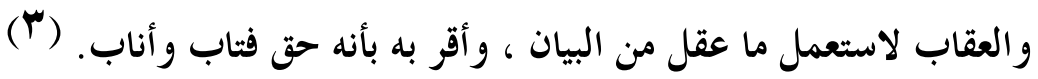

$$
\begin{aligned}
& \text { (1) (1) }
\end{aligned}
$$

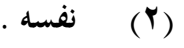

$$
\begin{aligned}
& \text { نفسه ص YIV-Y IIV }
\end{aligned}
$$




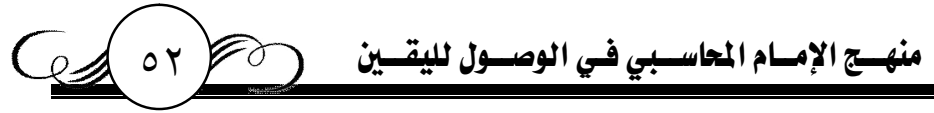

ومتى يسمى الرجل عاقلا عن الله تعالى ؟ : يجيب الخاسبي بأنه يكون عاقلا عن الله تعالى إذا كان مؤمنا خائفا من الله عز وجل ، و والدليل على ذلك أن يكون قائما بأمر الله تعالى الذي أوجب عليه القيام به مجانبا لما كره وفهاه عنه ، فإذا كان كذلك استحق أن يسمى عاقلا عن الله تعالمى (1) . أقسام العقل عند الخاسبي

قسم الخاسبي العقول من حيث الفهم في كثابه مائية العقل إلى عقول غرايز(Y) ،

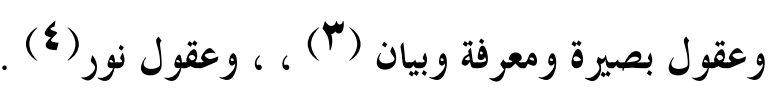

لكنه عاد وقسمها تقسيما إدراكيا مرة أخرى في كتابه القصد والرجوع إلى الله تعالى إلى قسمين : ( عقل غريزة ، وعقل تجارب ، فالغريزة أدركت التجارب ، وبالتجارب عقل أن العقل عاقل ) (•) وهذا النص يوضح أن المنهج الذي سلكه الغحاسبي ويراه سبيلا للوصول لمعرفة حقيقية يقينية ، دون شك وارتياب ، هو المنهج التجريبي . وبالذي سبق تقريره يتضح أن تصحيح أو تجريد آلة النظر والمعرفة عند الخحاسبي

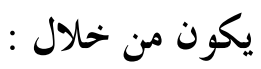

$$
\begin{aligned}
& \text { (1) (1) نفسه صו (1) }
\end{aligned}
$$

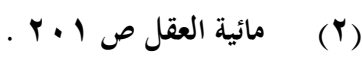

$$
\begin{aligned}
& \text {. P : (Y) }
\end{aligned}
$$

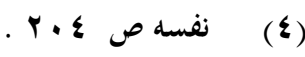

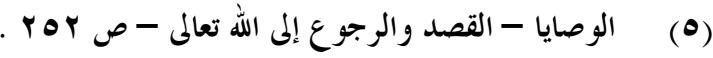

$$
\begin{aligned}
& (v \cdot \lambda)
\end{aligned}
$$




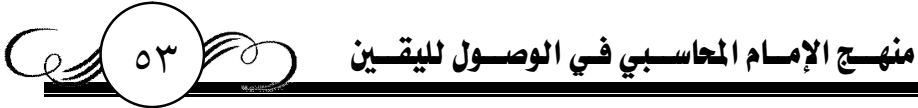

1- تحديد المعرفة المراد البحث عنها ، سواء كانت معرفة عامة كالبحث عن النجاة ، أو معرفة خاصة كالبحث عن كيفية كلام الله تعلى ، ومر اده من كتابه الكريع .

ץ- طلب المعرفة، والاجتهاد في البحث عنها بالعقل، يقول الخاسبي: (واعلم أن ما يصل

العبد إليه من الفهم بقدر تقديم عقله، وموجود علمه بتقو اه لله وطاعته ) (1)

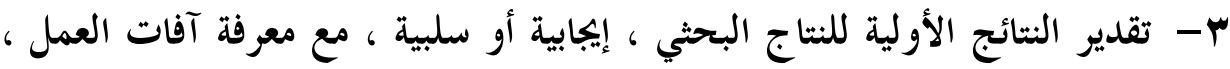
يقول الخاسبي : (فمن كانت له عناية بنفسه ، وخاف عليها التلف طلب لطائف الأسباب بدقائق الفطن ، وغائص الفهم حتى يصل إليها ، فإذا وصل إليها تمسك

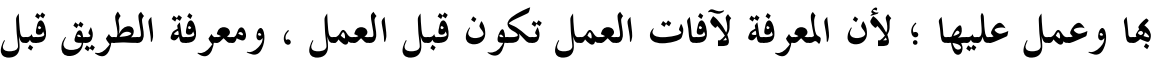

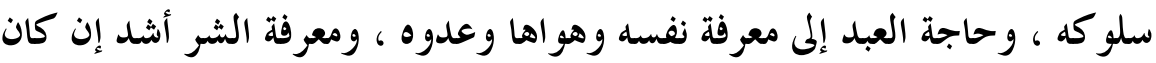

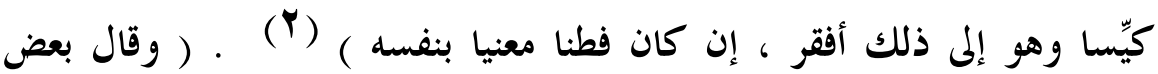
الحكماء : إذا أردت أن يكون العقل غالبا للهوى ، فلا تعجل بقضاء الشهوة حتى الثى تنظر في العاقبة ، فإنه كان يقال : إن مكث الندامة في القلب بارتكاب الشهوة

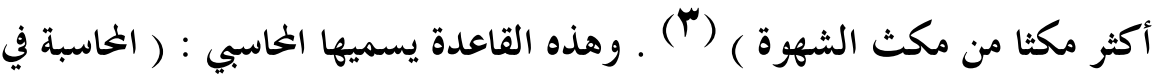

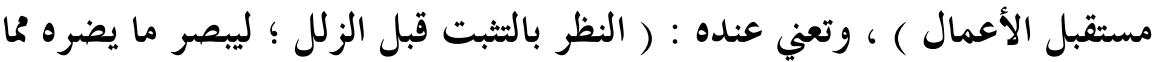
ينفعه ، فيترك ما يضره على علم ، ويعمل بما ينفعه على علم ، فمن اتقى العجلة

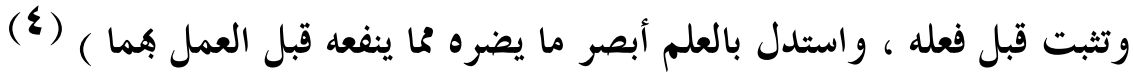

$$
\begin{aligned}
& \text { رسالة المسترشدين ص به . ـ وانظر آداب النفوس ص . 1 . }
\end{aligned}
$$

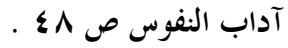

$$
\begin{aligned}
& \text { الرعاية لحقوق الله ص V؟ ـ ل }
\end{aligned}
$$

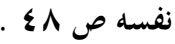




\section{منهـج الإمسام المحاسببي في الوصسول لليقسين}

ويستدل الإمام الخاسبي على ذلك بأهل الأعمال في الدنيا ، وكيف يخرج العمل

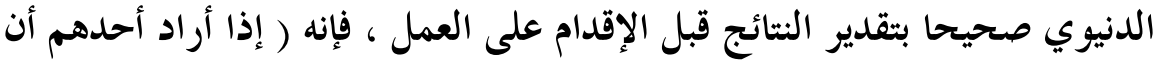

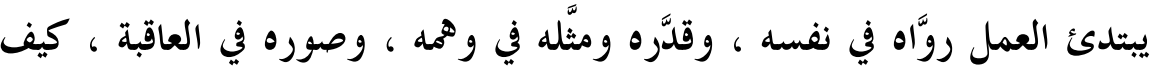
يكون إذا فرغ منه ؟ فإذا تمثل في وهمه على ما يريد من الإحكام والتمام ابتدأ فيه ،

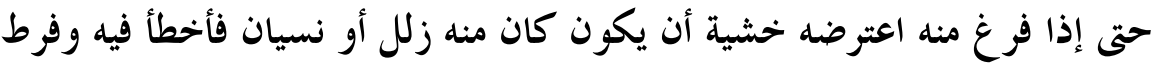
في إحكامه ، فإن رأى تفريطا أتم ما بقي منه وأصلح ما فسد منه ) ( ') ع- إسقاط الهوى والعاطفة ، وكل معوق يعوق العقل عن الوصول الحقيقي للمعارف

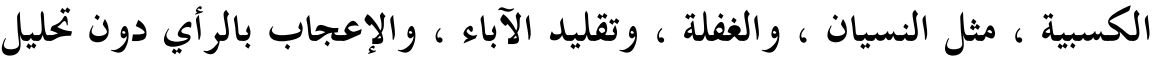

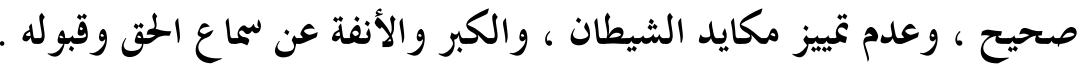
ه- العمل على ضرورة ترك الإعجاب بالرأي : لأنه من أعظم معوقات العقل عن

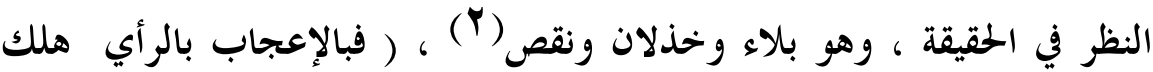
عامة الكفار وأهل البدع من أهل الإسلام ، وأهل الحطأ في الفتيا ؛ لأفم تأولوا فأعجبوا بتأويلهم ، وظنوا أنه الحق اليقين ، وقاسوا على غير القياس ، فأعجبوا

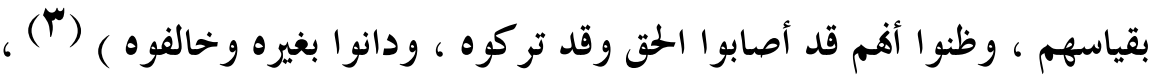
( واستحسان الرأي الخطأ يأتي من قبل هوى النفس ، مع اعتراض من الظن أنه حق النق

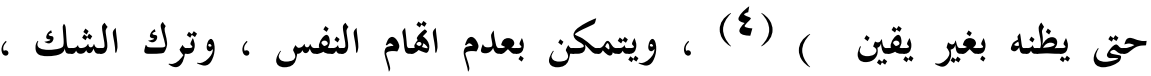

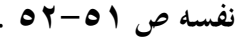

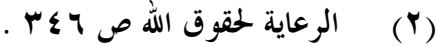

$$
\text { نفسه ص ن }
$$




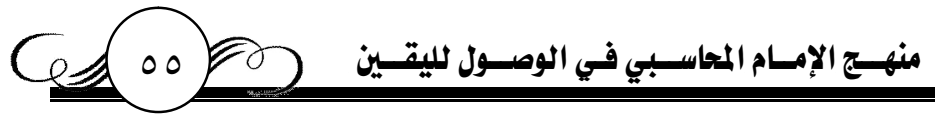

واستحسان الرأي بغير علم واضح ، ولا دليل عليه من الله عز وجل (1).

צ- معرفة قواعد كل علم قبل البحث فيه ، فينبغي للباحث عن اليقين في العلوم حال

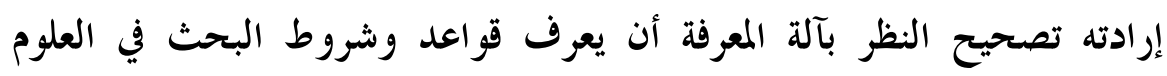

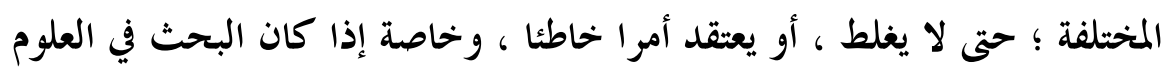

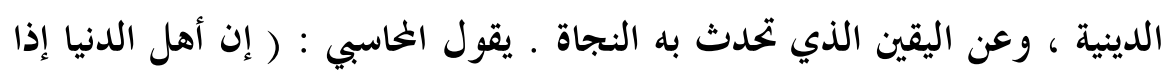

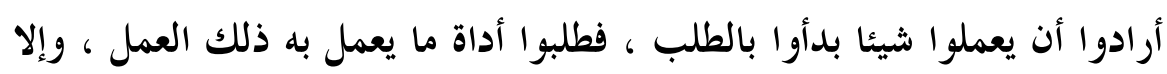

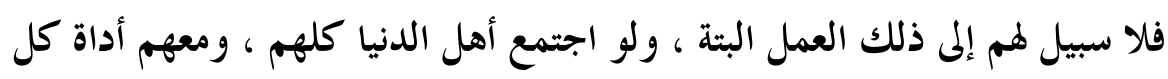

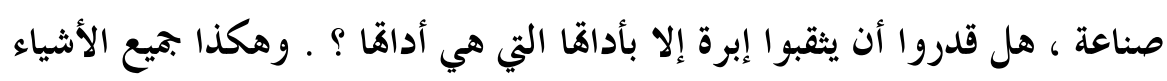

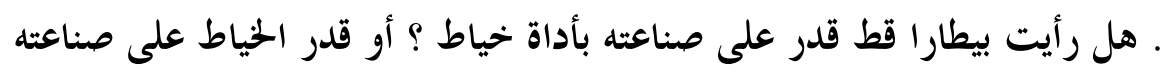

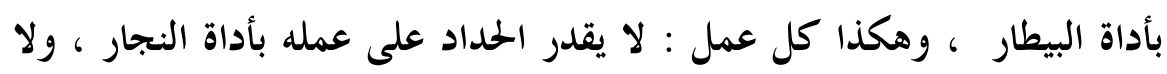

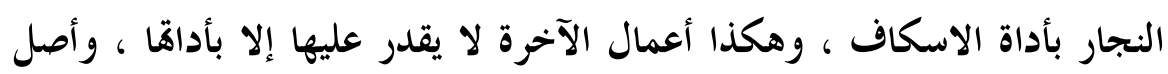
أداة أعمال الآخرة العلم والمعرفة والاعتبار فإفا من دلالات الأداة ) (َّ). - V - مع العقل وتحديد النظر مع ترك الانشغال بغير المعرفة التي هي قيد التحصيل :

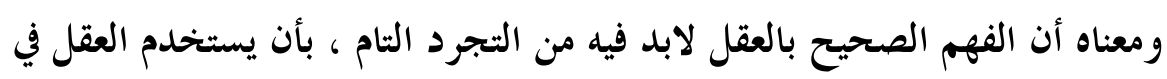

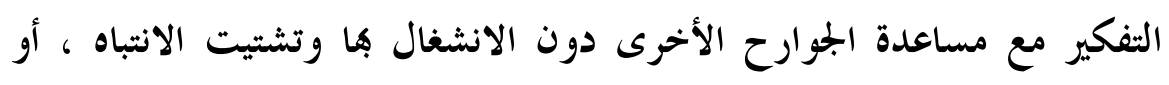

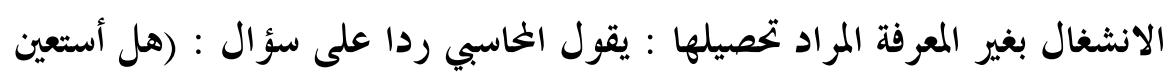

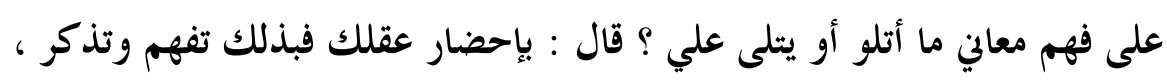

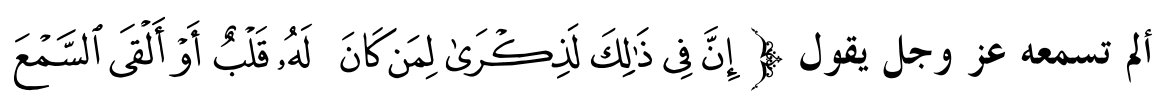

نفسه ، وقد تمت الإشارة في أثناء الحديث عن مراحل الشك الأولية عند الإمام الخاسبي أن ترك الشك وترك قمة النفس من العوائق عن النظر الصحيح ، والوصول لليقين .

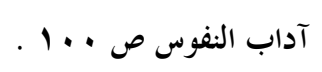




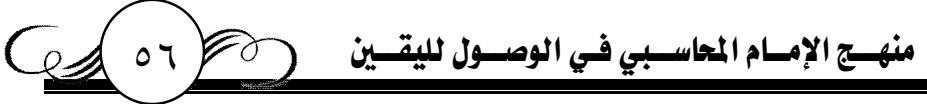

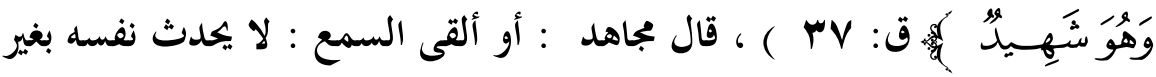
ما يسمع ، وهو شهيد : قال شاهد القلب .

قلت : فكيف أحضر عقلي حتى يكون شاهدا لا يغيب عن فهم كلام ربي جل وتعالم ؟ قال : بأن تجمع فهمك حتى لا يكون فهمك متفرقا في شيء غير طلب

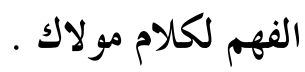

قلت : و كيف أجمع همي حتى لا يتفرق في شيء سوى ذلك؟ قال : تمنع عقلك من النظر في شيء سوى طلب فهم كتاب ربك جل وتعالم.

قلت : وكيف أبمع عقلي ؟ قال : بأن لا تشغل جوارحك بما لا يشتغل به عقلك ، وأن تستعمل كل جارحة بما يعينك على الفهم كنظرك في مصحف ، ، و واستماعك له إلى تلاوتك أو تلاوة غيرك ، وتمنع عقلك من فكر وذكر يقوى طلب فهم كلام مولاك ؛ لأنك إذا لم تشغل جوارحك بشيء غير ذلك ، ومنع عقلك عن النظر والفكر في غير ذلك اجتمع همك وحضر ، و إذا حضر عقلك زكا ذهنك ، و إذا زكا ذهنك قويت على طلب الفهم ، واستبان فيه اليقين ، وصفا فيه الذكر ، وقوي فيه الفكر ) ( (1) ، وهذا يقتضي التحصيل الحقيقي للمعرفة ، و الوصول لليقين فيها ( وبذلك مدح الله تعالى المستمعين لتلاوة كتابه بالفهم ، فقال عز وجل : عز وجل ، مدحهم بأن سكتوا عن الكلام ؛ لئلا يشتغلوا عن فهم ما يتلو نبيه عليه

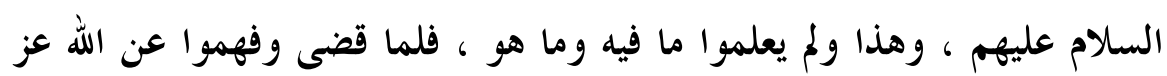

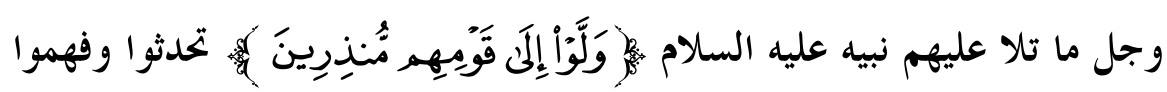




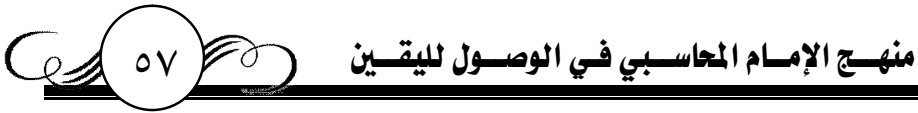

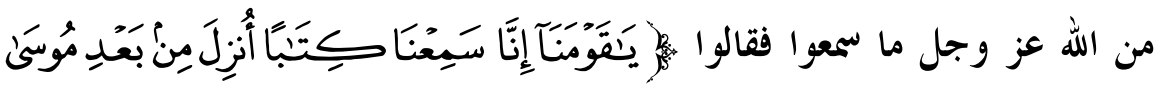

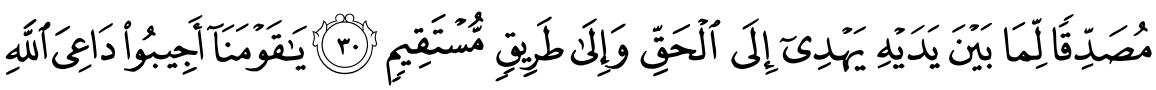

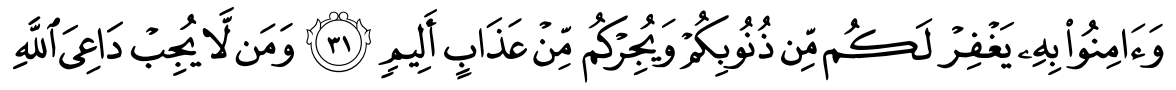

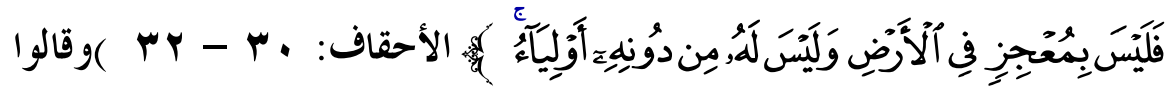

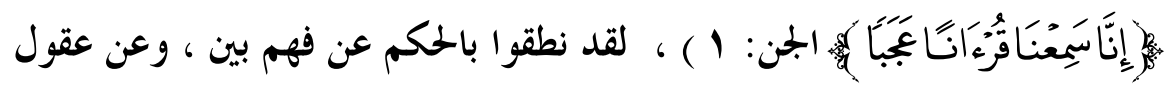
ذكية في استماع آيات في مقام واحد فدعوا إلى إجابة الله عز وجل وأملوا المغفرة والنجاة من العذاب الأليم ، وأخبروا أنه من أعرض عما تلا نبيه صلى الله عليه وسلم من كلام ربه عز وجل لا يعرف الله ، وأن مصيره إليه . هذا الأدب والفهم من استماع آيات في مقام واحد في أقل من ساعة فكيف بمن وعى

$$
\text { القر آن كله من صغره ) (1) }
$$

^- طلب التوفيق من الله تعالم في المعرفة الدينية وغيرها ، فلولا توفيق الله تعالى لضل العقل في سعيه عن الحقيقة مهما أوتي من مقومات . وهذا التوفيق يناله العبد بعد

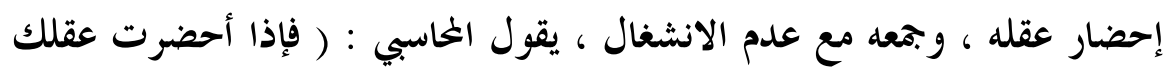
بجمع همك بنية صادقة مع أمل ورجاء أن تنال ما قال ، وتسارع إلى محابِّه ، وتجتنب مساخطه ، وتريده وحده ، ولا تريد أن تفهم منه ما تنصنع به عند العباد ، فإذا نظر الله عز وجل إليك وأنت كذلك ، وعلم ذلك من ضميرك أقبل بلطفه وولي تقويم عقلك بفهم كلامه ، وما فيه من علم الغيوب ، ومكنون الوعيد فحينئذ

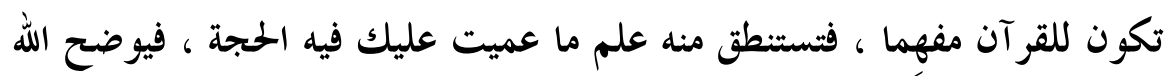
لك به البرهان ، ويمدك بالفوائد ، ويجلي عنك ظلم الثبه ، ويدلك على محجة

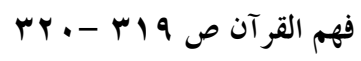




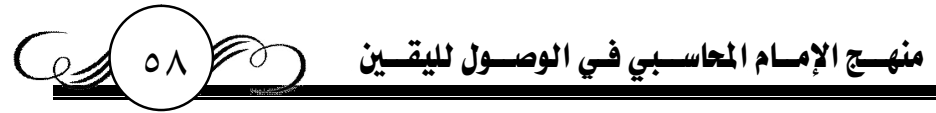

المهتدين ، ويذيقك الحلاوة التي أذاقها أهل التقوى ) ( '). ثم يقول : ( فإن طلبت

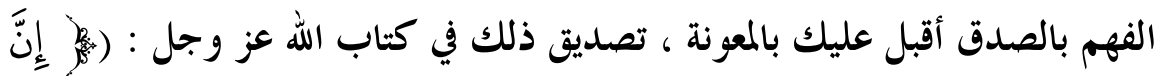

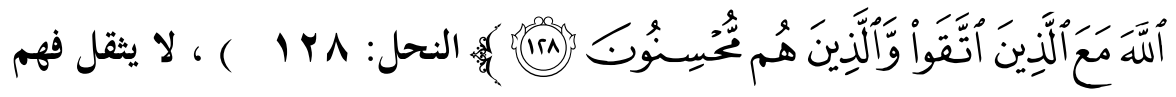

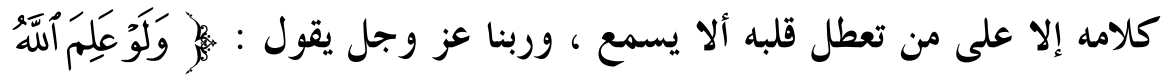

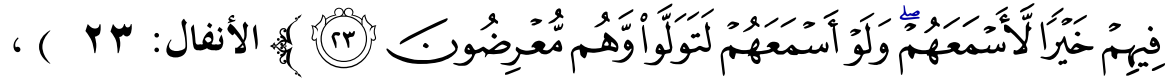

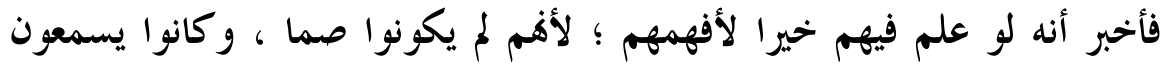

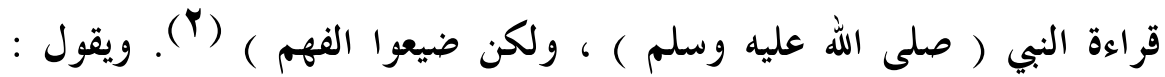

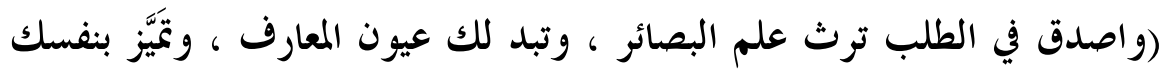
علم ما يرد عليك بخالص التوفيق ، فإنما السبق لمن عمل ، والحخشية لمن علم ، والتو كل لمن وثثق ، والحوف لمن أيقن ، والمزيد لمن شكر ) (") ). 9- التجربة وفهمها مع استقراء الحمالات السابقة ، يقول الخاسبي : ( فاطلب آثار من

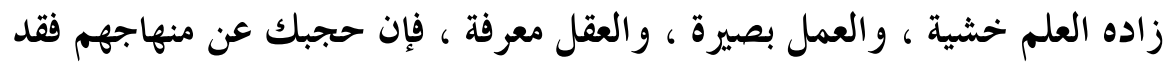
الأدب ، فارجع بالذم على نفسك ، ولن يخفى على أهل العلم صفة المخلصين )

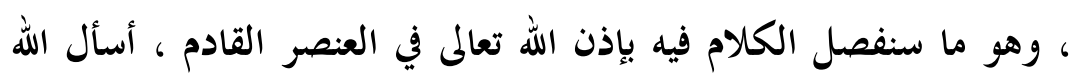

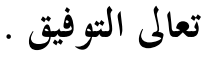

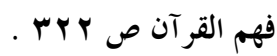

$$
\begin{aligned}
& \text { نفسه ص بrTr. } \\
& \text { رسالة المسترشدين ص ب9 ـ وانظر : آداب النفوس ص . . 1 . } \\
& \text { رسالة المسترشدين ص 1 1 - ب +1 . }
\end{aligned}
$$




\section{منهـج الإمسام المحاسـبي في الوصسول لليقـين}

\section{المرحلة الثالثة : الاستقراء والتجربة}

الاستقراء في اللغة : يعني التتبع ، من استقرأ الأمر إذا تتبعه ؛ لمعرفة أحواله .

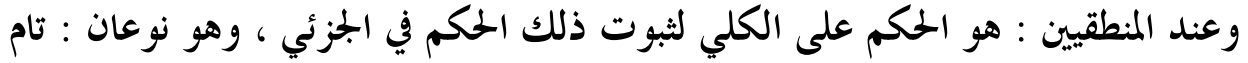
وناقص ـ فالتام هو الحكم على الجنس لوجود ذلك الحكم في جميع أنواعه كما قال

أرسطو . والناقص : هو الحكم على الكلي بما حكم به على بعض جزئياته (1).

والإمام الخاسبي يرى ضرورة الاستقراء التام لجميع أفراد الموضوع المراد بحثه ،

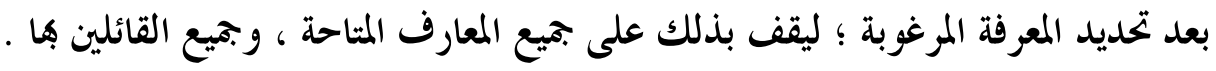

فبعد أن أعلن أنه انتهى إليه البيان بتفرق الأمة ، وأن الثك بدأ يتسرب إليه لعدم

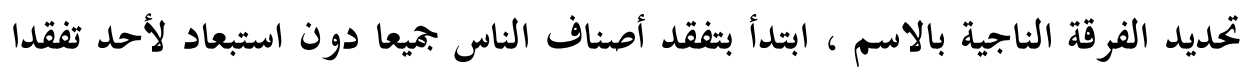

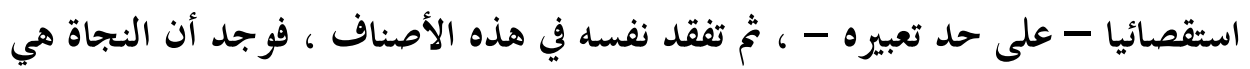

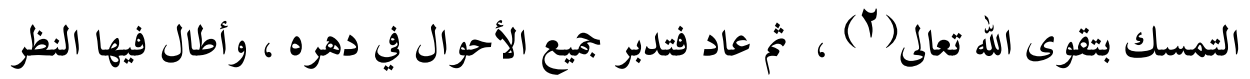

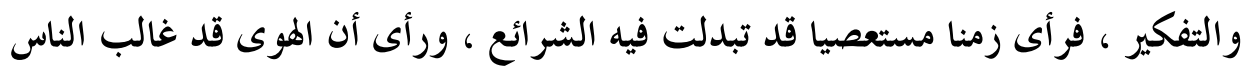
فاتبعوه(") ؛ ولأجل ذلك نادى بضرورة إسقاط الهوى ، وردد ذلك في كلامه كثيرا ،

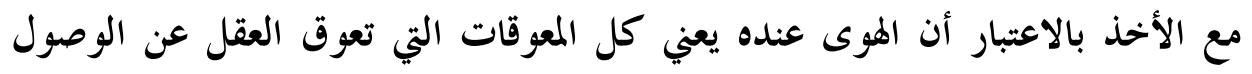
للحقيقة ، كالنسيان ، والشهوة ، والغفلة ، والتقليد الغير مستقيم . فهم التجربة

ثم يؤكد الخاسبي على أن سبيل الوصول للمعرفة اليقينية ، والتثبت منها ، يكون

$$
\begin{aligned}
& \text { (1) المعجم الفلسفي جـ اص VY V . }
\end{aligned}
$$

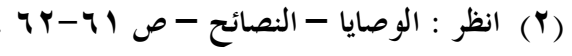

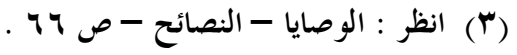




\section{منهـج الإمسام المحاسببي في الوصسول لليقسين}

من خلال التجربة ، وليس مجرد التجربة هو الذي ينادي الخحابي بتطبيقه للتمييز والفصل بين الحير والشر ، أو بين الحقيقة والباطل ، فإن الناس جميعا في نظره خحاضعون للتجارب لئري

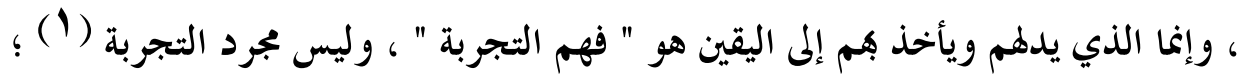
لأن فهم التجربة عند الخاسبي يؤدي إلى التفتيش الدائم ، واستقراء الأحوال السابقة

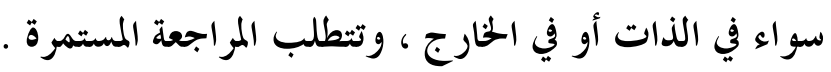

ولذلك فإن الناس في هذه القاعدة متفاوتون، وهم أقسام من حيث فهم التجربة : القسم الأول : أهل العناية الموفقون لفهم التجربة ، وهؤلاء هم العارفون المميزون

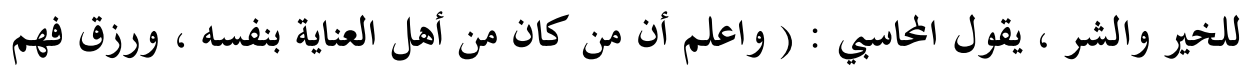

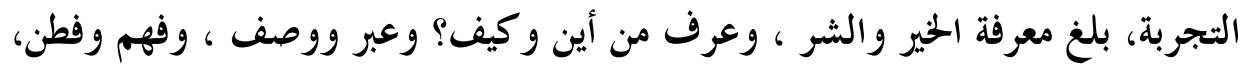

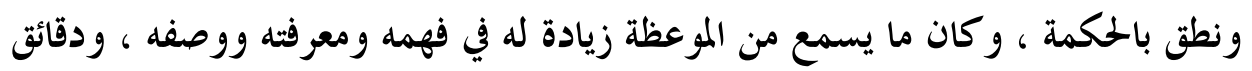

فنتنه وسر حاجته ) (Y)

وهذا النص السابق يؤكد على أن المنهج التجريبي عند الخاسبي هو المنهج الأمثل

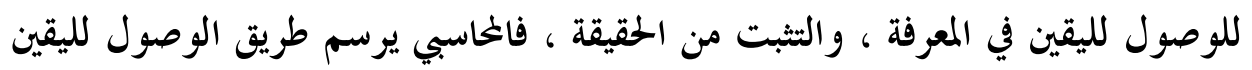
من خلال التجربة عن طريق :

أولا : الانتباه لطلب المعرفة ، والمثابرة في تحصيلها ، والانسان فيها يكون من أهل

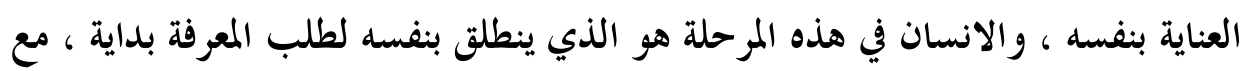

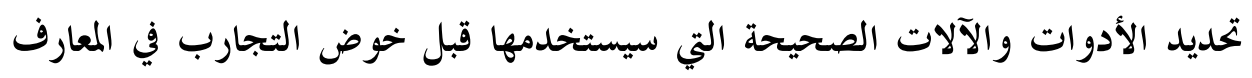

الناس متمعا عند الخاسبي متساوون في عطية العقل والتجربة ، فالله تعالى أعطى الجميع عقولا متساوية ، لكن ميز بعض عباده بعقل النور الذي يفهم ويعقل عن الله تعالم ، وأعطى للبعض أيضا فهم التهال

$$
\text { آداب النفوس ص التي خاضوها . }
$$




\section{منهـج الإمسام المحاسـبي في الوصسيول لليقسين}

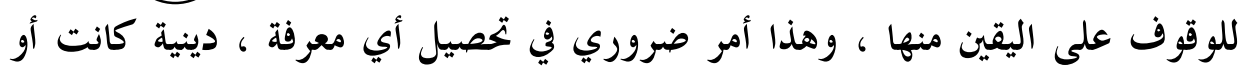

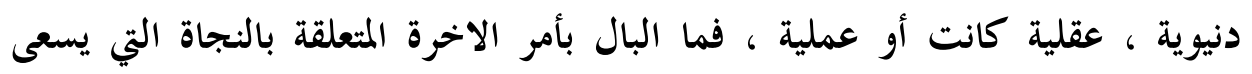

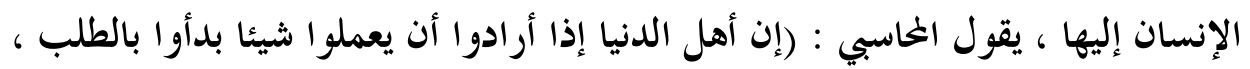

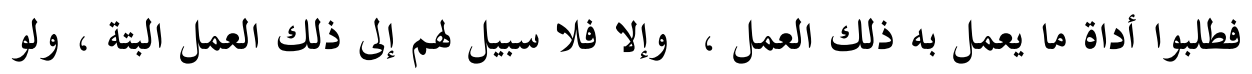

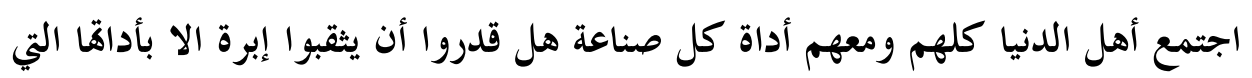

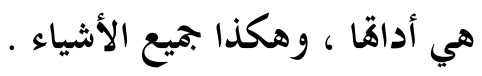

هل رأيت بيطارا قط قدر على صناعته بأداة خياط ، أو قدر الحياط على صناعته ألها

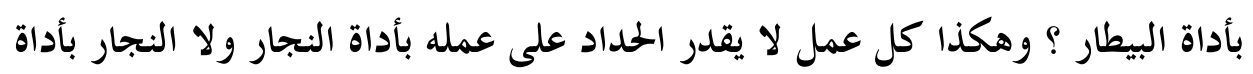

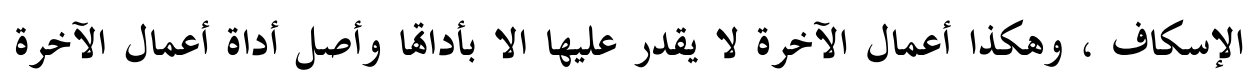

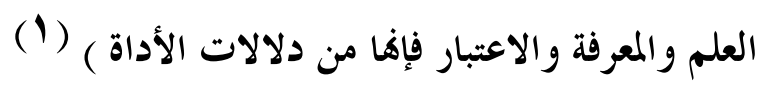

فلابد في طلب اليقين المعرفي من اصطحاب أدواته التي هي العلم والمعرفة

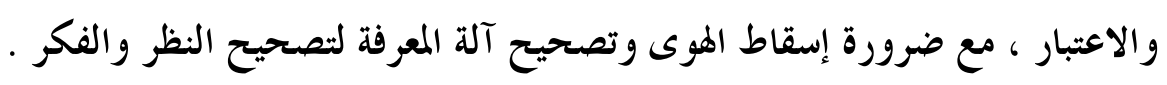
ثانيا : الاهتمام بالتجربة وفهمها ، والوقوف على قو اعدها الصحيحة .

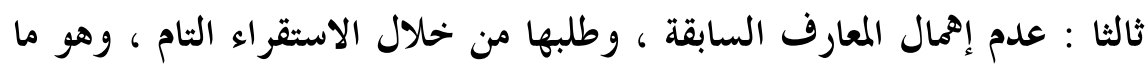

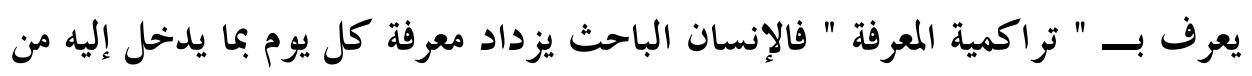

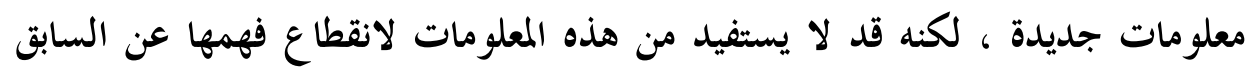

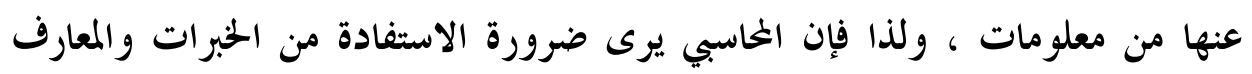

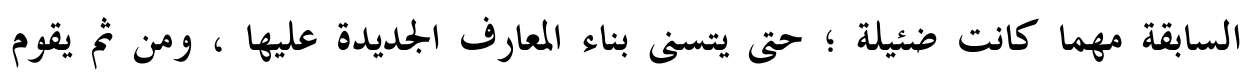

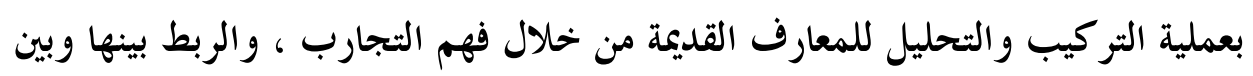
المعلومات الجحديدة .

$$
\text { آداب النفوس ص . .1 . }
$$




\section{منهـج الإمسام المحاسـبي في الوصسول لليقسين}

رابعا : التمييز بين الحير والشر يكون بمعرفة سببهما ، وكيفية حصولمما ، واختبار

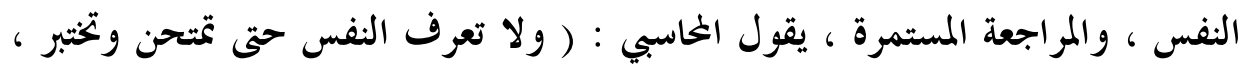

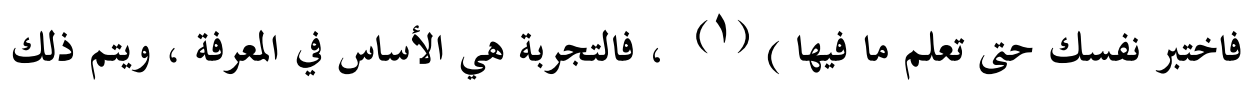

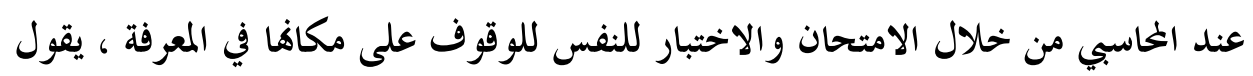

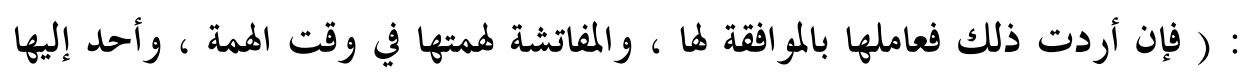

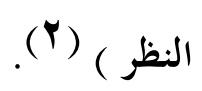

تم يضرب الخاسبي أمثلة على ذلك ، كالحلم وقت تعرض السفيه ، والتواضع

وقت التعرض للجفاء، والأمانة عند الهوى، والطمع وقت هيجان الرغبة وغيرها ("َ). تم يقول : ( فإن كنت في هذه الحالات والأوقات محمودا فما أحسن خيرك واحد

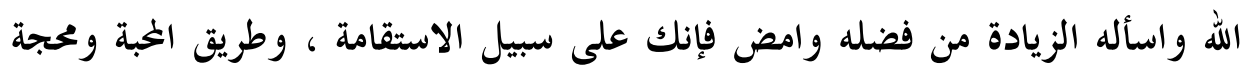

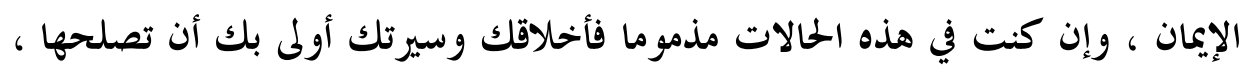

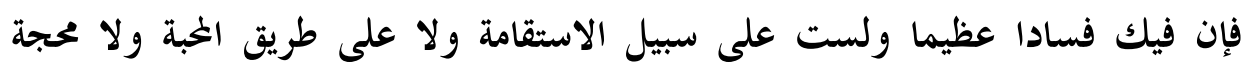

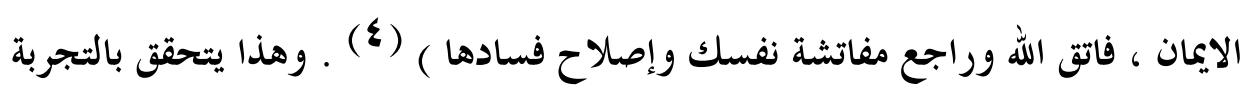

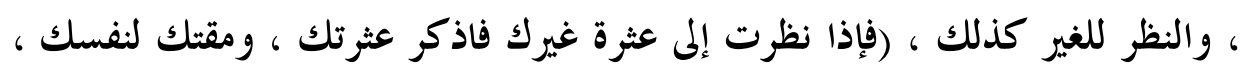

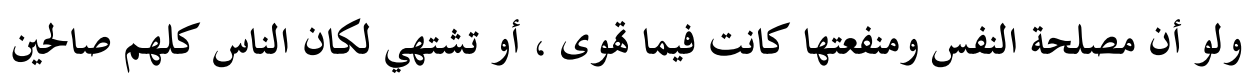
، ولكن جعل صلاحها فيما تكره، وفسادها فيما تحب وتشتهي ) (•).

$$
\begin{aligned}
& \text { آداب النفوس ص } 90 \\
& \text { (Y) (Y) } \\
& \text { انظر : آداب النفوس ص } 97 \\
& \text { نفسه . } \\
& \text { نفسه ص 9V }
\end{aligned}
$$




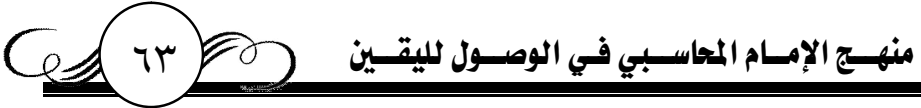

وملاك ذلك كله حاصل بالاعتبار الذي يشتمل على النظر، والتجربة وفهمها ،

$$
\text { فبالاعتبار ( يعرف من أين صار الحسن حسنا ، والقبيح قبيحا ) ( ') . }
$$

القسم الثاني : أهل العناية المبعدون عن فهم التجربة ، وهؤلاء تأتيهم المعرفة على

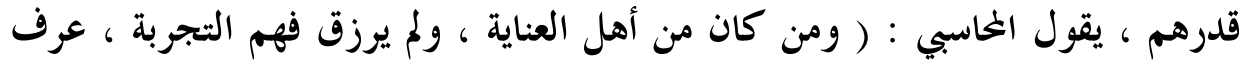

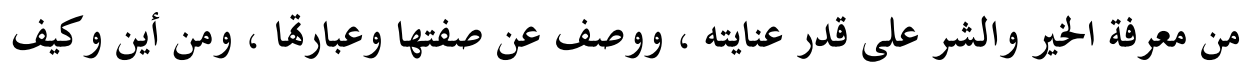

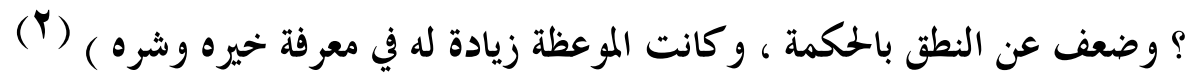
ويلاحظ في تقسيم الإمام الخاسبي أنه مقارنة بين منهجين ، أحدهما رزق فهم التجربة دون غيره ، لكن جذب انتباهي عبارتان : الأولى " بلغ معرفة الحير والشر " وهي فيمن رزق فهم التجربة ، وكان من أهل

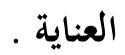
والثانية : " كانت الموعظة زيادة له في معرفة خيره وشره " وهي فيمن لم يرزق

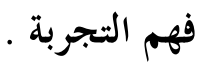
وأعتقد أن الإمام الخاسبي من خلال كلماته تلك يؤكد على حقيقة وأهمية المنهج

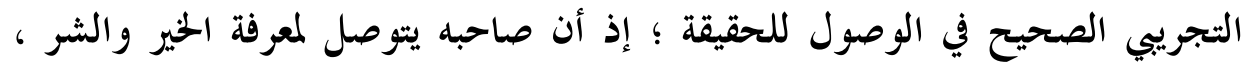

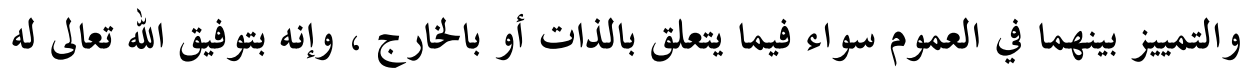

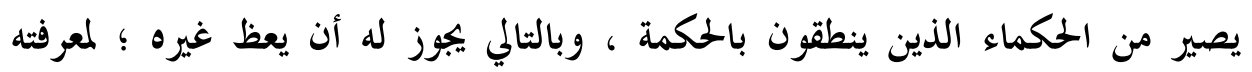

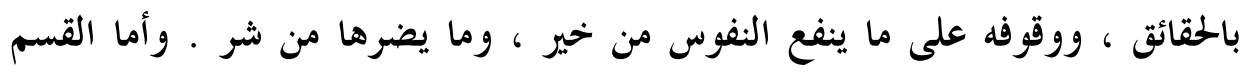

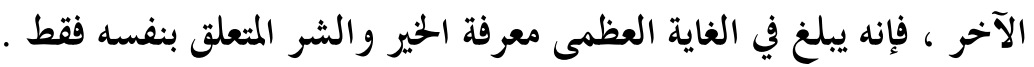

$$
\text { نفسه ص •r }
$$




\section{منهـج الإمسام المحاسـبي في الوصسول لليقسين}

القسم الثالث : المبعدون عن فهم التجربة غير المعتنين بأنفسهم ، والفرد في هذا القسم ( لم يرزق فهم التجربة ، وليست له عناية بنفسه ، فهو لا ينطق بلسانه عند المعند

$$
\text { الكلام ، ولا يعقل بقلبه عند السماع ) (1 ) تطبيق قاعدة فهم التجربة }
$$

وتطبيقا لهذه القاعدة المنهجية التي أصل لها الخاسبي ، يتكلم عن كيفية الوصول

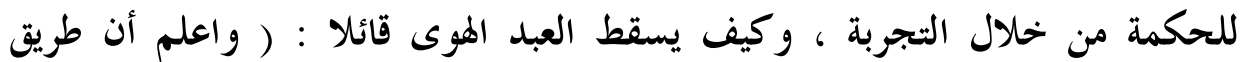
الحكمة هو الصمت، فإذا صمت ملكت قلبك، فيكون صمتك فكرا، ونظرك اعتبارا ،

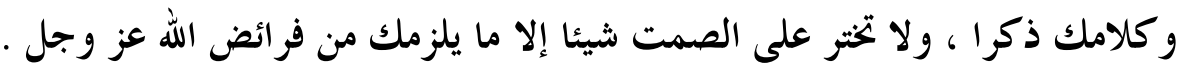
وهذه خصال مجربة ، جربها أهل الخاسبة لأنفسهم ، فلما قاموا بها أحكموها بإذن

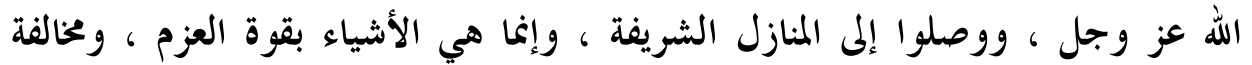

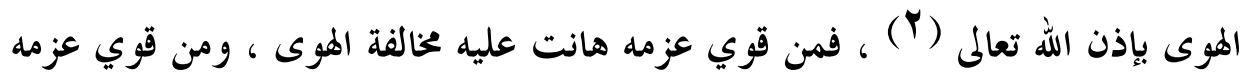
يتبين له فضله في قلبه ، ويتبين له الذي يأتيه من عون الله تعالى له ) ("َ). فالفهم للتجارب عند الخاسبي يقوم على أمرين : أولمما : شخصي ذاتي به ينطلق العبد من تجارب نفسية وقتية ، ينظر في فعاله ، ويقيسها بنفسه على الوقت الذي يحيا فيه ، والأشخاص الذين يعاينهم ويعاصرهم ،

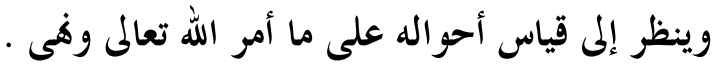

$$
\text { نفسه . }
$$

دائما ما يؤكد الخاسبي على هذين الأمرين في السير لليقين ، وهما مخالفة الهوى وما يتعلق به ، والثاني

أن العبد في طريق سيره إلى اليقين مدفوع بالبدء من نفسه لكنه لا يصل إلا بتوفيق الله تعلى له .

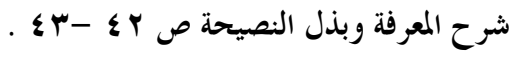




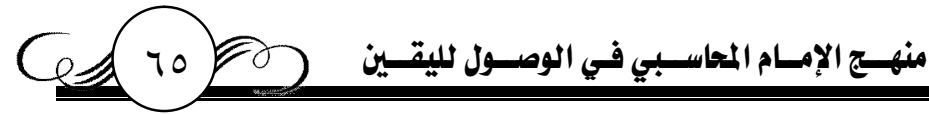

ثانيها : عام يقوم على النظر في التجارب السابقة وفهمها ، وعلى النظر في المعارف السابقة ، والعارفون قبله بحيث يبني معارفه على معرفتهم ، ويقيس حاله على أحو الهم في العلم والعمل معا ، دون تقصير في النظر أو الفهم .

\section{المقاس عليهم}

عند القياس ، وفهم التجارب مع الاستقراء ، وبعد إسقاط الهوى وتصحيح النظر

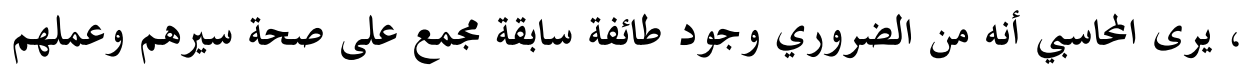

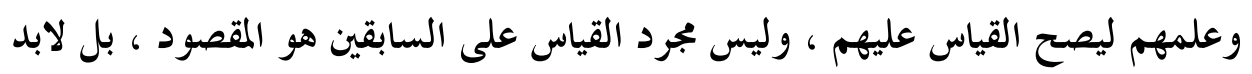
من أن يكون موجها لطائفة لم يختلف الجميع عليهم حتى يكون الاستقراء صحيحا ، والقياس منتجا لليقين ، وليس مجرد عملية عقلية فقط .

وهذه الطائفة عند الخاسبي هم الصحابة رضوان الله عليهم ، فهم أفضل العارفين

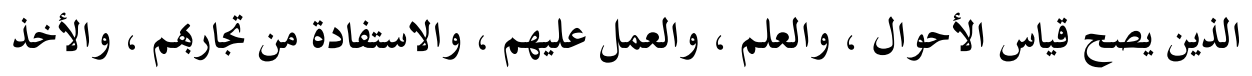

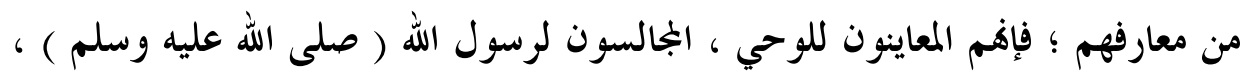

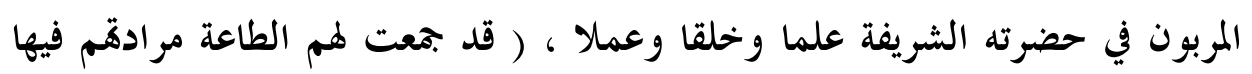
على قدر الإقبال عليها ، وأوضحت لهم سبل الرشاد فيها ، فلم يريدوا بما أدركت يد الظفر منهم بدلا ، ولم يبغوا عن شيء من ذلك حولا ، وأصبحوا في ذلك توفيقا من سيدهم ، ومعونة قائمة بالكفاية لهم ، وخفي لطف غير منقطع عنهم ، فدام لهم الحال وزكت الأعمال ، ووجدوا الظفر بالآمال ، ولم يجدوا عند ذلك هوى غالبا ، ولا عدوا مطالبا ، ولا أملا في النفوس كاذبا ) (1) . . ومرجع ذلك كله فيهم إلى أنه قد ( أمات العلم بالله أهواءهم ، وغلب لهم أعداءهم ، و.جع لهم شملهم ، وأحكم لهم أمرهم ، و كان

الحارث الخاسبي : المكاسب ص به ـ تحقيق : عبدالقادر أحمد عطا ـ مؤسسة الكتب الثقافية ـ بيروت

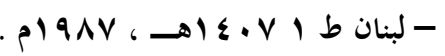




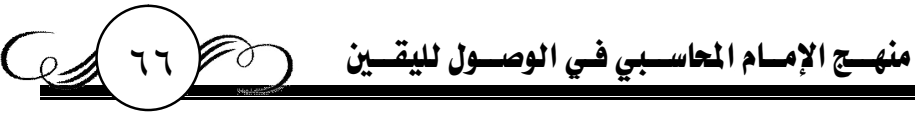

التوفيق لهم صاحبا ، وخفي اللطف من الله دائما ، و التأييد لهم من سيدهم مرشدا ) (1 )

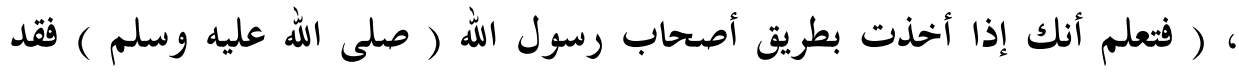
أفلحت و أفلحت حجتك ، وتنال بغيتك ، ولا تخالفهم في شيء من الأشياء ، فإنمم كانوا

على الحق المبين ، والنور الواضح ، فاتبع سبيلهم ، ولا تخالفهم فيخالف بك ) (ب).

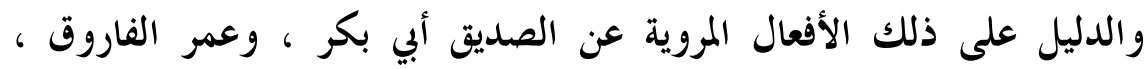
وعثمان ذي النورين ، وعلي بن أبي طالب، وأكثر أصحاب البي ( صلى الله عليه وسلم ) من المختارين لصحبته المنتخبين لمعونته ، وقد مدح الله تعالم أصحاب رسوله ( صلى الله عليه وسلم ) في مواضع كثيرة من كتابه ، وهم أفضل أهل الأرض بعد الأنبياء ( عليهم

السلام ) ، وأعمالهم أفضل الأعمال وأشرفها ، ومقاماتم أرفع المقامات وأعلاها (بّ). وتطبيق لهذه القاعدة المنهجية عند الحارث الخحاسبي فإنه قد أعلن أن السلف ألف ألف

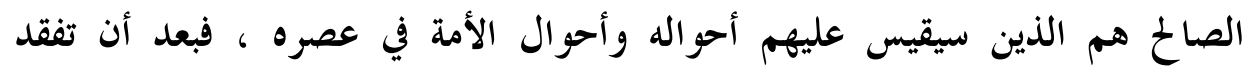
الأصناف ووجد غلبة الهوى ، وتبدل الشرائع ، أعلن أنه أصدر هذا الحكم عن قياس وتجربة ، واستقراء للمعارف السابقة ، وهو أن ( الضمائر والأحوال في دهره بخلاف أحوال السلف وضمائرهم ، ولقد بلغه أن بعض الصحابة قال : لو أن رجلا من السلف ولف وله الصالح أنشر من قبره ثم نظر إلى قرائكم ما كلمهر ، ولقال لسائر الناس : ما يؤمن

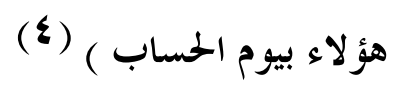

ومثال آخر يضربه الخاسبي للمقارنة بين عصره وعصر الصحابة ، فتكلم عن

$$
\begin{aligned}
& \text { نفسه . } \\
& \text { شرح المعرفة ص ه ه ه . } \\
& \text { المكاسب . ص OV-OV بتصرف . } \\
& \text { الوصايا - النصائح - ص צا } 7 \text { بتصرف يسير . }
\end{aligned}
$$




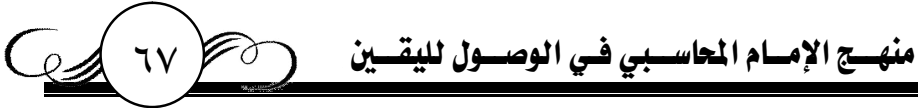

حال الصحابة في جع المال ، ورضاهم بالكفاف ، وأن ذهاب الدنيا أفضل من إقبالها ، وأن الناس في عصره كانوا عكس ذلك تماما من إقبال على الدنيا ، وعدم التفكر

بالآخرة (1)

\section{المرحلة الرابعة : إعلان نتائج البحث}

عقب انتهاء البحث ، وخوض التجارب ، و واستدامة المراجعة ، يعلن الإمام الخاسبي عن النتائج التي توصل إليها في بحثه عن اليقين من خلال المراحل السابقة . ففي بداية بكثه أعلن عن سبيل النجاة الجمعع عليه ، وهو تقوى الله تعلى ، وأن طريق تحصيله هو الاتباع ، وأن هذه هي المعرفة اليقينية التي سيسعى لتحقيقها ، ثت أعلن أنه قام بالتجارب والاستقراء لكل الأفكار بعد إسقاطه للهوى ، وتجريده للعقل كآلة

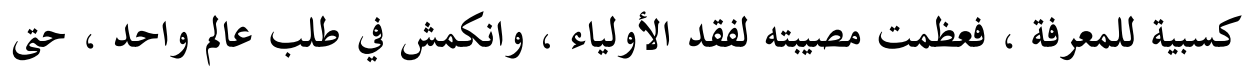
قيض له الرؤف سبحانه وتعالى قوما وجد فيهم دلائل التقوى(Y) ، ووجد إرشادهم

انظر : الوصايا - النصائح - ص •^-1 1ـ. ويعتبر كتاب المكاسب للمحاسبي تطبيقا كاملا لمنهجه في

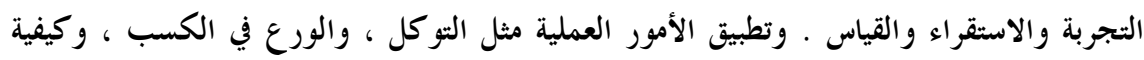

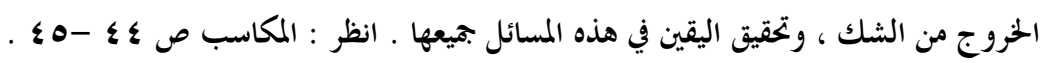

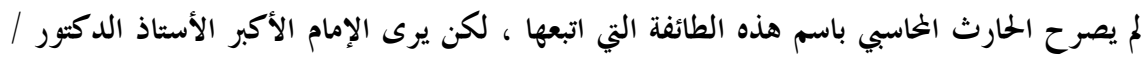

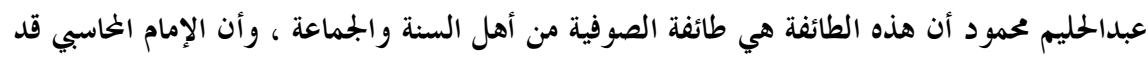

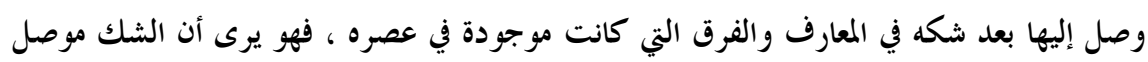

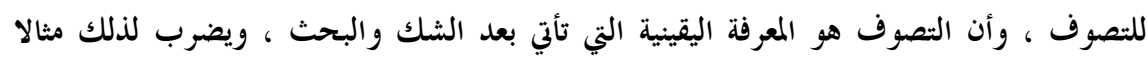

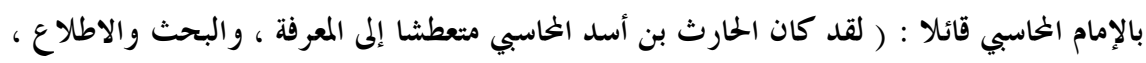

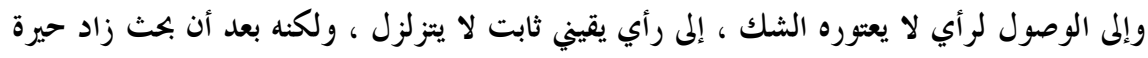

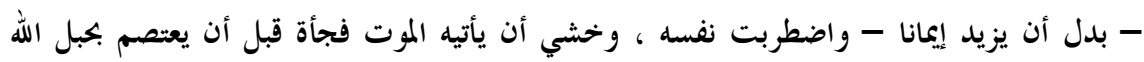

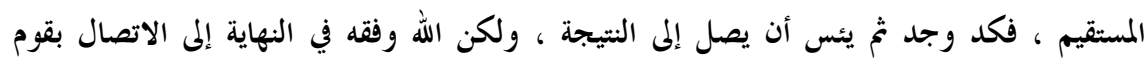

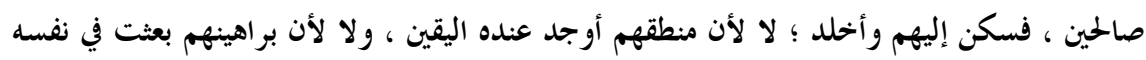
$=$ 


\section{منهــج الإمـام المحاسـبي في الوصسول لليقـين}

مو افقا لأفاعيل أئمة المدى من الصحابة ، مؤتمرين بالأوامر ، منتهين عما فىى الله عنه ، مخالفين لأهوائهم ، محاسبين لأنفسهم ، مالكين لجحوارحهم ، مجانبين للشبهات ، تاركين للشهوات ، لكل امرئ منهم شأن يغنيه ، علماء بأمر الآخرة ( (1). وعندئذ تبين للإمام الخاسبي فضلهم ، و اتضح له نصحهم ، وأيقن أنم العاملون

بأمر الآخرة ، و المتأسون بالمرسلين ، و المصابيح لمن استضاء بكم (广). ثم يعلن نتيجته الذاتية التي توصل إليها ، وهي أن النجاة في اتباع هؤلاء القوم ، وأن الاعوجاج لمن خالفهم ، فيقول : ( فأصبحت راغبا في مذهبهم مقتبسا من فوائدهم

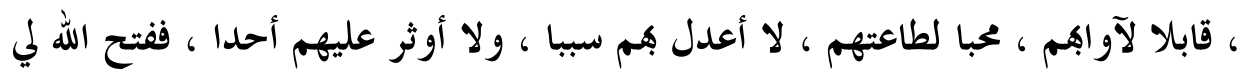
علما اتضح لي برهانه ، وأنار لي فضله ، ورجوت النجاة لمن اقتربه و انتحله (ب) ، وأيقنت بالغوث لمن عمل به .

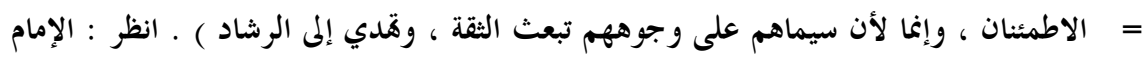

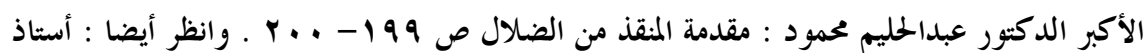

$$
\begin{aligned}
& \text { السائرين ص } 19 .
\end{aligned}
$$

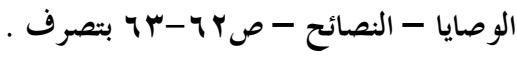

$$
\begin{aligned}
& \text { الوصايا - النصائح - ص ץ צ-r 7 بتصرف . }
\end{aligned}
$$

على الرغم من ان الإمام الخاسبي وصل إلى هذه النتيجة من مقدمات صحيحة ، بعد نظر وإسقاط

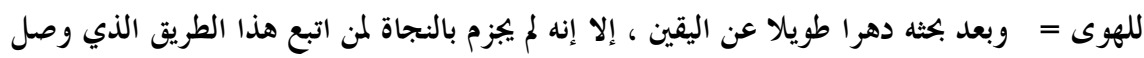

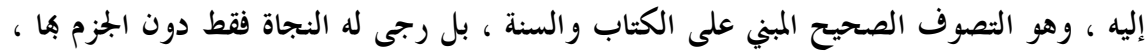

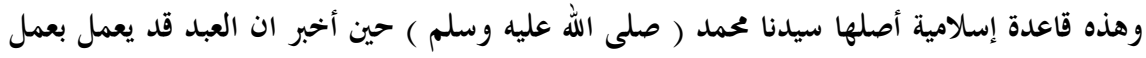

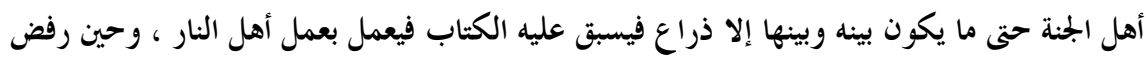

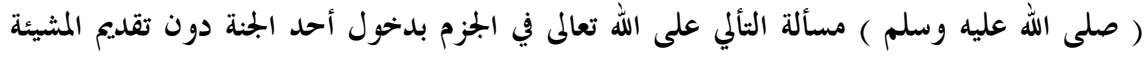




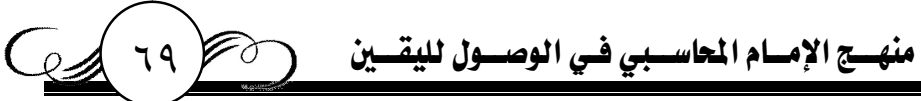

ورأيت الاعوجاج فيمن خالفه ، ورايت الرين متراكما على قلب من جهله

وجحده ، ورأيت الحجة العظمى لمن فهمه ، ورأيت انتحاله والعمل بحدوده واجبا علي ، فاعتقدته في سريرتي ، وانطويت عليه بضميري ، وجعلته أساس ديني ، وبنيت عليه

$$
\text { أعمالي ، وتقلبت فيه أحوالي ) (1) }
$$

ويؤكد الخاسبي - كما تقدم في غير مرة - أن ذلك كله بفضل الله تعالم عليه ، وأن هذا نعمة تستحق الشكر قائلا : ( وسألت الله عز وجل أن يوزعني شكر ما أنعم علي ، وأن يقويني على القيام بحدود ما عرفني به ، مع معرفتي بتقصيري في ذلك ن وأني لا أدرك شكره أبدا ) (Y) فالنيجة عند الخاسبي ذات شقين : الأول منها ذالي ، والثاني خارجي . ففي الأول يجب على الباحث أن يتأكد من وصوله لليقين أولا مع التثبت ودوام المراجعة ، وفي الثاني : يجب عليه التعريف بتجربته التي خاضها ، والمسائل التي وقفت أمامه ، والعقبات التي عاقته في مرحلة ما عن الوصول للحقيقة ؛ حتى يحذر منها من يأت بعده مطبقا لتجربته ، وهذه النتائج عند الخحاسبي هي : أولا : ضرورة العمل بالأمور الصالحة جميعها ، وقد ذكرها الخاسبي منثورة في كتابه الوصايا ، وفي كتابيه الرائعين : آداب النفوس ، والرعاية لحقوق الله ، ويعتبر كتابه المكاسب تطبيت لكامل منهجه في هذه المسألة . ثم إذا لم يستطع الانسان القيام بهذه الأمور جميعها ، فإن عليه أن يتمسك بما تتحقق به النجاة يقينا، وهو الفرائض ، وهذا أقل ما يمكن التمسك به في باب النجاة ،

$$
\begin{aligned}
& \text { الوصايا - النصائح -ص ب ז-צ } 7 \\
& \text { نفسه ص \& } 7 .
\end{aligned}
$$




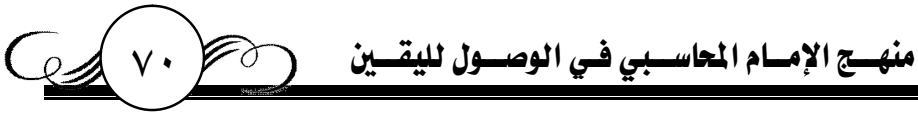

يقول الخاسبي : ( إخواني : إن فنون العلم والعبادة ، وجميع ما يتقرب به إلى الله تعالم

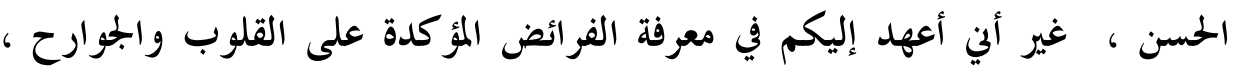
ومعرفة الورع في المكاسب ، وفي الأحوال الظاهرة والباطنة ، والعمل بحسن النية ،

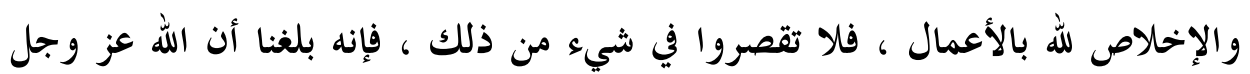
يقول : لا ينجوا مني عبد إلا بأداء ما افترضت عليه ، ألا فانكمشوا في الفرائض التي

يسخط الله من يضيعها ، ويفوز العباد بأدائها ) (1)

ثانيا : التأسي بالصادقين وسلوك طريقهم ، وهم : ( الفاهمون عن الله تعالم الموفقون بتوفيقه ، الذين استخلصهم من خلقه ، فانقطعوا عن العباد إلى الله تعالى بممومهم ، ولم يكن فيهم فضل لغيره ، ولا تزين لسواه ، تدبروا العواقب وطلبوا معالي

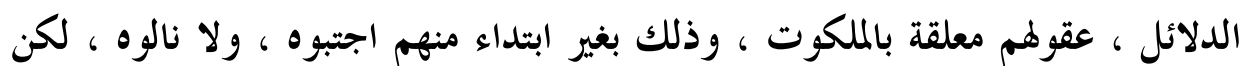

بتفضل الله عز وجل عليهم ، وتعبده إياهم ) (†).

فهؤلاء يراهم الخحاسبي أهلا للاتباع ، ويسأل الله تعالى أن يكون منهم ، ويحض غيره على ذلك قائلا : ( فأقامنا الله وإياك مقامهم ، وأسلكنا وإياك سبيلهم ، حتى يلحقنا

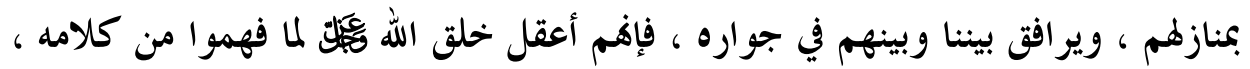
وتدبروا معاني قوله ، وبذلك أمنهم ، ورضي عنهم وأثنى عليهم ورفع قدرهم ) (ب)

$$
\begin{aligned}
& \text { نفسه ص 110. وانظر : آداب النفوس ص • با . }
\end{aligned}
$$

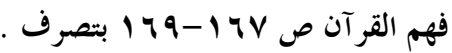

فهم القرآن ص 9 ج ـ ـ وهذه الطائفة هي طائفة الخققين من الصوفية كما أشار إلى ذلك الإمام

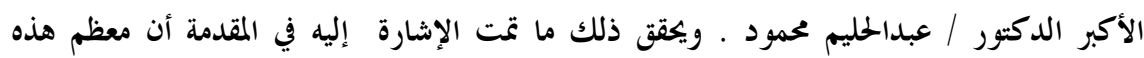

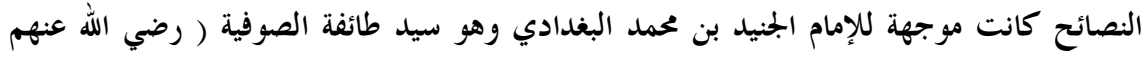




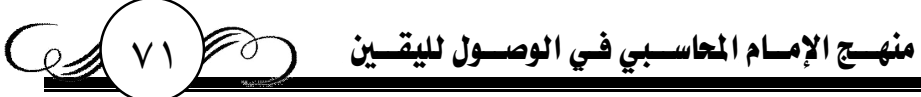

ثالثا : التحذير من النظر في الاختلاف : وقد أطنب الخاسبي في عرض هذه النتيجة حيث إفا تمثل نتاج تجربته ، ونتاج استقر ائه التام للأفكار ، والأشخاص ، ويريد نقل تجربته في هذه المسألة على نحو تام ، فيقول : ( وبعد : فأحذركم النظر والبحث في اختلاف الأمة ( (1). وقد انتهى إليكم الذي حل بهم من أجل الاختلاف ، والنظر في أهل الفرق وما ابتلوا به من الأهواء المضلة ، وارتكاب العظائم من مذاهب القدرية ،

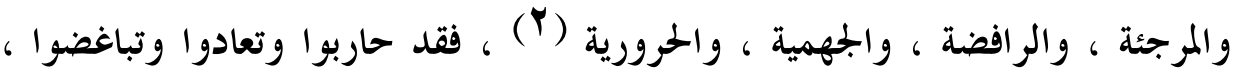
وشهد بعضهم على بعض بالكفر و الضلال ، واستحلوا دماء المخالفين لأهوائهم ، وقد كانوا من قبل ذلك إخوانا على أمر الله متفقين ، فلما بلوا بالبحث والتعمق صاروا أصنافا ، واحتج كل قوم بمتشابه القرآن ، وبالآثار التي توافق أهو اءهم فضلوا وأضلوا

بذلك كثير ) (َ) (

قد يقال : إن الخاسبي قد وقع فيما حذر منه ، ودعا إلى اجتناب ما وقع فيه ! ، أقول وبالله الثوفيق :

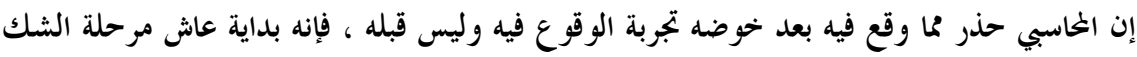

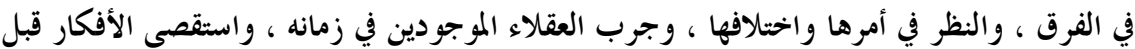
زمنه ، وفهم التجارب ، وأرشده الله تعالى لطريق الصادقين ، فاتبعم ، وفهم حقيقة النجاة في العبادة

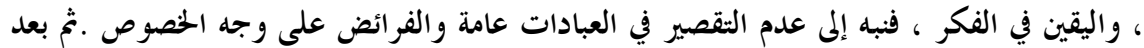

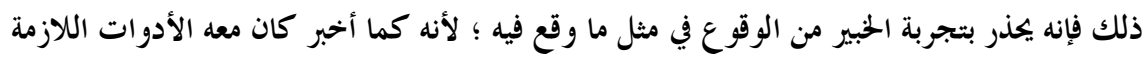

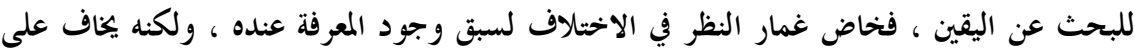

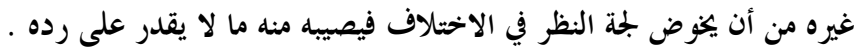

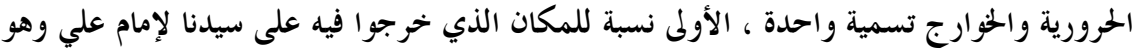
حروراء ـ والثانية نسبة لفعلهم وهو الحروج على الإمام ـ انظر في التعريف بالحوارج وفرقهم : أبو

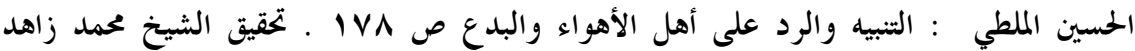

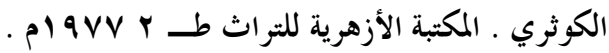

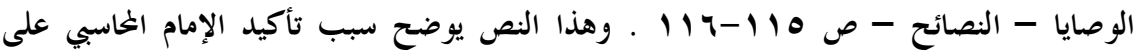
ضرورة إسقاط الهوى عند البحث، وتجريد العقل المفكر في النصوص ، وتصحيح النظر في الاختلاف . 


\section{منهــ الإمسام المحاسـبي في الوصسول لليقـين}

ثم يكرر الخاسبي الطلب بالمراقبة ، وترك البحث في الاختلاف ، والتعمق به مع التع

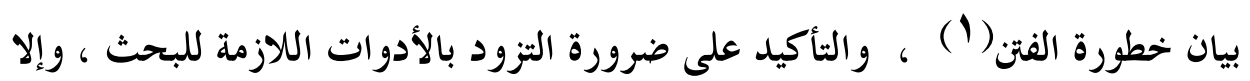

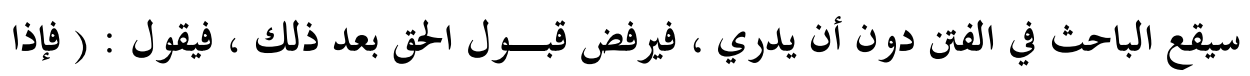

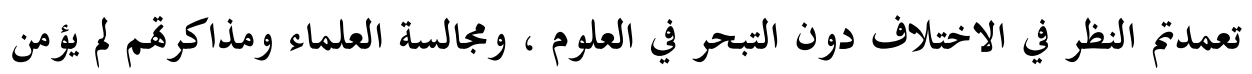
عليكم أن تبتلوا بشيء يســق إلى قلوبكم من الفتنة ، ويقال : ما من ضلالة إلا وعليها

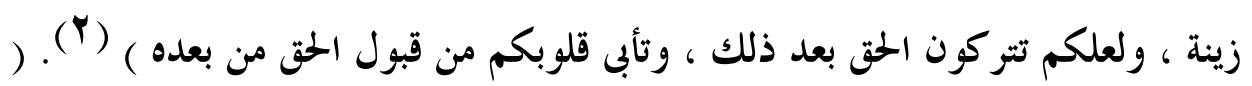

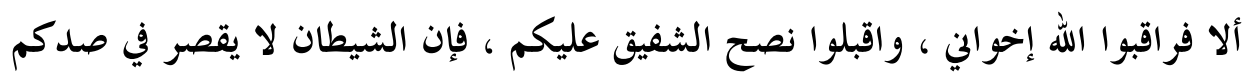

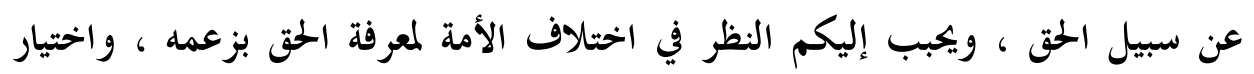

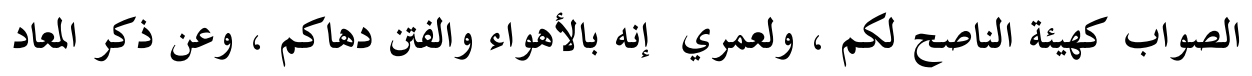

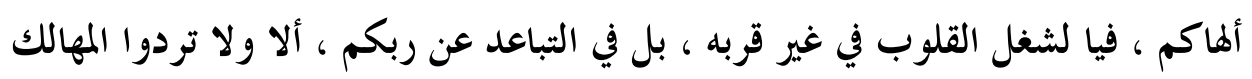
باتباع الهوى عصمنا الله وإياكم من ذلك آمين ) ("َ) . وفي فايات كتابه النصائح يقول

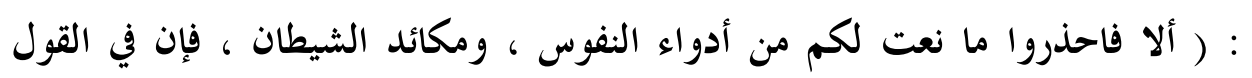

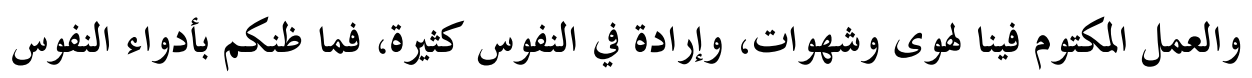

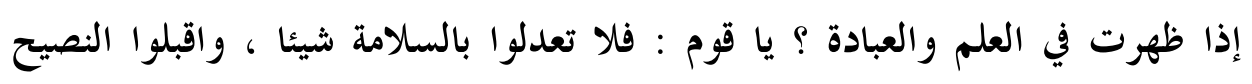

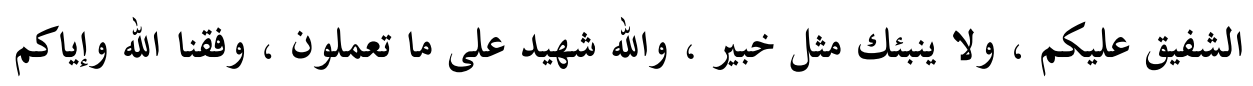

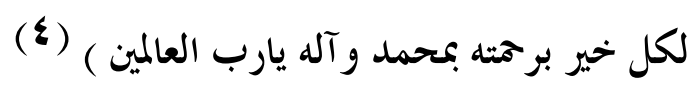

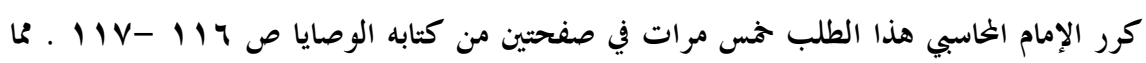

يدل على أهمية المراقبة ودوام المراجعة في تثبيت المعرفة اليقينية .

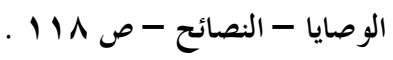

$$
\begin{aligned}
& \text { نفسه ص } 119 . \\
& \text { الوصايا - النصائح - ص • ب . . . }
\end{aligned}
$$


منهـج الإمسام المحاسبي في الوصسول لليقسين

\section{المرحلة الحخامسة : دوام المراجعة}

بعد انتهاء مرحلة الشك القائم على النظر الجرد ، وتصحيح آلة المعرفة لتحقيق

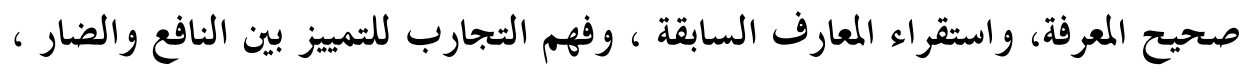

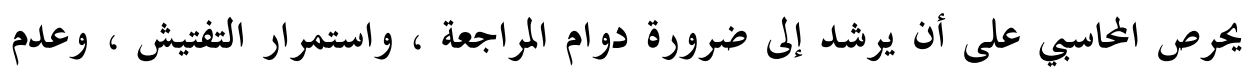

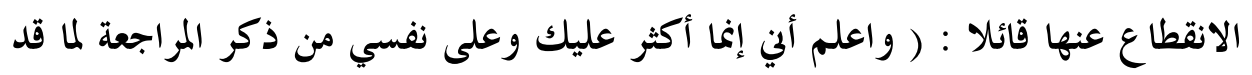

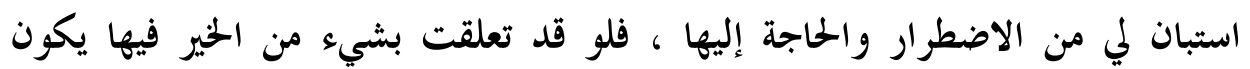

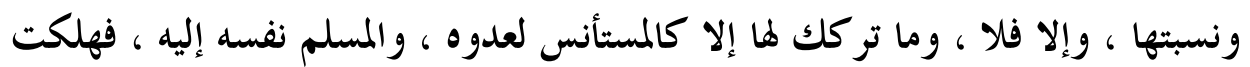

$$
\text { وأنت لا تشعر ) (1) }
$$

وللمر اجعة متزلة عظيمة في الوصول لليقين في المعرفة ، وتثبيته ، فبها يكون العبد

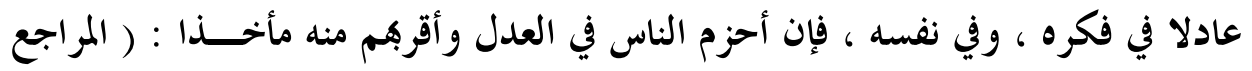

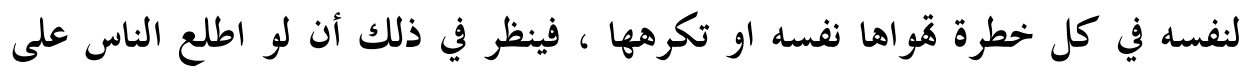

حالثه هذه ، فاستحيا أو كرهها تحول من تلك الحالة إلى حالة لا يستحيا منها ) (r).

$$
\text { المر اجعة سبيل النجاة }
$$

تمثل المراجعة المستمرة في نظر الخاسبي سبيلا للسلامة وتحقيق النجاة ؛ فإن العبد

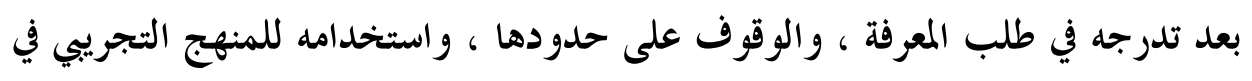

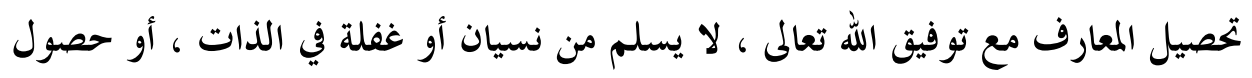

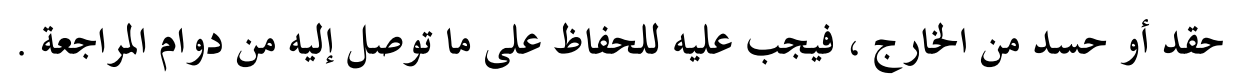
وقد تحقق الخحابي من ذلك بالتجربة قائلا : (واعلم أنك مسبوق إلى ضميرك

$$
\begin{aligned}
& \text { آداب النفوس ص זr. } \\
& \text { نفسه ص \ } 2 .
\end{aligned}
$$




\section{منهـج الإمسام المحاسببي في الوصسول لليقسين}

بالحسد وسوء الظن والحقد ، فاجعل المراجعة شغلا لازما ، وكن وقافا كما قال الأول : المؤمن وقاف وليس كحاطب ليل ، فقف وطالع زوايا ضميرك بعين حديدة النظر نافذة

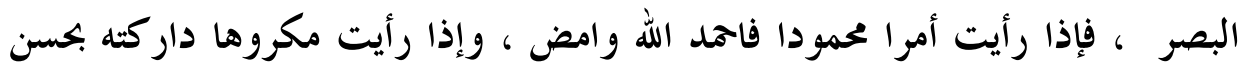
المراجعة واستقصيت فيه (1) ، فإن الذي دخل بيتك ولم يستأذنك سوف يختبئ فيه ، وإن كان مظلما فأنت لا تشعر إلا أن يكون معك سراج من العلم مضيء واضح ،

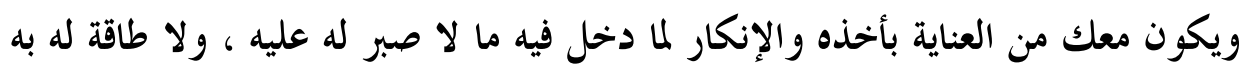

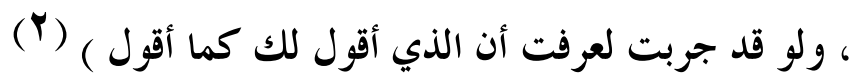
ويقول : (فاعتن بتعاهد هذه المراجعة على قدر ما عرفت من حاجتك إليها ، فإنما لك من عمرك تيقظك ، وتيقظك مر اجعة ما فيه منفعتك وقربتك ، و المصير إليه بالعقل ، وما سوى ذلك غفلة وسهو يؤديان إلى شهوة فيها غليان قلبك ، وفي ذلك موافقة فئة نفسك الأمارة بالسوء، والهوى المضل عن سبيل الله العادل بأهله عن طريق محبته ) ("َّ). ويستمر الخاسبي في تأكيده على أن السير إلى الحقيقة ، وتحقيقها ، وإدراك صحيح

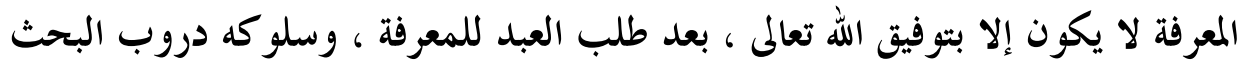
عن اليقين ، فيقول : ( وإذا رأيت لك عناية بالمراجعة ، فاعلم أفا نعمة وقربة من العابل أعظم

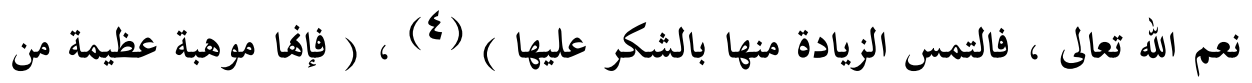

أي استقرأته استقراءا تاما لتقف على حقيقة ما أنت فيه ، وما هو أولى ان تكون فيه . آداب النفوس ص اله. والخاسبي يؤكد مرة أخرى على أن التجربة هي خير وسيلة للوصول لليقين ، وأن فهمها هو المثبت لليقين في العقل والقلب ، وأن دوام المراجعة هو سبيل الحفاظ على النتائج التي

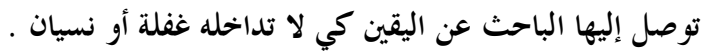

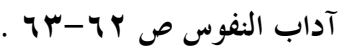

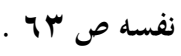




\section{منهـج الإمسام المحاسببي في الوصسول لليقسين}

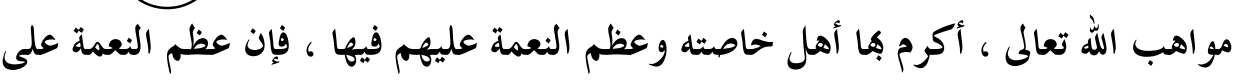

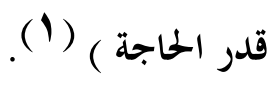

\section{تطبيق المنهج في دوام المراجعة}

تظهر الصورة الجلية لمنهج الخاسبي في الوصول لليقين ، في تطبيقه لقاعدة دوام

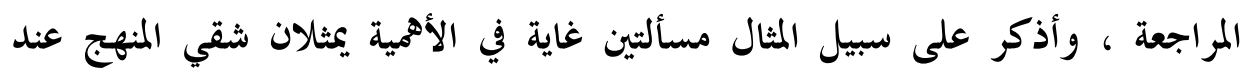

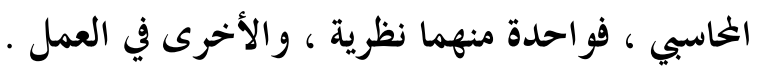

الأولى : المتعلقة بالعمل وهي الصلاة حيث يرى الخحاسبي ضرورة المراجعة فيها

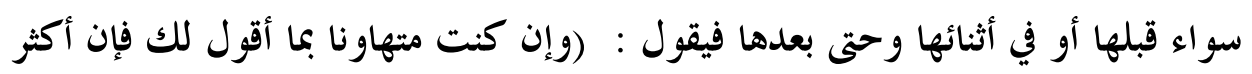

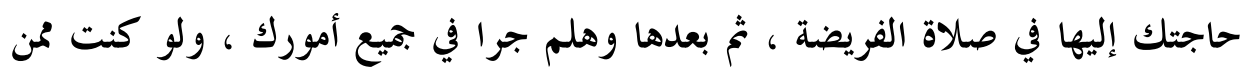

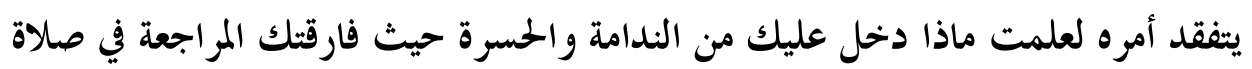

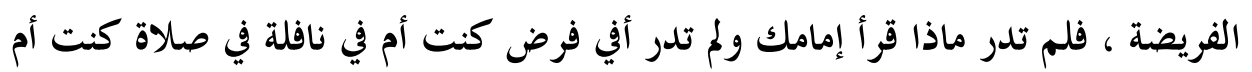

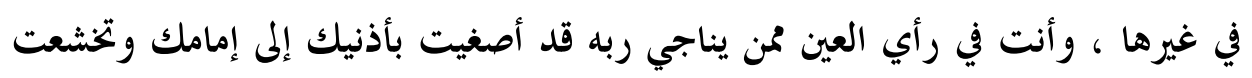

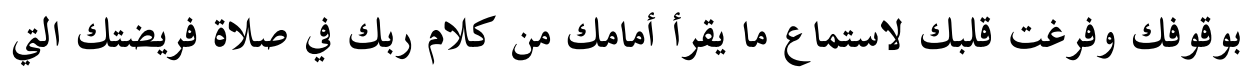

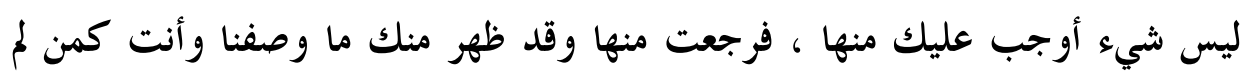

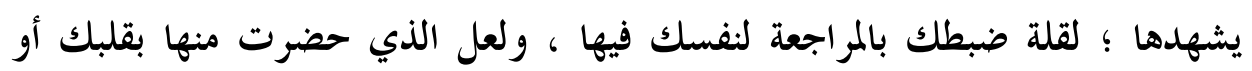

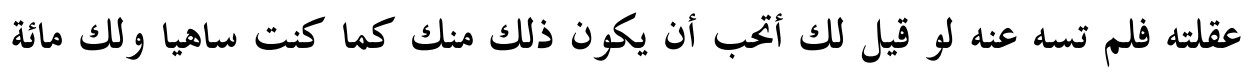

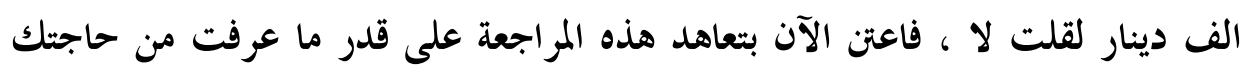

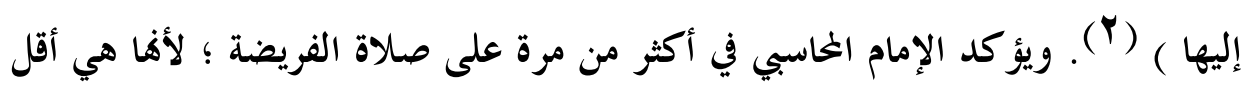

$$
\text { نفسه ص ץ YY . }
$$




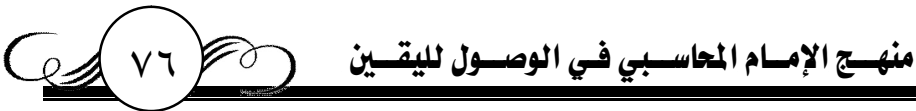

ما يوصل العبد للنجاة (1).

الثانية : دوام المراجعة في نتائج النظر حتى اليقين ، ثم استمرار المراجعة للمتبعين :

فبعد أن وصل الخحاسبي لليقين في الفكر ، وأخبر ان الله تعالمى قد وفقه لقوم مهتدين ، لم يقف عند هذا الحد بل إنه أخذ ينظر في تطبيق هؤلاء للأفكار التي اتبعوها ، مستخدما منهجه الذي اعتمده سابقا ، وهو قياس الأفراد على الكتاب والسنة وعمل الصحابة . فنظر في أفكار بعض الصوفية ، وقاس أفكارهم وآراءهم على الكتاب والسنة وعمل الصحابة ، فتبين له مخالفة بعضهم في اجتهاداتم للمحكم من القرآن والسنة وعمل الصحابة ، و من أمثلة ذلك : نقد قولهم بترك الحركة في الكسب : يقول الخحاسبي : ( وقد ترك الحر كة في الكسب أقوام (Y) ، على أمور مختلفة ، وأنا واصف بعضها إن شاء الله تعالم ، فمن ذلك ما زعم شقيق ( البلني ع 9 اهــ ) فيما يروى عنه أنه كان يقول : إن الحركة في الكسب معصية ، وذلك انه قال : لما ضمن الله تعالى الرزق لهاء والكفاية ، كانت الحر كة شكا فيما ضمن فحمل الأمر في ذلك على رأيه ، وقال فيه بزلل ، فخالف الكتاب والسنة ، وما عليه أكابر أصحاب رسول الله ( صلى الله عليه وسلم ) ، وجلة التابعين من بعدهم . (َّ) ثم استدل الإمام الخاسبي على ما ذهب إليه بآيات من القر آن ونصوص من السنة توضح صدق نقده ، فمن القر آن الكريم قوله تعالم إلى

$$
\text { النصائح ص } 110 .
$$

تجدر الإشارة إلى أن الحارث الخاسبي قد تكلم في مسألة الكسب موضحا الواجب فيها من الكتاب

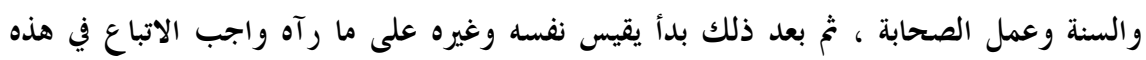

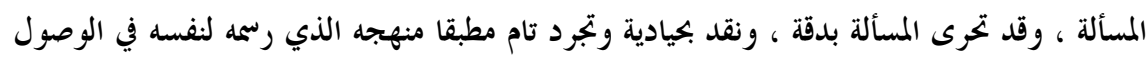

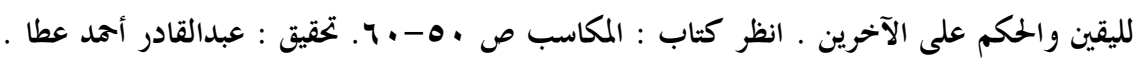




\section{منهـج الإمسام المحاسببي في الوصسول لليقسين}

:

قوله ( صلى الله عليه وسلم ) : ( أفضل ما أكل الرجل من كسبه ) (1) وفي هذا آيات كثيرة من كناب الله تعلى ، وأخبار عن رسول الله ( صلى الله عليه وسلم ) متواترة ،

وفي أقل مما ذكر يتبين خطأ هذه المقالة (r).

\section{المرحلة السادسة : العمل على اليقين وترك الشك :}

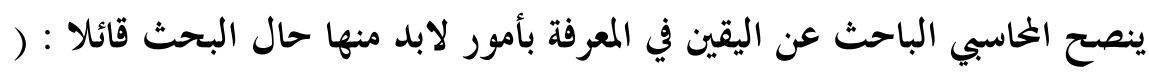

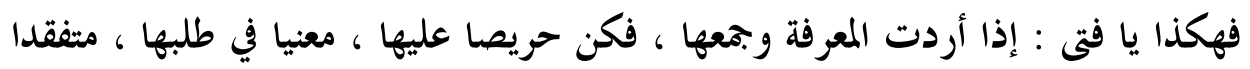

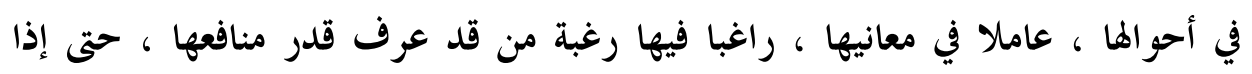

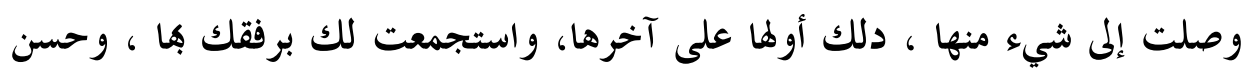

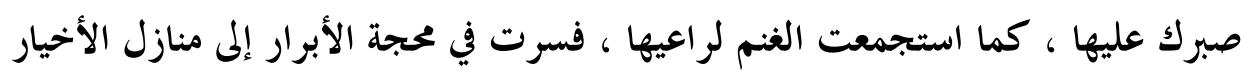

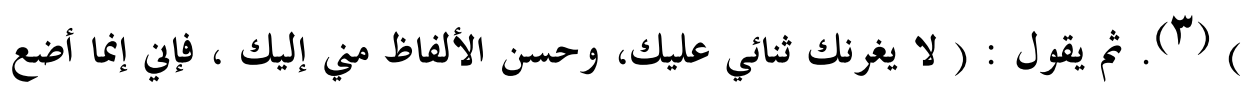

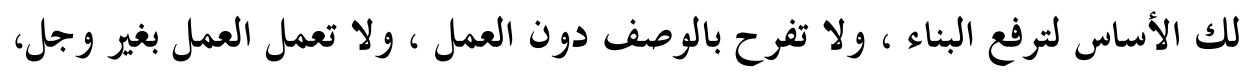

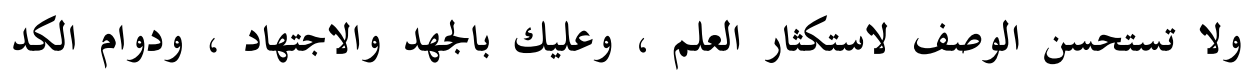

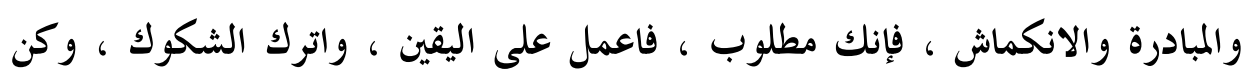

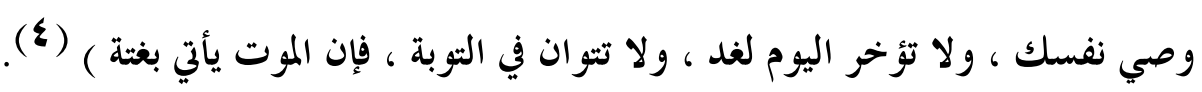

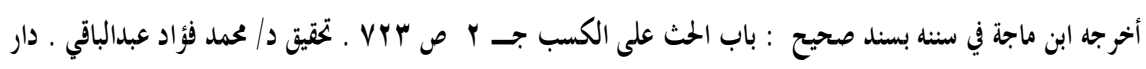

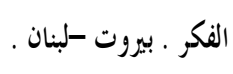

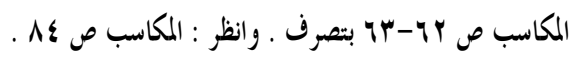

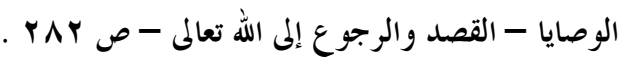

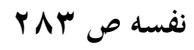


منهـج الإمسام المحاسبي في الوصسول لليقسين

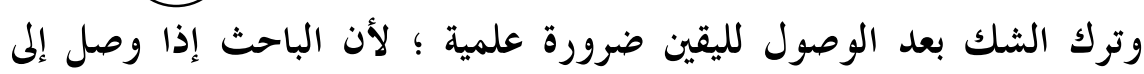

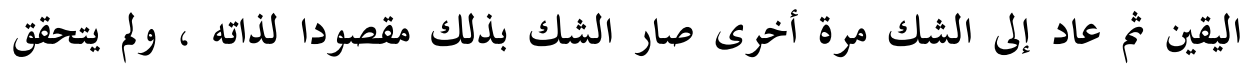

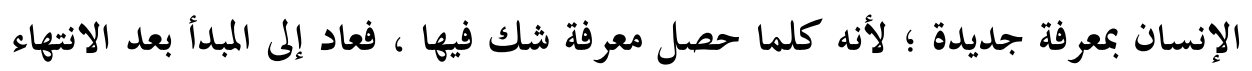

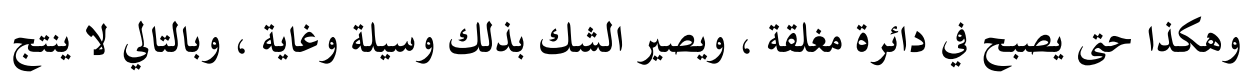

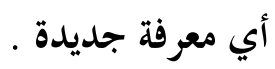

وهذه القاعدة وضعها الخاسبي بعد ذكره لأمور مهمة تعوض عن الشك في أثناء

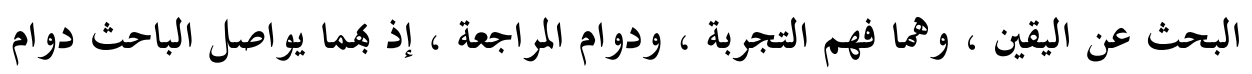

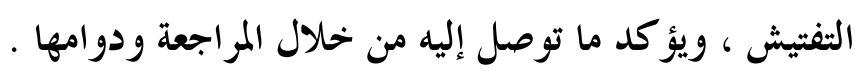




\section{منهـج الإمسام المحاسـبي في الوصسول لليقسين | آنّم:

$$
\text { وتشتمل على أهم نتائج البحث }
$$

يعتبر الحارث الخاسبي من أوائل الباحثين عن اليقين من خلال المنهج التجريبي في الفكر الإسلامي وغيره ، وقد سبق بطريقته هذه كل الأفكار التي قدمت في هذا الميدان ، فالخاسبي هو أستاذ الباحثين عن اليقين ؛ فهو الذي وضع النواة الأولية لهذا المنهج ،

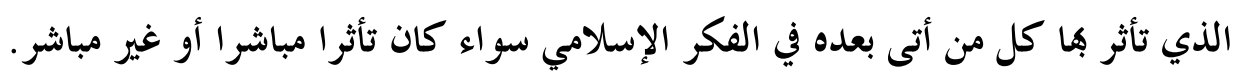
فالغاسبي رائد المنهج التجريبي ، ورائد الوصول لليقين من خلال الشك كمرحلة أولى ، فله السبق على غيره من الكثير من الفلاسفة الذين ينسب إليهم هذا الأمر كالإمام الغزالي ، وبيكون ، وديكارت ، وغيرهم ، فهؤلاء بميعا ساروا على نفس المنهج

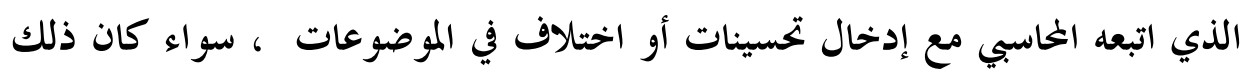

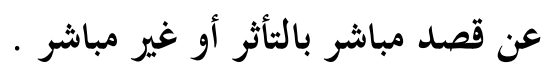

وقد انتهج الخحاسبي منهجا خاصا به في الوصول لليقين ، وتوصل لنتائج مهمة في عمليات البحث العلمي والديني ، حيث لم يفصل الخحاسبي في منهجه بين النظر العقلي

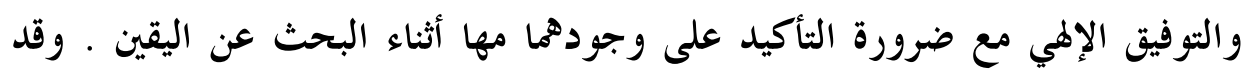
وضع الإمام الخاسبي القواعد العامة لمنهجه في كتابه الوصايا ( النصائح ) ، ثم فصل كثيرا من هذه القواعد في نفس الكتاب ، وفي كتابه ( آداب النفوس ) ، و كانت بقية الكتب شارحة ومطبقة لهذا المنهج ، فمثلا : كتابه ( فهم القرآن ) يعتبر تطبيقا عمليا لقاعدة تصحيح النظر بالعقل ، حيث طبق فيه الخاسبي قاعدة تجريد آلة المعرفة ، وقسم العقلاء عن الله تعالمى ، وكيفية الوصول لليقين في فهم كتاب الله تعالى . و كتابه المكاسب يعتبر تطبيقا لكامل منهجه على مسائل الحلال والحرام والورع ، و النجاة في الآخرة التي كان يسعى إليها .

وقد تمثلت خطوات المنهج وأهم النتائج التي توصل إليها الخاسبي في الآتي : 


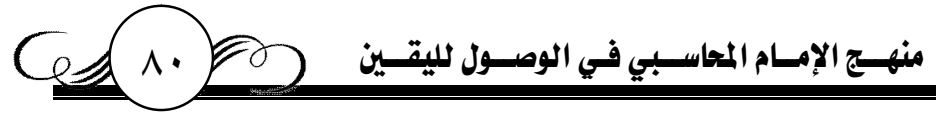

1- الشك أول درجات المعرفة ، والعاقل هو من يعمل على التخلص منه بأدوات

عقلية مناسبة، حتى يدركه لطف الله تعالى ليتخلص من الشكوك جملة وتفصيلا . ץ- تحديد الغاية من النظر والفكر سابق على عملية الفكر والنظر ، حتى يتسنى

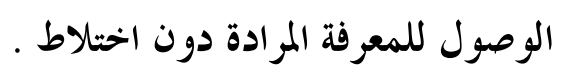

r- النظر الصحيح في بدايته لابد أن يكون كليا جامعا للأفكار ومعتنقيها ، وليس

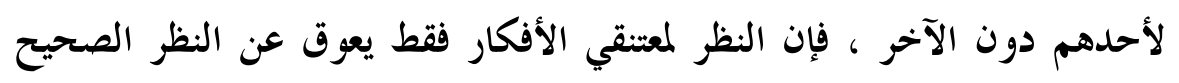

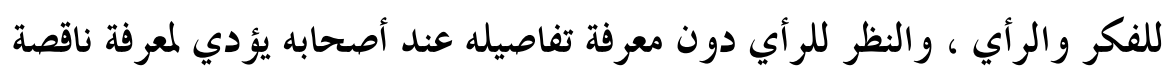

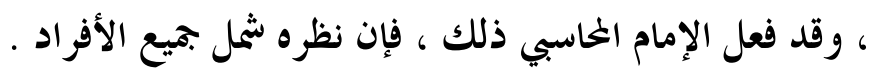

ع - قياس الباحث لنفسه على الآراء الموجودة أمر ضروري حتى يعرف موقعه في الفكر ، ودرجته في البحث عن اليقين .

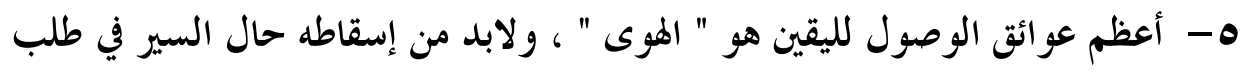

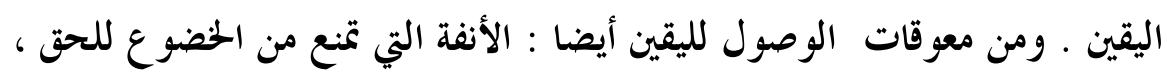

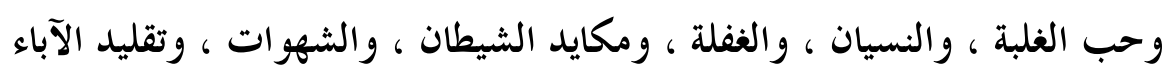

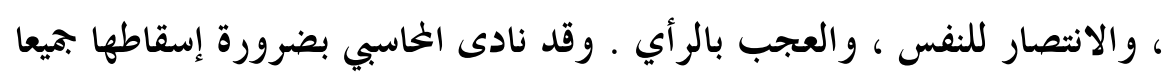

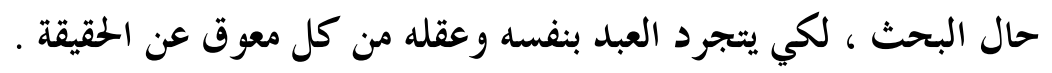
צ- عدم التسرع في إصدار الأحكام إلا بعد تبين كامل الحقائق . -V مراقبة الله تعلى بنية وإرادة صادقتين عند العلم والعمل وسيلة أكيدة للوصول

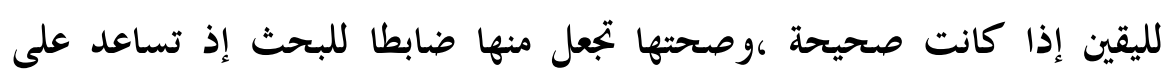

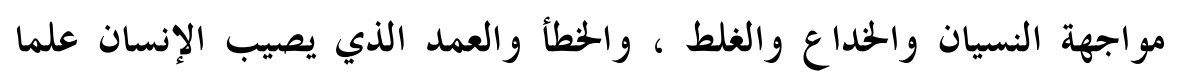
وعملا 1- الاعتبار وسيلة للاستدلال على المعرفة ، وهو كذلك وسيلة لزيادقا ، والمعتبر (VTY) 


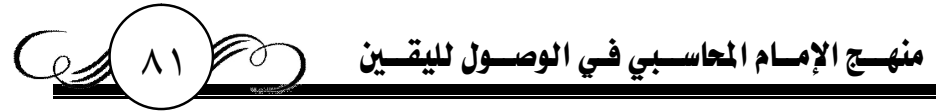

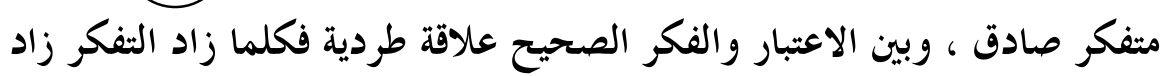

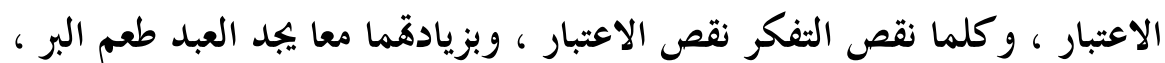

$$
\text { وبرد اليقين ، وروح الحكمة . }
$$

9- بعد الشك في المعارف وإسقاط الهوى ، لابد من النظر مرة أخرى في المعرفة المراد

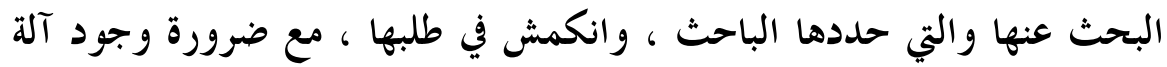

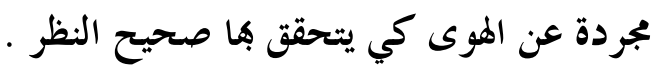

• 1- العقل هو آلة المعرفة التي تصدر عنه ، وهو حجة الله تعلى على العباد ، الذي جعله الله تعالى في الانسان معقل العلم ، ومستنبط الفهم ، وبه يتم الاستدلال.

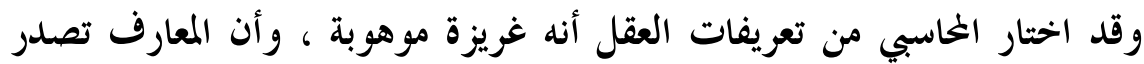

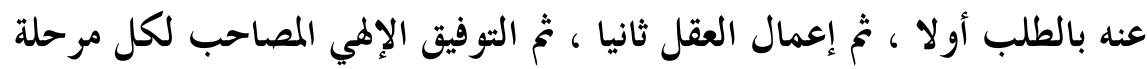
في النظر العقلي ، وبه يصل العبد للمعرفة الحقيقية ، وهو الذي سماه الخاسبي بعقل

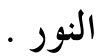

11- لا يصل العبد إلى اليقين إلا بحسن النظر ولا يتم ذلك إلا بتجريد العقل وإسقاط

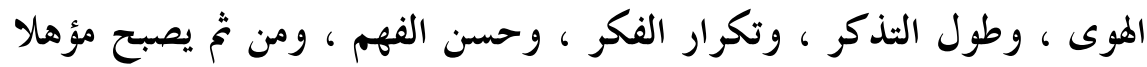

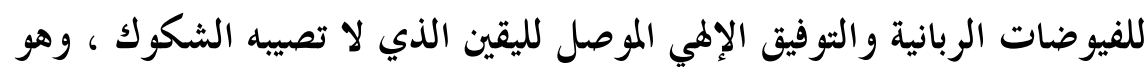

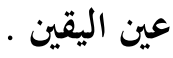

r ا - أثناء البحث عن اليقين ، واستخدام النظر العقلي يستصحب الباحث عددا من

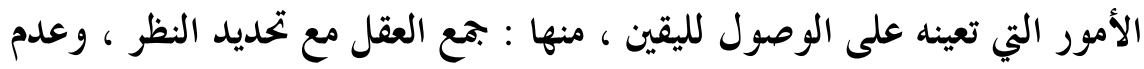

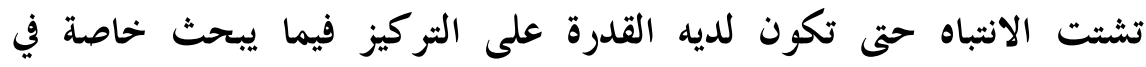

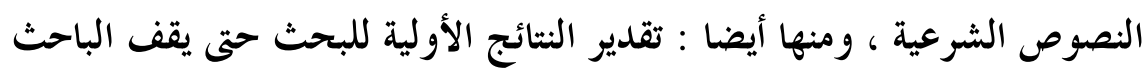

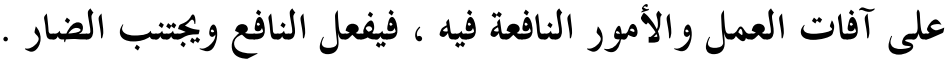

با - - ينبغي على الباحث عن الحقيقة في أي علم أو فن من الفنون أن يعرف قواعد كل (VTV) 


\section{منهـج الإمسام المحاسببي في الوصسول لليقسين}

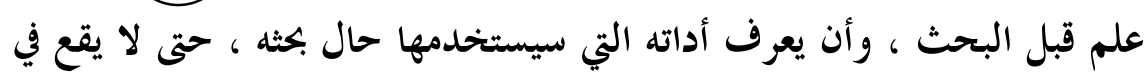

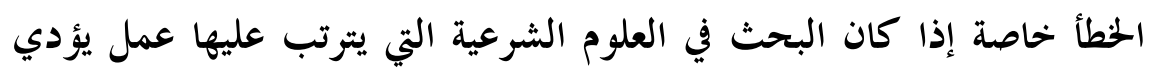

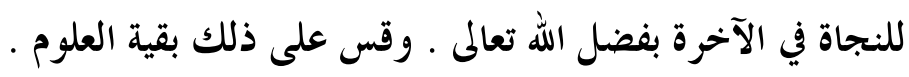

ع ا- يرى الإمام الخاسبي ضرورة الاستقراء التام أو ما سماه بالاستقصاء لجميع أفراد

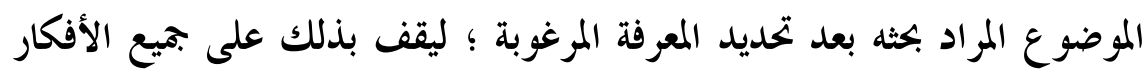

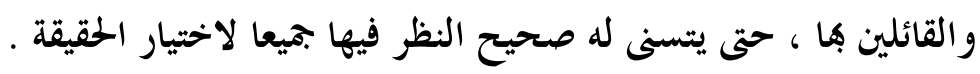

ه - تعد التجربة خير وسيلة للوصول اليقين وتثبيته ، وليس مجرد التجربة هو المقصود

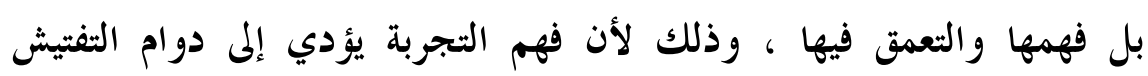

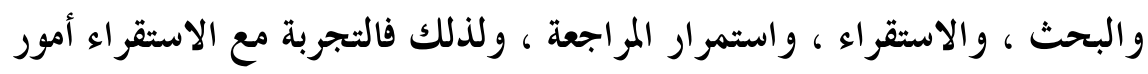

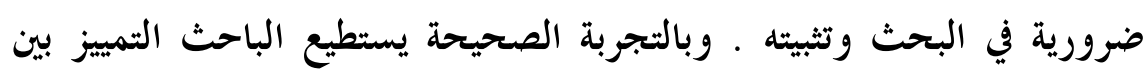

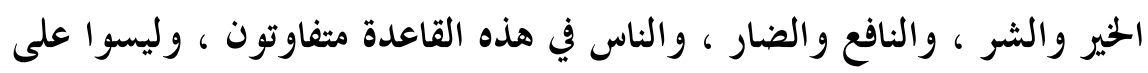

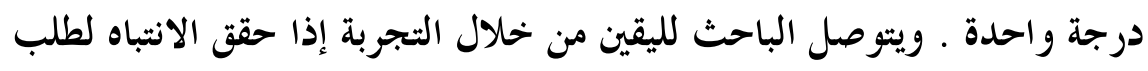

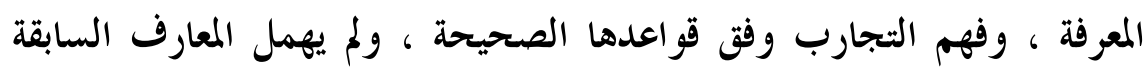
ليستفيد منها في عملية التمييز ، وهو ما يعرف بــــ ( تراكمية المعرفة ) .

17 - بعد انتهاء مرحلة الشك القائم على النظر الجزد ، وتصحيح آلة المعرفة لتحقيق

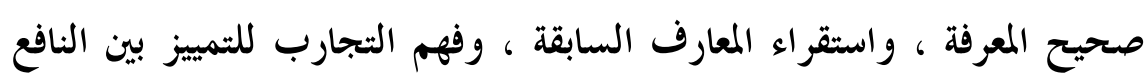

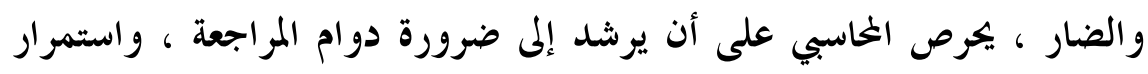

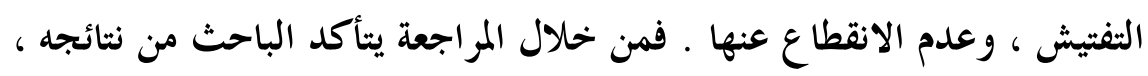

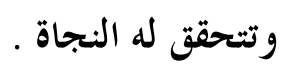

IV

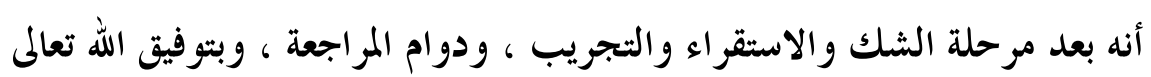
هداه الله تعلى إلى أناس عرف فيهم شيمة المثقين ، فاتبع سبيلهم ، وأدام مجالستهم 
منهـج الإمسام المحاسببي في الوصـول لليقسين

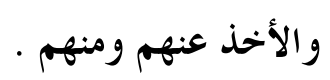

11 - من الأمور المهمة التي توصل إليها الإمام الخاسبي في بكثه عن اليقين :

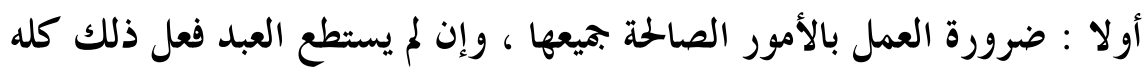

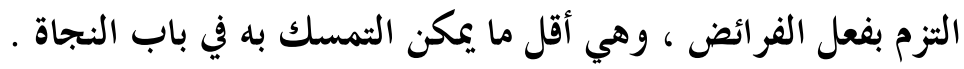

ثانيا : التحذير من النظر في الاختلاف ، وهي من أهم النتائج التي طبقها الخاسبي

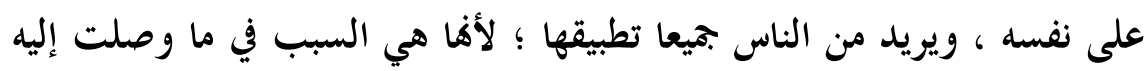

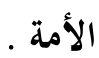

ثالثا : العمل على اليقين وترك الشكوك : وهذه النتيجة لابد منها بعد الوصول

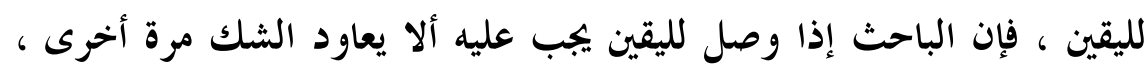

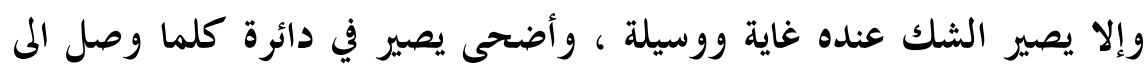

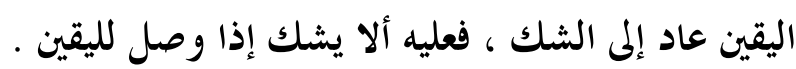

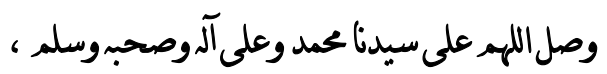
وسلار على المرسلين ، والحمد لله وب العلمين . 


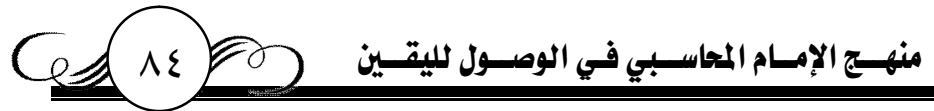

\section{قائمهلة بالمصـادر وأهــم المراجـع}

أ - - القرآنالكريه

\section{ب -السنة|النبوية}

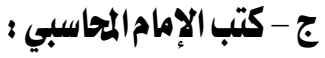

ا- آداب النفوس : الإمام الخاسبي . تحقيق : عبدالقادر أحد عطا ـ مؤسسة الكتب

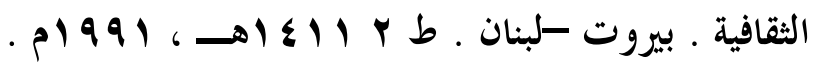

Y- الخلوة والتنقل في درجات العابدين : الإمام الخاسبي . تحقيق : إغناطيوس عبده خليفة . مجلة المشرق .عدد رقم ع أكتوبر 900 19 م ـ المطبعة الكاثوليكية . ب- رسالة المسترشدين : الإمام الخاسبي . تحقيق : عبدالفتاح أبو غدة . دار السلام .

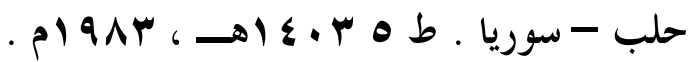

ع- الرعاية لحقوق الله: الإمام الخاسبي : تحقيق : عبدالقادر احد عطا ـدار الكتب العلمية. بيروت - لبنان . بلدون تاريخ .

ه- شرح المعرفة وبذل النصيحة : الإمام الخاسبي :. تحقيق : مجدي فتحي السيد . دار

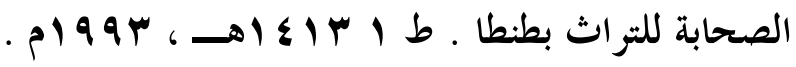

צ- فهم القرآن: الإمام الخاسبي . تحقيق : حسين القوتلي . دار الفكر . بيروت -

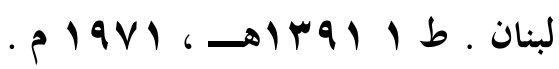

- القصد و الرجوع إلى الله تعالى .ضمن كتاب الوصايا : الإمام الخاسبي تحقيق :

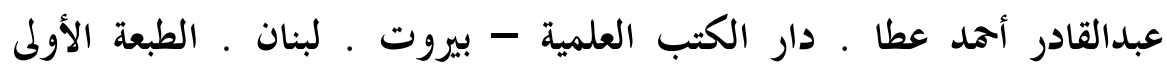

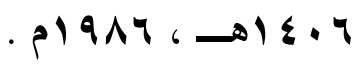

1 - مائية العقل الإمام الخاسبي : تحقيق : حسين القوتلي . دار الفكر . بيروت $(v \leq \cdot)$ 


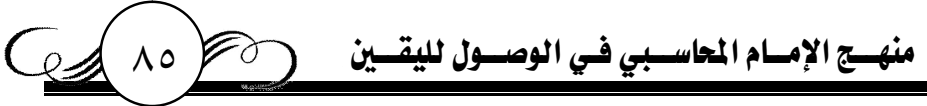

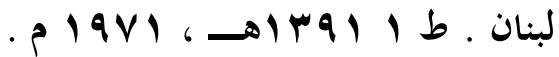

9- المكاسب. الإمام الخاسبي . تحقيق : عبدالقادر أحد عطا ـ مؤسسة الكتب الثقافية

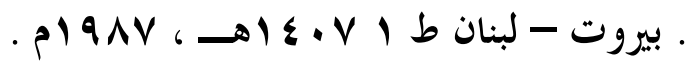

• 1 - النصائح. ضمن بجموع كتاب الوصايا : الإمام الخاسبي . تحقيق : عبدالقادر أحد

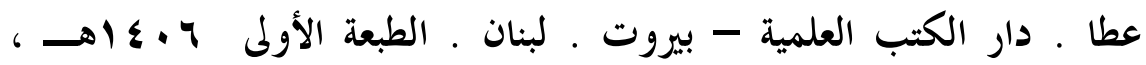

$$
\text { ? } 9 \wedge 7
$$

\section{د - م - مائمة بأهم المراجع}

1 | إحياء علوم الدين . الإمام أبو حامد الغزالي. دار المعرفة ـ بيروت -لبنان ـ بدون

$$
\text { · تاريخ }
$$

r ا أستاذ السائرين : الإمام الأكبر د/ عبدالحليم محمود ـ دار المعارف ـ القاهرة .

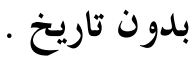

با - الأعلام : خير الدين الزركلي. دار العلم للملايين . بيروت - لبنان . طه ، $\cdot \rho 19 \Lambda$.

ع ا - الأورجانون الجديد : فرنسيس بيكون . ترجمة د/ عادل مصطفى ـ رؤية للنشر

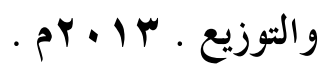

ه - تاريخ بغداد. الحطيب البغدادي . دار الكتب العلمية . بيروت -لبنان . צ ا - التعريفات : علي بن محمد الجرجاني . تحقيق : إبراهيم الإبياري . دار الكتاب

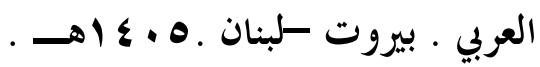

IV - التنبيه والرد على أهل الأهواء و البدع . أبو الحسين الملطي ـ تحقيق الثيخ محمد

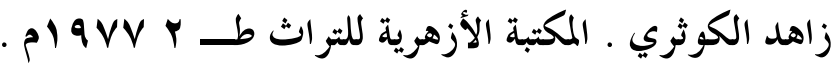




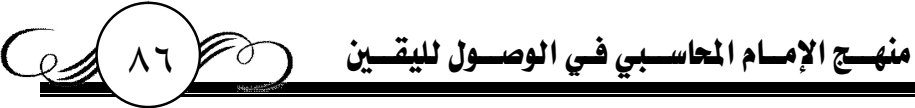

1 ا- تذيب الكمال : أبو الحجاج المزي :. تحقيق : د/ بشار معروف . مؤسسة

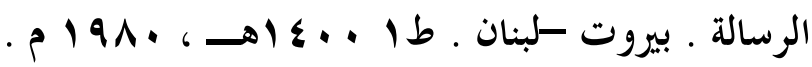

9 1 - التوقيف على مهام التعاريف : محمد عبدالرؤف المناوي تحقيق : محمد رضوان

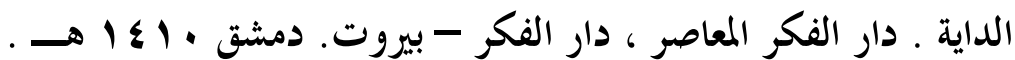
• • حلية الأولياء : أبو نعيم الأصبهاني : دار الكتاب العربي ـ بيروت - لبنان . ط \& ا Y - سنن ابن ماجة . تحقيق د / عحمد فؤ اد عبدالباقي ـ دار الفكر ـ بيروت -لبنان r r - طبقات الشافعية الكبرى : تاج الدين السبكي . تحقيق : د/ محمود محمد الطناحي

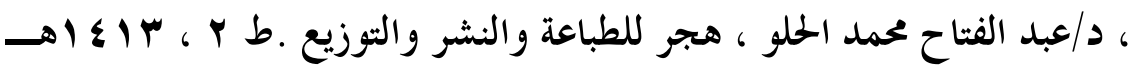

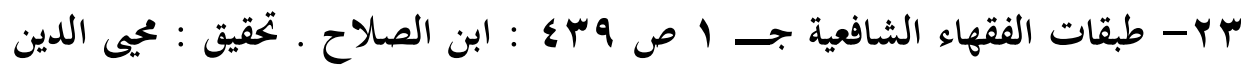

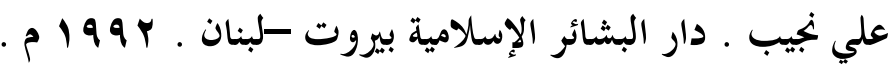

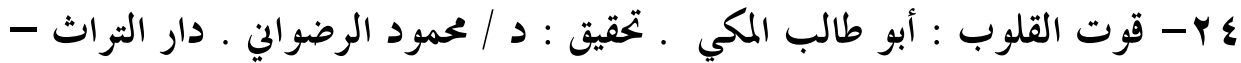

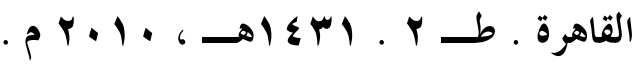
هץ - لسان العرب : ابن منظور دار صادر ـ بيروت .لبنان . צ - معالم أصول الدين : الفخر الرازي . تحقيق : طه عبدالرؤف سعد . دار الكتاب العربي · بيروت - لبنان . بدون تاريخ . لمبرت

- PV

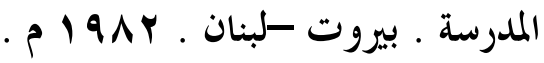

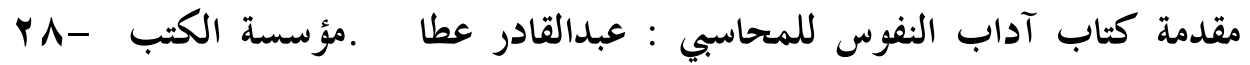

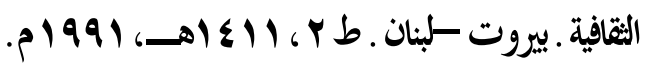




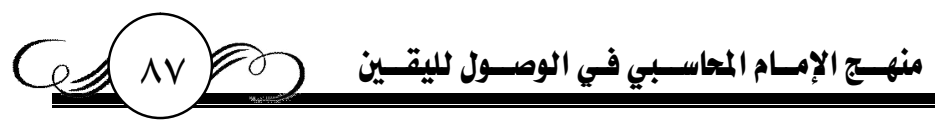 فهرس الموضـــــوعات}

$r$

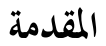

9

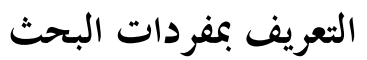

$\checkmark$ أولا : التعريف بالحارث الخاسبي

10 ثانيا : التعريف باليقين IV تعريف اليقين عند الإمام الخاسبي $r \cdot$ منهج الإمام الخاسبي في تحقيق اليقين . المرحلة الأولى : الشك القائم على النظر الجزد . .......................................... rq.

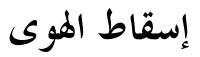
$\varepsilon \cdot$ المرحلة الثانية : تجريد آلة المعرفة

\&) تعريف العقل ، وكيفية تحقيق المعرفة .

0 .

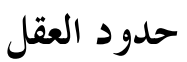

๑. أقسام العقلاء :

or أقسام العقل عند الخحاسبي.

09 المرحلة الثالثة : الاستقراء والتجربة 09 فهم التجربة.

Tร تطبيق قاعدة فهم التجربة IV المرحلة الر ابعة : إعلان نتائج البحث 


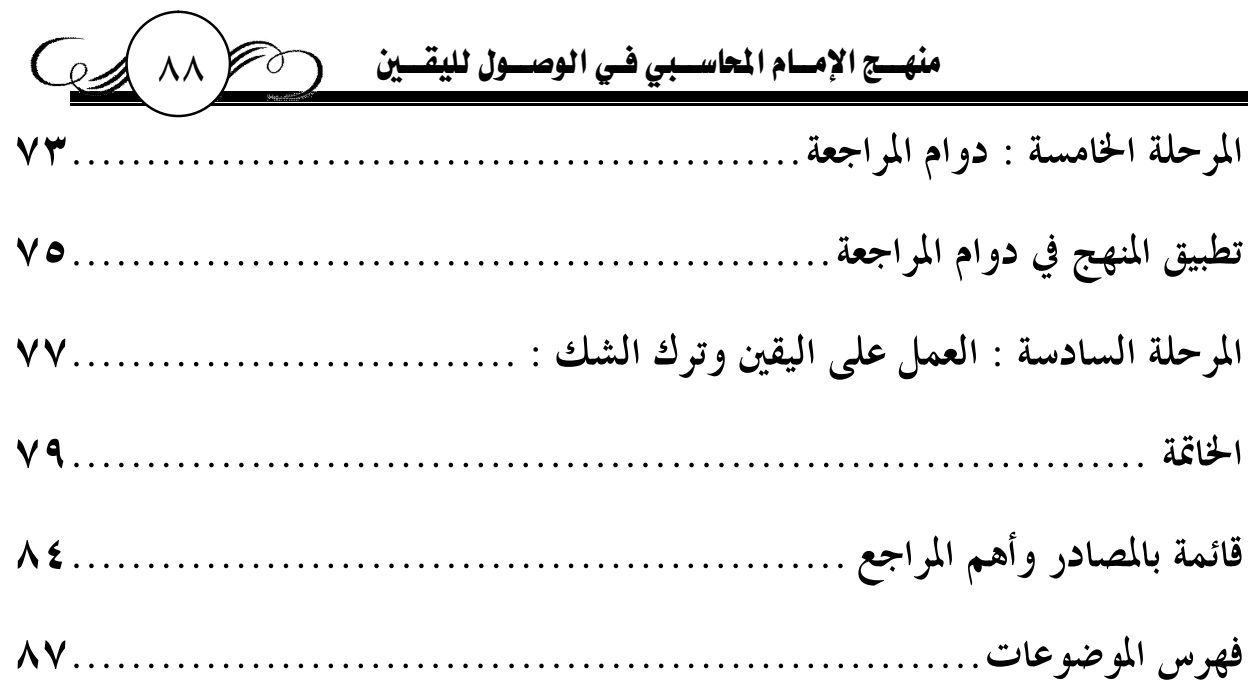

